\title{
Cool roofs in China: Policy review, building simulations, and proof-of-concept experiments
}

Yafeng $\mathrm{GAO}^{\mathrm{a}}$, Jiangmin $X \mathrm{U}^{\mathrm{a}}$, Shichao $\mathrm{YANG}^{\mathrm{b}}$, Xiaomin $\mathrm{TANG}^{\mathrm{a}}$, Quan ZHOU ${ }^{\mathrm{b}}$, Jing $\mathrm{GE}^{\mathrm{c}}$, TengFang $\mathrm{XU}^{\mathrm{c}}$, Ronnen LEVINSON ${ }^{\mathrm{c}^{*}}$

a Key Laboratory of the Three Gorges Reservoir Region's Eco-Environment, Ministry of Education, Faculty of Urban Construction and Environmental Engineering, Chongqing University, 400044, Chongqing, PR China

${ }^{b}$ Guangdong Province Academy of Building Research, 510500, Guangzhou, PR China

c Lawrence Berkeley National Laboratory, Berkeley, California, USA

* Corresponding author (RML27@cornell.edu; tel. +1-510-486-7494; Lawrence Berkeley National Laboratory, 1 Cyclotron Road, MS 90R2000, Berkeley, CA 94720, USA)

\section{Abstract}

While the concept of reflective roofing is not new to China, most Chinese cool roof research has taken place within the past decade. Some national and local Chinese building energy efficiency standards credit or recommend, but do not require, cool roofs or walls. EnergyPlus simulations of standard-compliant Chinese office and residential building prototypes in seven Chinese cities (Harbin, Changchun, Beijing, Chongqing, Shanghai, Wuhan, and Guangzhou) showed that substituting an aged white roof (albedo 0.6) for an aged gray roof yields positive annual load, energy, cost, $\mathrm{CO}_{2}$ savings, $\mathrm{NO}_{\times}$, and $\mathrm{SO}_{2}$ savings in all hot-summer cities (Chongqing, Shanghai, Wuhan, and Guangzhou).

Measurements in an office building in Chongqing in August 2012 found that a white coating lowered roof surface temperature by about $20^{\circ} \mathrm{C}$, and reduced daily air 


\section{Do not use graphics embedded in this document}

conditioning energy use by about $9 \%$. Measurements in a naturally ventilated factory in Guangdong Province showed that a white coating decreased roof surface temperature by about $17^{\circ} \mathrm{C}$, lowered room air temperature by $1-3^{\circ} \mathrm{C}$, and reduced daily roof heat flux by $66 \%$.

Simulation and experimental results suggest that cool roofs should be credited or prescribed in building energy efficiency standards for both hot summer/warm winter and hot summer/cold winter climates in China.

Keywords: cool roofs; China; building energy efficiency standards; energy savings; emission reductions

\section{Introduction}

China surpassed the United States in 2010 to become the world's largest energy consumer, and accounted for $71 \%$ of global energy consumption growth in 2011 (BP 2012). China's energy mix is carbon intensive, using coal to supply $71 \%$ of the 85 quadrillion BTU (90 EJ) it consumed in 2008. The U.S. Energy Information Administration predicts that China's electricity generation will increase to 10.5 trillion kWh by 2035, over triple the production in 2009 (US EIA 2012).

Facing challenges of energy security, global climate change, and environmental pollution, China has prioritized renewable energy and energy efficiency. In The Twelfth Five-Year Plan for National Economic and Social Development of the People's Republic of China released in July 2012, the government set year-2015 targets of reducing 


\section{Do not use graphics embedded in this document}

energy consumption per capital GDP by $16 \%, \mathrm{CO}_{2}$ emission per capital GDP by $17 \%$, national emission of $\mathrm{SO}_{2}$ by $8 \%$, and national emission of $\mathrm{NO}_{x}$ by $10 \%$ (CG 2011).

Improving building energy efficiency is an important element of the government's strategy for saving energy (CG 2011). In 2008, Chinese buildings consumed 655 Mtce (million tonnes coal equivalent) (20 EJ), accounting for about $23 \%$ of national energy use (TUBEEC 2011). Air conditioning was responsible for $11.2 \%$ of annual energy use in residential buildings in 2008 (TUBEEC 2011), and $18.8 \%$ of annual energy use in public buildings in 2005 (TUBEEC 2010).

One way to raise building energy efficiency is to select a 'cool' roof with high solar reflectance (ability to reflect sunlight, spectrum 0.3-2.5 $\mu \mathrm{m}$ ) and high thermal emittance (ability to emit thermal radiation, spectrum 4-80 $\mu \mathrm{m}$ ). By minimizing solar absorption and maximizing net thermal emission, such a roof stays cooler under the sun, reducing heat flow into the building (Levinson et al. 2005). A cool roof on an air-conditioned building can save energy and reduce power-plant emissions of $\mathrm{CO}_{2}, \mathrm{SO}_{2}$, and $\mathrm{NO}_{\mathrm{x}}$ (Akbari et al. 1999; Levinson and Akbari 2010), while a cool roof on an unconditioned building can lower the indoor air temperature and improve indoor comfort (Synnefa et al. 2007). Cool surfaces, including roofs, walls, and pavements, can also lower outdoor air temperature, further reducing the need for air conditioning and slowing the temperature-dependent formation of smog (Rosenfeld et al. 1998). Finally, negative radiative forcing by cool roofs can cool the atmosphere, mitigating warming induced by greenhouse gases (Akbari et al. 2012). 


\section{Do not use graphics embedded in this document}

Choosing a cool roof instead of a standard roof can slightly increase the need for heating energy in cold weather (e.g., winter). However, winter penalties are often much smaller than summer savings (Levinson and Akbari 2010) because solar availability in cold latitudes is limited in winter. For example, the northern mainland U.S. (latitude $\geq$ $40^{\circ} \mathrm{N}$ ) receives about 3 to 5 times as much daily sunlight in summer as in winter (Levinson 2009).

Building construction in China's urban areas has surged over the past decade, increasing building stock footprint to 20.4 billion $\mathrm{m}^{2}$ by 2008 (TUBEEC 2010). This presents many opportunities to specify and apply the climate-appropriate use of energysaving cool roofing products when roof waterproofing is first installed and when it is replaced at the end of its $10-20$ year service life.

In 2010, the United States Department of Energy (DOE) and China's Ministry of Housing and Urban-Rural Development (MOHURD) formed the US-China Cool Roof Working Group to evaluate the potential benefits of cool roofs in China. In 2011, Lawrence Berkeley National Laboratory (Berkeley, California, USA) partnered with Chongqing University (Chongqing) and the Guangdong Provincial Academy of Building Research (Guangzhou) to further investigate cool roof science and policies within the US-China Clean Energy Research Center - Building Energy Efficiency (CERC-BEE) (CERC-BEE 2014).

\section{Methods}

Decades of progress in cool roof science, technology and policy have been summarized in articles reviewing cool roof materials (Santamouris et al. 2011), energy savings 


\section{Do not use graphics embedded in this document}

(Levinson et al. 2005; Akbari and Konopacki 2005), urban heat island mitigation (Santamouris 2012; Navigant 2009), global cooling (Akbari et al. 2012), standards (Akbari and Levinson 2008), and weathering (Berdahl et al. 2008; Sleiman et al. 2011, 2014).

The current study focuses on the annual conditioning (heating and cooling) energy savings attainable by reducing roof solar heat gain. First, it reviews roof reflectance requirements in current Chinese building energy efficiency standards. Next, it simulates the energy savings, cost savings, and emission reductions attainable in various Chinese climates by increasing the solar reflectance of roofs on code-compliant prototypes of office and residential buildings. Finally, as proofs of concept for cool roofs in China, it measures summer-day cooling energy savings after a white roof coating was applied over part of a Chongqing office building, and summer-day roof heat flux and room air temperature reductions after a white roof coating was applied to a naturally ventilated factory building in Foshan (near Guangzhou).

\subsection{Review of roof and wall requirements in Chinese building energy efficiency standards}

China has national, provincial, and-in some cities—municipal building energy efficiency standards. These standards usually have different provisions for residential and public (nonresidential) buildings. To better understand how cool roofs (and walls) are treated, we reviewed national, provincial, and municipal standards, seeking language prescribing, crediting, or recommending the use of reflective or light-colored building envelope surfaces. 


\section{Do not use graphics embedded in this document}

\subsection{Cool roof simulations}

\subsubsection{Past research}

Cool roof savings and penalties have been simulated for many cities outside China. For example, annual heating savings and cooling penalties have been computed for building prototypes in hundreds of U.S. cities (Akbari et al. 1999; Akbari and Konopacki 2005; Levinson and Akbari 2010; Parker et al. 1998); five Indian climate zones (Bhatia et al. 2011); eight provinces in Andalucía and 49 cities in Spain (Boixo et al. 2012); and 27 world cities (Synnefa et al. 2007). Most studies also calculate energy cost savings based on local energy prices, and some also report emission reductions based on local emission factors. For example, Levinson and Akbari (2010) found that the average annual cooling site energy savings per unit conditioned roof area for the U.S.

commercial building stock was $5.0 \mathrm{kWh} / \mathrm{m}^{2}$, with annual heating site energy penalty 1.9 $\mathrm{kWh} / \mathrm{m}^{2}\left(0.065\right.$ therm $\left./ \mathrm{m}^{2}\right)$, annual energy cost savings $\$ 0.36 / \mathrm{m}^{2}$, and annual emission reductions of $3.0 \mathrm{~kg} \mathrm{CO} / \mathrm{m}^{2}, 4.8 \mathrm{~g} \mathrm{NO}_{\mathrm{x}} / \mathrm{m}^{2}, 12 \mathrm{~g} \mathrm{SO}_{2} / \mathrm{m}^{2}$, and $61 \mu \mathrm{g} \mathrm{Hg} / \mathrm{m}^{2}$.

No comparable analyses of cool roof savings and penalties across China were found in the literature. To fill this gap, the current study simulates energy savings, energy cost savings, and emission reductions attainable in various Chinese climates by increasing the solar reflectance of roofs on code-compliant prototypes of office and residential buildings. 


\section{Do not use graphics embedded in this document}

\subsubsection{Overview of simulations in current study}

The annual heating and cooling loads of a prototype office building and a prototype residential building were simulated in five representative Chinese climates with three different levels of roof albedo. Heating load savings (negative) and cooling load savings (positive) were calculated by subtracting heating and cooling energy uses with high roof albedo from those with low roof albedo. Load savings were then used to compute site energy savings, source energy savings, energy cost savings, and emission reductions. Results for seven selected Chinese cities in five Chinese climates zones are then compared to those in U.S. cities with similar climates.

\subsubsection{Prototype design}

Prototypes of the top floor of an office building (Figure A-1) and the top floor of a residential apartment building (Figure A-2) were assigned envelope characteristics, ventilation and infiltration rates, internal loads, operating schedules, and cooling and heating setpoints compliant with prescriptive requirements or recommended design values in current Chinese building energy efficiency standards. Table 1 details each prototype, hereafter denoted "office" and "residence" for brevity.

Note that while these prototypes should be typical of current Chinese construction, no single prototype can represent all buildings in its class. Hence, savings for a specific building may differ from those computed here. 


\section{Do not use graphics embedded in this document}

\subsubsection{Modeling heating and cooling loads}

The annual heating and cooling energy loads (heat energy per unit roof area) of each prototype were simulated with version 3.0.0.105 of DesignBuilder, a front end to the EnergyPlus building energy model (EnergyPlusDLL-32 7.0.0.036). For simplicity, loads were calculated by conditioning each building with ideal sources and sinks of heat (district heating and cooling).

Each prototype was modeled with three different roof albedos, representing a new white roof $(\rho=0.8)$, an aged white roof $(\rho=0.6)$, and an aged gray roof $(\rho=0.2)$, respectively. ${ }^{1}$ Simulations were performed in seven Chinese cities spanning five climate zones: severe cold A, severe cold B, cold, hot summer and cold winter, and hot summer and warm winter (Figure 1). Figure 3 and Table B-1 compare mean solar irradiance, heating degree days, cooling degree days, heating hour insolation, and cooling hour insolation ${ }^{2}$ in Harbin, Changchun, Beijing, Chongqing, Shanghai, Wuhan, and Guangzhou.

\subsubsection{Calculating cool-roof savings}

Cool roof annual cooling energy savings and heating energy penalties that result from reduction in radiative heat gain scale with roof area, rather than with floor area, because (a) only the roof intercepts sunlight and (b) there is practically no heat flow between levels in a multistory building conditioned to a uniform temperature. Furthermore,

\footnotetext{
${ }^{1}$ Soiling and weathering typically reduce the albedo of a white roof to about 0.6 from about 0.8 within a few years, while the albedo of a dark gray roof (about 0.2) is quite stable (Sleiman et al. 2011, 2014; Berdahl et al. 2008).

${ }^{2}$ Heating hour insolation, base $18^{\circ} \mathrm{C}(\mathrm{HHI} 18 \mathrm{C})$ is the sum of all insolation (incident solar radiation, $\mathrm{kWh} / \mathrm{m}^{2}$ ) received when the outside air dry-bulb temperature does not exceed $18^{\circ} \mathrm{C}$. Cooling hour insolation, base $18^{\circ} \mathrm{C}(\mathrm{CHI} 18 \mathrm{C})$ is the sum of all insolation received when the outside air dry-bulb temperature exceeds $18^{\circ} \mathrm{C}$.
} 


\section{Do not use graphics embedded in this document}

holding all else equal, fractional cooling energy savings and heating energy penalties increase with the ratio of roof area to building envelope area. Thus, cool roof load, energy, cost, and emission savings and penalties are reported as energy per unit conditioned roof area (CRA), where the denominator is defined as the horizontal roof area over conditioned space.

Cooling load savings and heating load savings (heat energy) were calculated by subtracting cooling and heating energy loads with a new or aged white roof from those with an aged gray roof. While both new white and aged white roofs were simulated to verify that the heating and cooling load savings scale linearly with albedo increase (0.6 for the new white roof, 0.4 for the aged white roof), the site energy, source energy, energy cost, and emission savings reported in this paper are based on the performance of an aged white roof, rather than a new white roof.

Heating and cooling site energy savings were computed by dividing the heating and cooling load savings by building and location appropriate heating and cooling efficiencies (Table 3). In severe cold and cold locations (Harbin, Changchun, and Beijing), the office was assigned coal heating and split-system electric cooling, while the residence was heated with coal and not cooled. In the hot-summer locations (Chongqing, Shanghai, Wuhan, and Guangzhou), both office and residence were assumed to use split-system electric heating and cooling.

Heating and cooling source energy savings were calculated by multiplying each site energy savings by the appropriate source-to-site ratio ( $f=3.147$ for electricity, 1.05 for coal), and then summed to yield source conditioning (heating plus cooling) energy 


\section{Do not use graphics embedded in this document}

savings. Likewise, heating and cooling energy costs savings (RMB per unit roof area) were computed by multiplying each site energy savings by the appropriate energy price (Table 5), and then summed to yield conditioning energy cost savings.

To calculate the present value (PV) of lifetime energy cost savings, we assume that the roof yield constant annual energy cost savings over its $N$ year service life. Then given a real (inflation-adjusted) annual rate of return $r$, the ratio of lifetime energy cost savings to annual energy cost savings is

$$
b=\sum_{i=1}^{N}(1+r)^{-i}=\left[1-(1+r)^{-N}\right] r .
$$

The PV multiplier $b$ increases with roof lifetime $N$ and decreases with real annual rate of return $r$ (Table 7).

Finally, reductions in $\mathrm{CO}_{2}, \mathrm{NO}_{x}$, and $\mathrm{SO}_{2}$ emissions from heating and cooling energy savings were calculated by multiplying heating and cooling site energy savings by the appropriate energy transmission factor ( 0.9 for electricity, 1 for coal) and pollutant emission factor (Table 9 and Table 11), and then summed to yield emission savings for each pollutant. Mercury emission reductions are not presented because China-specific electricity and coal mercury emission factors could not be identified.

\subsection{Cool roof experiments}

\subsubsection{Past research}

Cooling energy savings have been measured for buildings in several hot U.S. climates, including at least 10 commercial buildings in California (Konopacki et al. 1998; 


\section{Do not use graphics embedded in this document}

Hildebrandt et al. 1998) (Akbari et al. 2005); seven stores (Parker et al. 1997), nine homes (Parker and Barkaszi 1997), and a school (Parker et al. 1998) in Florida; a home in California (Rosado et al. 2013); and a store in Texas (Konopacki and Akbari 2001). Measured annual cooling energy savings ranged from about 0.6 to $6.4 \mathrm{kWh} / \mathrm{m}^{2}$ (Levinson et al. 2005). Cooling energy savings have also been measured in Hyderbad, India (Xu et al. 2012). Calibrated simulations have been used to estimate cool roof energy savings for specific buildings in Phoenix (Jo et al. 2010), Athens (Synnefa et al. 2012), India (Bhatia et al. 2011), Sicily (Romeo and Zinzi 2011), and London (Kolokotroni et al. 2011).

While the term "cool roof" is relatively new in China, the use of light-colored roofing and exterior wall materials has been studied and in practice there for several decades. Past work includes development of solar reflective materials and study of their effects on indoor air temperature and building energy use. In China, light-colored walls and roofs have long been treated as "heat insulation" measures in various design standards, because increasing surface reflectance and adding insulation can each reduce conduction of heat into a building (though by very different means). For example, in a guide to building indoor temperature reduction in hot weather, the China Academy of Building Research Architectural Design Institute (CABRADI 1965) noted that lightcolored exterior coatings could decrease the solar heat gain and surface temperatures of walls by reflecting sunlight, thereby cooling the building.

Wang (2007) at Henan University of Technology measured the ability of reflective roofing to reduce air and grain temperatures in naturally ventilated grain storage house in Linqing, Shangdong Province. The original roof was $30 \mathrm{~mm}$ of concrete, covered by 


\section{Do not use graphics embedded in this document}

$80 \mathrm{~mm}$ of perlite board insulation and surfaced with a maroon-color modified bitumen cap sheet. From June to August 2003, $50 \mathrm{~mm}$ of rigid polyurethane foam and $0.8 \mathrm{~mm}$ of acrylic coating surfaced with aluminum foil were added to the original roof, reducing inside air temperature by up to $5 \mathrm{~K}$, and lowering grain temperature by up to $3-4 \mathrm{~K}$. In another trial at this site, the roof was covered with bare aluminum foil, reducing indoor air temperature by $2.5 \mathrm{~K}$, and lowering grain temperature by $2 \mathrm{~K}$.

In a collaboration between Tongji University and the Miki Coating Design Office in Japan, Shen et al. (2007) compared the temperatures of light and dark-colored roofs on a naturally ventilated factory building in Guangzhou, Guangdong Province, in July 2007. Each roof was $0.5 \mathrm{~mm}$ of profiled steel over $5 \mathrm{~mm}$ of fiberglass insulation. The upper and lower surfaces of the light-colored roof (solar reflectance 0.42 ) were up to $6.8 \mathrm{~K}$ and 4.3 K cooler, respectively, than those of the dark-colored roof (solar reflectance 0.27 ). Similarly, Yang et al. (2012) at the Guangdong Provincial Academy of Building Research compared the temperatures of light and dark-colored profiled steel roofs in Foshan, Guangdong Province, in August 2011. The upper and lower surfaces of lightcolored roof (solar reflectance 0.82 ) were 12 - $16 \mathrm{~K}$ and 5 - $7 \mathrm{~K}$ cooler, respectively, than those of the dark colored roof (solar reflectance 0.29 ). The indoor air temperature under the light-colored roof was 1 - $3 \mathrm{~K}$ lower than that under the dark roof. Further results from that study will be presented here.

Shen and Tan (2009) at Tongji University measured reduction in roof heat flux from application of a reflective roof coating to a naturally ventilated factory in Guangzhou. Increasing the roof's solar reflectance to 0.74 from 0.44 reduced measured monthly heat flux through the roof in summer (June - August 2009) by $17 \%-22 \%$. 


\section{Do not use graphics embedded in this document}

Jiang (2012) at Guangdong Provincial Academy of Building Research measured the effects of solar reflectance on the roof temperature and building cooling energy use of an air-conditioned dormitory building in Guangzhou. This building has a $120 \mathrm{~mm}$ reinforced concrete roof, covered with $30 \mathrm{~mm}$ of expanded polystyrene foam insulation and surfaced with $40 \mathrm{~mm}$ of crushed stone concrete. In a side-by-side comparison, increasing roof solar reflectance to 0.82 from 0.18 reduced summer-afternoon surface temperature by $10-15 \mathrm{~K}$, and reduced daily cooling energy use by about $73 \mathrm{Wh}$ per $\mathrm{m}^{2}$ roof area.

\subsubsection{Proof-of-concept experiment in air-conditioned office building in Chongqing}

A white coating was applied to the roof of a top-floor room in an air-conditioned office building in the Shapingba district of Chongqing. Roof top, roof bottom, ceiling, and indoor air temperatures were compared between the top-floor room with white-coated roof and its adjacent room with uncoated roofs. Cooling energy uses were also compared on days when both rooms were air conditioned.

In May 2012, a white elastomeric coating was applied to the roof section over room 510 in the top floor of an occupied office building at Chongqing University. The roof over adjacent room 512 was uncoated and remained black (Figure 5). Each room has its own split-system air conditioner, which can be turned on to measure cooling energy savings, or left off to measure room air temperature reduction. The geometry, construction, cooling equipment, and cooling schedule of each room and its roof are detailed in Table 13. Both rooms have similar occupancy. 


\section{Do not use graphics embedded in this document}

Roof top, roof bottom, and ceiling temperatures were measured with a handheld infrared thermometer, while indoor air temperatures were measured both handheld and fixed sensors. Rooftop solar irradiance was measured with a first-class pyranometer, and cooling electricity use was measured with a power meter (Table 15; Figure 7). Concurrent outside air temperature was obtained from a weather station $1.3 \mathrm{~km}$ away (104 Yinshui Cun, Shapingba district, Chongqing).

Several full-day measurements were conducted in August 2012 to compare the roof temperatures, room temperatures, and (when the rooms were air conditioned) cooling energy uses of the adjacent white- and black-roofed rooms. Two daily results are reported here: one on August 14 (air conditioners on), and another on August 17 (air conditioners off).

\subsubsection{Proof-of-concept experiment in naturally ventilated factory in Foshan}

A white coating was applied to part of the metal roof of a single-story, naturally ventilated factory building in Foshan, Guangdong Province (near Guangzhou). Roof top, roof bottom, and indoor air temperatures were compared for adjacent rooms with white and non-white roofs. Roof heat fluxes were computed from roof temperature profiles.

In August 2011, a white elastomeric coating (with initial albedo of 0.8 ) was applied to the metal roof over one room in the factory, while the metal roof over a neighboring room remained blue (albedo 0.3 ) (Figure 9). The geometry and construction of each room and its roof are detailed in Table 17. 


\section{Do not use graphics embedded in this document}

Roof top, roof bottom, and room air temperatures were measured with thermocouples continuously, while rooftop solar irradiance was measured with a first-class pyranometer (Table 19). All measurements were logged and recorded every 5 minutes. Heat flux through each roof was computed by dividing the temperature difference between roof top and room bottom by the thermal resistance of the roof.

The continuous monitoring lasted for 5 days (August $27-31,2011$ ). We detail results for one typical day, and also characterize the average heat fluxes over entire the 5-day trial.

\section{Results and discussion}

\subsection{Roof and wall provisions in Chinese building energy efficiency standards}

In the early 1980s, China quantified average building energy use, and now uses these values as a reference to develop new public and residential building standards. The 1980s study also specified the thermal transmittance ${ }^{3}$ of building envelope components in representative cities, and the efficiency of heating and cooling equipment. Lightcolored surfaces were recognized as a "heat insulation" measure in Chinese standards as early as 1993. For example, Section 5.2.1 of Design Standard for Residential Building Thermal Performance GB 50176-1993 (MOHURD 1993) specifies that building envelope heat insulation measures could include light-colored exterior surfaces. The

\footnotetext{
${ }^{3}$ Chinese energy efficiency standards use the term "heat transfer coefficient" and the symbol $K$ to describe the ratio of the heat flux per unit area through the envelope to the air temperature difference across the envelope. Here we use the Western nomenclature "thermal transmittance" and symbol $U$ for this property to avoid potential confusion with (a) convective and radiative surface heat transfer coefficients and (b) thermal conductivity.
} 


\section{Do not use graphics embedded in this document}

standard includes solar absorptance of exterior surfaces of building envelope in calculation of indoor air temperature.

Current residential and public building standards seek to realize substantial energy savings relative to the 1980 s-era standards (e.g., by $50 \%$ or $65 \%$ ). National standards include three for residential buildings (each covering a different climate or set of climates) and one for public buildings (Table 21). Figure 1 shows the five Chinese climate zones—hot summer \& warm winter, hot summer \& cold winter, temperate, cold, and severe cold—referenced by these national standards. Heating and cooling degree days are used to subdivide the cold zone into cold $A$ and $B$, and to subdivide the severe cold zone into severe cold A, B and C.

Chinese building energy efficiency standards permit both prescriptive (checklist) and performance (energy budget) compliance. Current national standards credit the use of cool roofs only on residential buildings in the hot summer/warm winter climate, though they recommend the use of cool surfaces on some other buildings (Table 21). While there is no recommendation or credit for cool surfaces in the current national standard on public buildings, the current "Evaluation Standard for Green Building GB/T 503782006 " encourages use of vegetation on roofs or exterior surfaces for public buildings (MOHURD 2006).

The local standard in Chongqing (hot summer \& cold winter) credits the use of lightcolored walls on residential buildings; furthermore, the local standard in Shanghai (hot summer \& cold winter) also credit the use of high-albedo surfaces for both roofs and walls on residential buildings. In addition, the local standard in Hainan (hot summer \& 


\section{Do not use graphics embedded in this document}

warm winter) credits the use of cool roofs on residential buildings, while Yunnan's provincial standard only recommends cool exterior surface, roof vegetation, and roof shading for buildings in temperate climates (Table 23).

Local standards in Shanghai (hot summer \& cold winter) credit the use of high solar reflectance roofs and walls on public buildings, while the local standard in Chongqing (hot summer \& cold winter) recommends, but does not credit, the use of light-colored walls and roofs on public buildings. Similarly, Jiangsu provincial standard recommends but does not credit the use of roof plants for flat roofs on public buildings (hot summer \& cold winter) (Table 25). Surprisingly, there is no credit or recommendation for cool roof in the Hainan provincial standard on public buildings (hot summer \& warm winter).

The Compulsory Provisions of Engineering Construction Standards (MOHURD 2002) specifies that for light roofs with thermal inertia ${ }^{4}$ less than 2.5 (e.g., metal roofs), it is mandatory to apply cool roofs (e.g., light-colored surfaces with low solar absorptance and high thermal emittance).

\subsubsection{Discussion}

Our review of roof and wall requirements in Chinese building energy efficiency standards indicates that only some of the latest Chinese energy efficiency standards for hot-summer climates address the use of cool roofs or walls. Credits (if any) for cool surfaces in China's national and local standards typically take the form of added thermal resistance or reduced thermal transmittance of the building envelope. These credits are

\footnotetext{
${ }^{4}$ Chinese standards define thermal inertia $D$ as the product of thermal resistance $R$ and a vaguely described "coefficient of thermal storage" $S$.
} 


\section{Do not use graphics embedded in this document}

analogous to those offered a decade ago for warm climates (zones $1-3)$ in U.S. building energy efficiency standard ASHRAE 90.1-2004 (ASHRAE 2004). The current version of this U.S. standard (ASHRAE 90.1-2010) has since replaced the cool roof credit with a cool roof prescription (ASHRAE 2010).

\subsection{Cool roof simulations}

\subsubsection{Heating, cooling, and conditioning load savings}

Heating and cooling load savings scaled linearly with increase in roof albedo (Figure 11), as demonstrated previously in U.S. cool roof simulations by Konopacki et al. (1997).

Increasing roof albedo to 0.6 (aged white roof) from 0.2 (aged gray roof) increased the annual heating load of the office by $1.0 \mathrm{kWh} / \mathrm{m}^{2}$ (Chongqing) to $4.2 \mathrm{kWh} / \mathrm{m}^{2}$ (Changchun), while reducing its annual cooling load by $2.3 \mathrm{kWh} / \mathrm{m}^{2}$ (Harbin) to 12.4 $\mathrm{kWh} / \mathrm{m}^{2}$ (Guangzhou) (Figure 13a). Annual conditioning (heating plus cooling) load savings ranged from $-1.5 \mathrm{kWh} / \mathrm{m}^{2}$ (Changchun) to $10.5 \mathrm{kWh} / \mathrm{m}^{2}$ (Guangzhou), and were positive everywhere but Harbin and Changchun (Figure 15a).

In the residence, the annual heating load increases ranged from $0.2 \mathrm{kWh} / \mathrm{m}^{2}$ (Guangzhou) to $4.7 \mathrm{kWh} / \mathrm{m}^{2}$ (Shanghai), while the cooling load reduction ranged from zero (in Harbin and Changchun, where the residential building was not cooled) to 10.9 $\mathrm{kWh} / \mathrm{m}^{2}$ (Guangzhou) (Figure 13b). annual conditioning load savings ranged from -2.2 $\mathrm{kWh} / \mathrm{m}^{2}$ (Changchun) to $10.7 \mathrm{kWh} / \mathrm{m}^{2}$ (Guangzhou), and were positive in everywhere but Harbin and Changchun (Figure 15b). 


\section{Do not use graphics embedded in this document}

Simulated loads and load savings are further detailed in Table D-1 (office) and Table D-3 (residence).

\subsubsection{Site and source energy savings}

The cool roof increased the heating site energy use of the office by $0.3 \mathrm{kWh} / \mathrm{m}^{2}$ (Chongqing) to $6.0 \mathrm{kWh} / \mathrm{m}^{2}$ (Changchun), while reducing its cooling site energy use by $0.7 \mathrm{kWh} / \mathrm{m}^{2}$ (Harbin) to $3.8 \mathrm{kWh} / \mathrm{m}^{2}$ (Guangzhou). Heating source energy use increased by $0.9 \mathrm{kWh} / \mathrm{m}^{2}$ (Chongqing) to $6.2 \mathrm{kWh} / \mathrm{m}^{2}$ (Changchun), while cooling source energy use decreased by $2.2 \mathrm{kWh} / \mathrm{m}^{2}$ (Harbin) to $11.9 \mathrm{kWh} / \mathrm{m}^{2}$ (Guangzhou) (Figure 13a). Conditioning source energy savings ranged from $-3.7 \mathrm{kWh} / \mathrm{m}^{2}$ (Changchun) to 10.2 $\mathrm{kWh} / \mathrm{m}^{2}$ (Guangzhou), and were positive in all four hot-summer cities (Figure 15a).

In the residence, heating site energy use increased by $0.1 \mathrm{kWh} / \mathrm{m}^{2}$ (Guangzhou) to 3.8 $\mathrm{kWh} / \mathrm{m}^{2}$ (Beijing), while cooling site energy use decreased by zero (in Harbin and Changchun, where the residential building was not cooled) to $3.3 \mathrm{kWh} / \mathrm{m}^{2}$ (Guangzhou). Heating source energy use increased by $0.2 \mathrm{kWh} / \mathrm{m}^{2}$ (Guangzhou) to $4.3 \mathrm{kWh} / \mathrm{m}^{2}$ (Shanghai), while cooling source energy use decreased by zero (in Harbin and Changchun) to $10.5 \mathrm{kWh} / \mathrm{m}^{2}$ (Guangzhou) (Figure 13a). Conditioning source energy savings ranged from $-3.3 \mathrm{kWh} / \mathrm{m}^{2}$ (Changchun) to $10.3 \mathrm{kWh} / \mathrm{m}^{2}$ (Guangzhou), and were positive in all four hot-summer cities (Figure 15b).

Site and source energy savings are further detailed in Table D-5 (office) and Table D-7 (residence). 


\section{Do not use graphics embedded in this document}

\subsubsection{Energy cost and emission savings}

Energy cost savings in the office ranged from $-0.4 \mathrm{RMB} / \mathrm{m}^{2}$ (Harbin) to $3.3 \mathrm{RMB} / \mathrm{m}^{2}$ (Guangzhou) in the office, and from $-0.4 \mathrm{RMB} / \mathrm{m}^{2}$ (Harbin) to $2.0 \mathrm{RMB} / \mathrm{m}^{2}$ (Guangzhou) in the residence (Figure 15). Office energy cost savings were positive everywhere but Harbin, and while residence energy cost savings were positive everywhere but Harbin and Changchun. Note that residential energy cost savings were zero in Changchun, where there is no fuel charge for coal heating in either commercial or residential buildings, and residential buildings are not cooled.

$\mathrm{CO}_{2}$ emission savings ranged from $-1.0 \mathrm{~kg} / \mathrm{m}^{2}$ (Changchun) to $3.4 \mathrm{~kg} / \mathrm{m}^{2}$ (Guangzhou) in the office, and from $-1.0 \mathrm{~kg} / \mathrm{m}^{2}$ (Changchun) to $3.4 \mathrm{~kg} / \mathrm{m}^{2}$ (Guangzhou) in the residence; these savings were positive in all hot-summer cities. $\mathrm{NO}_{x}$ emission savings ranged from $0.8 \mathrm{~g} / \mathrm{m}^{2}$ (Harbin) to $13.2 \mathrm{~g} / \mathrm{m}^{2}$ (Guangzhou) in the office, and from -2.0 $\mathrm{g} / \mathrm{m}^{2}$ (Changchun) to $13.3 \mathrm{~g} / \mathrm{m}^{2}$ (Guangzhou) in the residence. Finally, $\mathrm{SO}_{2}$ emission savings ranged from $-10.5 \mathrm{~g} / \mathrm{m}^{2}$ (Changchun) to $32.6 \mathrm{~g} / \mathrm{m}^{2}$ (Guangzhou) in the office, and from $-8.6 \mathrm{~g} / \mathrm{m}^{2}$ (Changchun) to $32.8 \mathrm{~g} / \mathrm{m}^{2}$ (Guangzhou) in the residence (Figure 17). Note that while coal $\mathrm{CO}_{2}$ emission factors are independent of combustion system type and boiler firing configuration (US EIA 2011), the coal $\mathrm{NO}_{\mathrm{x}}$ and $\mathrm{SO}_{2}$ emission factors used here are for spreader stokers characterized by the US EPA (US EPA 1995), and may or may not represent building furnaces in China.

Energy cost and emission savings are further detailed in Table D-7 (office) and Table D-9 (residence). 


\section{Do not use graphics embedded in this document}

\subsubsection{Discussion}

The above results illustrate how location, its weather, building type and construction, and HVAC operating schedule collectively influence cool-roof heating and cooling load savings in China. Climate-specific HVAC choices (e.g., coal heating in colder cities, electric heating in warmer cities) then guide the conversion of load savings to energy and carbon savings. In addition, city and sector (commercial/residential) variations in the prices of electricity and coal influence energy cost savings, while variations in emission factors for different heating types affect pollution savings.

\subsubsection{Implications for Chinese building energy efficiency standards}

Cool roofs provided annual energy, cost, $\mathrm{CO}_{2}, \mathrm{NO}_{\mathrm{x}}$, and $\mathrm{SO}_{2}$ savings for both office and residential buildings in all four Chinese cities with hot summers (Chongqing, Shanghai, Wuhan, Guangzhou). This suggests that the use of cool roofs should be promoted in both public and residential building energy efficiency standards in hot-summer climates.

Simulation results in Beijing were mixed, with positive annual load, energy cost, $\mathrm{NO}_{\mathrm{x}}$, and $\mathrm{SO}_{2}$ savings, but slightly negative annual source energy and $\mathrm{CO}_{2}$ savings. Cool roofs are not recommended for Harbin and Changchun, where penalties generally outweighed savings.

\subsubsection{Heating and cooling hour insolations as predictors of heating and cooling load savings}

Assume that there is some value of outdoor air dry bulb temperature $T$ - say, $T_{0}=18^{\circ} \mathrm{C}-$ below which a building is likely to employ heating, and above which a building is likely to employ cooling. While heating and cooling loads that result from conduction, infiltration, 


\section{Do not use graphics embedded in this document}

and ventilation are expected to correlate with heating degree days (HDD, the time integral of the positive values of $\left.T_{0}-T\right)$ and cooling degree days (CDD, the time integral of the positive values of $T-T_{0}$ ), respectively, the heating and cooling load savings that result from changes in roof albedo are expected to scale instead with solar availability during heating and cooling hours, respectively. Simple weather-based metrics for these solar availabilities are heating hour insolation $(\mathrm{HHI}$, the time integral of solar irradiance when $\left.T \leq T_{0}\right)$ and cooling hour insolation $(\mathrm{CHI}$, the time integral of solar irradiance when $\left.T>T_{0}\right){ }^{5}$ To illustrate, consider the heating and cooling load savings in Chongqing, Shanghai, and Wuhan, where there are no differences in office envelope design or HVAC operating schedule among simulated offices, as well as no such differences among the simulated residences. The heating load penalty (additive inverse of heating load savings) varies monotonically with $\mathrm{HHI} 18 \mathrm{C}$, but not HDD18C, while the cooling load savings varies monotonically with $\mathrm{CHI18C}$, but not CDD18C (Figure 19).

Furthermore, the ratio of heating load penalty to cooling load saving roughly tracks the ratio of $\mathrm{HHI} 18 \mathrm{C}$ to $\mathrm{CHI} 18 \mathrm{C}$ (Figure 21).

\subsubsection{Comparing Chinese heating and cooling load savings to U.S. savings}

While the variation of heating hour insolation with heating degree days is similar in China and the U.S., the Chinese cities simulated generally receive less cooling hour insolation for equal cooling degree days (Figure 23). The heating load penalties and cooling load savings for office buildings in Harbin, Beijing, Shanghai, and Guangzhou were compared to those previously simulated for office prototypes with the same roof

\footnotetext{
${ }^{5}$ We have defined heating hour insolation with the criterion $T \leq T_{0}$ rather than $T<T_{0}$ to ensure that annual heating hour insolation + annual cooling hour insolation $=$ annual insolation.
} 


\section{Do not use graphics embedded in this document}

thermal transmittance and the same roof albedo change (increase to 0.6 from 0.2 ) in four U.S. cities: Duluth, MN (ASHRAE U.S. climate zone 7); Baltimore, MD (zone 4A); Atlanta, GA (zone 3A); and Las Vegas, NV (zone 3B-other). These U.S cities were chosen to approximate the heating and/or cooling degree days of their Chinese counterparts (Table 27 and Table 29). The heating and cooling load savings of the U.S. prototypes were derived from unpublished tables of heating and cooling site energy savings prepared by Akbari and Konopacki (2005).

Figure 25 compares the heating load penalties and cooling load savings of office buildings in China to those in the U.S. Each pair is plotted first with the Chinese savings as simulated, then again with the Chinese savings scaled by the ratio of the heating or cooling hour insolation in the U.S. to that in China (Table 29). Las Vegas/Guangzhou are omitted from the heating comparison because their HDD18C do not match, while Duluth/Harbin are excluded from the cooling comparison because their CDD18C do not match. Scaling generally improves matches in both heating load penalties and cooling load savings.

While the variation of heating hour insolation with heating degree days is similar in China and the U.S., the Chinese cities simulated generally receive less cooling hour insolation for equal cooling degree days. All else being equal, this reduction in coolingseason sunlight tends to make cool-roof cooling energy savings in Chinese cities smaller than those in U.S. cities with the same number of cooling degree days. 


\section{Do not use graphics embedded in this document}

\subsubsection{Influences of office building construction and HVAC operating schedule on load savings}

Office cooling load savings tend to increase as one moves from the coldest cities to the warmest cities (left to right in Figure 13) with the general rise in $\mathrm{CHI} 18 \mathrm{C}$ (Figure 3a) and the monotonic rise in roof thermal transmittance $U$ (Table 31). An interesting exception arises in the transition from Beijing $\left(\mathrm{CHI} 18 \mathrm{C}=799 \mathrm{kWh} / \mathrm{m}^{2}, \mathrm{U}=0.55 \mathrm{~W} \mathrm{~m}^{-2} \mathrm{~K}^{-1}\right)$ to Chongqing $\left(\mathrm{CHI} 18 \mathrm{C}=661 \mathrm{kWh} / \mathrm{m}^{2}, \mathrm{U}=0.70 \mathrm{~W} \mathrm{~m}^{-2} \mathrm{~K}^{-1}\right)$, where the decrease in $\mathrm{CH} 18 \mathrm{C}$ combines with the increase in $U$ to make the cooling load savings in Chongqing about $4 \%$ lower than in Beijing.

While office heating load penalties tend to be smaller in warm cities than in cold cities, the trend is far from monotonic because roof thermal transmittances are higher in warm cities. Chongqing is again an interesting case. The heating load penalty for the office in this hot summer/cold winter city is the smallest among all seven cities—even lower than in Guangzhou (hot summer/warm winter)—because its $\mathrm{HHI} 18 \mathrm{C}$ is just $15 \%$ higher and its roof thermal transmittance is $22 \%$ lower than in Guangzhou (Table 31 ).

\subsubsection{Influence of HVAC design on energy savings}

Buildings in the three coldest cities (Harbin, Changchun, Beijing) are heated with coal, rather than electricity. The ratio of source energy savings to heating load savings is $f / C_{h}$, where $f$ is the site-to-source energy ratio and $C_{\mathrm{h}}$ is the heating efficiency. $f / C_{\mathrm{h}}$ is higher for coal heating (1.5) than for an electric heat pump (0.9), magnifying the heating source energy penalties associated with cool roofs in coal-heated cities. 


\section{Do not use graphics embedded in this document}

\subsubsection{Influence of tariffs on energy cost savings}

In the four warm-summer cities, commercial electricity prices exceed residential electricity prices by $38 \%$ (Shanghai) to $70 \%$ (Wuhan), helping making cool roof energy cost savings greater for offices than for residences. Meanwhile, the absence of a fuel charge for coal heating in Changchun and Beijing makes the cool-roof energy cost savings positive for offices and zero for residences, even though the cool roof increases residential source energy use in these cities (Figure 15). This particular mixed signal was recently phased out of Harbin with the introduction in late 2012 of a fuel charge for coal heating (Table 5).

\subsubsection{Effect of HVAC design on $N O_{x}$ savings}

Office buildings in Harbin, Changchun and Beijing experience positive $\mathrm{NO}_{x}$ savings even though the cool roof increases source energy use. These $\mathrm{NO}_{\mathrm{x}}$ emission reductions can be traced to the high $\mathrm{NO}_{x}$ emission factors for generation of non-base electricity, which in these three cities range from 4.3 to $5.5 \mathrm{~g} / \mathrm{kWh}$ electricity (Table 9 ). If $3 \mathrm{kWh}$ of coal is required to produce $1 \mathrm{kWh}$ of electricity, the generation emission factors are about $1.4-1.8 \mathrm{~g} \mathrm{NO}_{x}$ per $\mathrm{kWh}$ coal. By contrast, the $\mathrm{NO}_{\mathrm{x}}$ emission factor for a spreader stoker coal furnace is $0.65 \mathrm{~g} / \mathrm{kWh}$ coal (Table 11), or about $60 \%$ lower. This is not too surprising, since $\mathrm{NO}_{x}$ emission factors for coal boilers can vary by a factor greater than 4, depending on design and fuel (US EPA 1995). 


\section{Do not use graphics embedded in this document}

\subsubsection{Sensitivity of cool-roof savings to building parameters}

The current study focuses on the effects on heating and cooling loads of changing roof albedo in code-compliant modern buildings in selected Chinese cities. Load and energy savings were found to scale linearly with increase in roof albedo. While exploring the sensitivity of cool-roof savings to other parameters, such as roof thermal transmittance, building vintage, or building operation, lies outside the scope of the current study, such variations have been investigated in previous work (Akbari et al. 1998, 1999; Akbari and Konopacki 2005; Levinson and Akbari 2010). For example, simulations of nonresidential and high-rise residential U.S. buildings by Akbari et al. (1998) found that cool-roof savings scaled nearly linearly with roof thermal transmittance.

\subsubsection{Recommendations for future cool-roof simulations in China}

The simulations presented here are intended to serve as the first, but not the last, methodical analyses of the potential benefits of cool roofs in China. For example, we expect that further simulations will be needed to evaluate cool roof benefits in other Chinese cities, and to design cool-roof credits, such as trade-offs between roof albedo and roof insulation in Chinese building standards. Future simulations could incorporate the following improvements.

- Including cities in Chinese radiation category 1, such as Lhasa; in western China, such as Lanzhou; and in temperate climates, such as Kunming.

- Basing residential internal heat loads on survey data, rather than DesignBuilder defaults. 


\section{Do not use graphics embedded in this document}

- Accounting for seasonal and equipment-related variations in HVAC operation.

- Refining infiltration rates in both commercial and residential buildings.

- Calculating energy cost savings using time-of-use (TOU) hourly electricity prices, rather than annual average electricity prices, where TOU prices apply.

\subsection{Measurements in Chongqing office building}

\subsubsection{Air conditioning on}

Tuesday, August 14 was mostly sunny, with peak solar irradiance of about $770 \mathrm{~W} / \mathrm{m}^{2}$ and a daily high outside air temperature of $38^{\circ} \mathrm{C}$. The black roof top temperature peaked at $69{ }^{\circ} \mathrm{C}$; while the temperature of the white roof top peaked at $49^{\circ} \mathrm{C}$, which was up to $20^{\circ} \mathrm{C}$ cooler. The bottom of the white roof was up to $8{ }^{\circ} \mathrm{C}$ cooler than that of the black roof. The air temperature in room 510 (white roof) was measured $28^{\circ} \mathrm{C}$, which was slightly higher than that of room 512 (black roof). Because both rooms were air conditioned, we attribute this difference in room air temperature to thermostat performance, rather than to roof solar heat gain. Normalized by room roof area, the air conditioner in room 510 consumed about $50 \mathrm{Wh} \mathrm{m}^{-2}$ day $^{-1}$ less electricity than that in room 512 , for a daily savings of about $9 \%$ (Figure 27 ; Figure 29 ).

\subsubsection{Air conditioning off}

Friday, August 17 was mostly sunny, with peak solar irradiance of about $820 \mathrm{~W} / \mathrm{m}^{2}$ and a daily high outside air temperature of $38^{\circ} \mathrm{C}$. The black roof top temperature reached $71^{\circ} \mathrm{C}$; while the temperature of the white roof top peaked at $50^{\circ} \mathrm{C}$, which was up to 22 ${ }^{\circ} \mathrm{C}$ cooler. The bottom of the white roof was up to $8{ }^{\circ} \mathrm{C}$ cooler than that of the black roof. 


\section{Do not use graphics embedded in this document}

The air in room 510 (white roof) was measured between $34-37^{\circ} \mathrm{C}$, about $1{ }^{\circ} \mathrm{C}$ cooler than in room 512 (black roof) (Figure 31).

\subsubsection{Discussion}

Following ASTM Standard E1980-11 (ASTM 2011), an aged black surface with albedo 0.1 on a well-insulated roof that receives a solar irradiance of $800 \mathrm{~W} / \mathrm{m}^{2}$ would be about $20{ }^{\circ} \mathrm{C}$ warmer than a soiled white roof with albedo 0.6 , and about $29^{\circ} \mathrm{C}$ warmer than a clean white roof with albedo 0.8 . The measured difference in roof surface temperatures (i.e., $22{ }^{\circ} \mathrm{C}$ under irradiance $820 \mathrm{~W} / \mathrm{m}^{2}$ ) indicates that the albedo of white coating over room 510 was about 0.65 .

The $50 \mathrm{Wh} \mathrm{m}^{-2}$ day $^{-1}(9 \%)$ cooling energy saving measured on August 14 is in reasonable agreement with cool roof savings expected for an aged white roof. For example, cooling energy savings measured in summer for new white roofs ranged from 4 to $67 \mathrm{Wh} \mathrm{m}^{-2}$ day $^{-1}(2-39 \%)$ in six commercial buildings in California (Levinson et al. 2005), and from $110-150 \mathrm{Wh} \mathrm{m}^{-2}$ day $^{-1}(13-48 \%)$ in seven commercial buildings in central Florida (Parker et al. 1997). However, while the top and bottom of the white roof were indeed cooler than those of the black roof, we can not be certain that the difference in cooling energy use between the two rooms was due entirely to the white roof; equipment load, occupancy, or doorway infiltration can also affect cooling energy use. Similar reservations apply to the $1^{\circ} \mathrm{C}$ room air temperature reduction observed on August 17 with the air conditioners off. A year-long experiment with continuous monitoring would quantify cool roof savings with greater confidence, capturing both the heating and cooling seasons. 


\section{Do not use graphics embedded in this document}

\subsection{Measurements in Foshan factory}

Saturday, 27 August 2011 was sunny, with peak solar irradiance of $1000 \mathrm{~W} / \mathrm{m}^{2}$ and a daily high outside air temperature of $39^{\circ} \mathrm{C}$. The blue roof top temperature reached 66 ${ }^{\circ} \mathrm{C}$; the temperature of the white roof top peaked at $49{ }^{\circ} \mathrm{C}$, and was up to $17^{\circ} \mathrm{C}$ cooler. The bottom of the white roof was up to $7.5^{\circ} \mathrm{C}$ cooler than that of the blue roof. At a height of $1.7 \mathrm{~m}$, the air in the room with the white roof was $1-3^{\circ} \mathrm{C}$ cooler than the air in the room with the blue roof. The white coating reduced roof heat flux by up to $3.4 \mathrm{~W} / \mathrm{m}^{2}$ during the day, and increased it by up to $0.5 \mathrm{~W} / \mathrm{m}^{2}$ at night (Figure 33).

Over the 5-day trial, the white coating reduced the average daily heat influx, outflux, and net flux (influx - outflux) through the roof by $49 \%, 27 \%$, and $66 \%$ (Table 33 ).

\subsubsection{Discussion}

Again following ASTM Standard E1980-11 (ASTM 2011), a blue surface with albedo 0.3 on a well-insulated roof that receives a solar irradiance of $1000 \mathrm{~W} / \mathrm{m}^{2}$ would be about 26 ${ }^{\circ} \mathrm{C}$ warmer than a clean white roof with albedo 0.8 . The $17^{\circ} \mathrm{C}$ difference observed between the blue and white roofs suggests that soiling reduced the albedo of the white roof to about 0.65 .

The temperature, temperature differences, and heat flux profiles shown in Figure 33 well represent all five days of the trial, and demonstrate that the $1-3^{\circ} \mathrm{C}$ reduction in room air temperature is repeatable.

The white coating substantially reduces the net heat flux through the roof. 


\section{Do not use graphics embedded in this document}

\subsection{Policy recommendations}

Building energy simulation results indicate that cool roofs provide annual energy, cost, $\mathrm{CO}_{2}, \mathrm{NO}_{\mathrm{X}}$, and $\mathrm{SO}_{2}$ savings for both office and residential buildings in all Chinese climates with hot summers. This, combined with the results of the proof-of-concept experiments in Chongqing and Foshan, suggests that cool roofs should be credited or prescribed in such climates.

As of January 2014, local standards in some other southern provinces are proposing similar credits for use of light-color surfaces for roofs and walls, or roof and wall vegetation, in public and/or residential buildings (Lin 2014). This presents opportunities to shape cool surface provisions in Chinese building energy efficiency standards, and to promulgate them to other warm regions in China. Ideas to consider include (a) basing requirements on the aged (soiled), rather than initial (clean), radiative properties of roofs

and walls, because soiling can rapidly reduce the albedos of light-colored surfaces; (b) establishing and referencing a well-defined product rating system to provide these aged radiative properties; and (c) rationalizing the form of cool surface provisions in national and local standards, with variations based strictly on climate- and building-based performance of cool surfaces. These would improve the efficiency, utility, and benefits of cool surface provisions.

Meanwhile, Chinese cool wall provisions should also be considered by regulators in other countries, such as the U.S., that have well-established cool roof requirements, but do not at this time credit or prescribe the use of cool, reflective walls. 


\section{Do not use graphics embedded in this document}

\section{Conclusions and policy implications}

A review of Chinese building standards and academic literature indicates that while the concept of reflective roofing is not new to China, most Chinese cool roof research has taken place within the past decade, and only the latest Chinese energy efficiency standards credit the use of cool roofs. Current national energy efficiency standards and some local energy efficiency standards, such as those in Shanghai, Chongqing, and Jiangsu, credit or recommend cool roofs and/or walls for residential buildings. The current national energy efficiency standard and some local standards in hot-summer provinces, such as Hainan, neither credit nor recommend cool roofs and walls for public buildings. While there are substantial variations in the details of cool surface provisions in Chinese standards, credits (if any) typically take the form of increasing the thermal resistance or reducing the thermal transmittance of the building envelope. Such credits are analogous to those offered in a decade ago in the U.S. building energy efficiency standard ASHRAE 90.1-2004.

EnergyPlus simulations of standard-compliant Chinese office and residential building prototypes in 7 Chinese cities (Harbin, Changchun, Beijing, Chongqing, Shanghai, Wuhan, and Guangzhou) indicate that substituting an aged white roof (albedo 0.6) for an aged gray roof yields positive annual load savings, source energy savings, energy cost savings, $\mathrm{CO}_{2}$ savings, $\mathrm{NO}_{x}$ savings, and $\mathrm{SO}_{2}$ savings in all hot-summer cities (Chongqing, Shanghai, Wuhan, Guangzhou). In these four cities, a cool roof on an office building yields annual savings per unit conditioned roof area of $4.1-10.2 \mathrm{kWh} / \mathrm{m}^{2}$ source energy, $1.0-3.0 \mathrm{RMB} / \mathrm{m}^{2}$ energy cost, $1.0-3.5 \mathrm{~kg} / \mathrm{m}^{2} \mathrm{CO}_{2}, 5.1-13.2 \mathrm{~g} / \mathrm{m}^{2}$ 


\section{Do not use graphics embedded in this document}

$\mathrm{NO}_{x}$, and $9.4-32.6 \mathrm{~g} / \mathrm{m}^{2} \mathrm{SO}_{2}$. Residential source energy and emission savings are comparable to those in offices, but lower electricity prices make residential energy cost savings about $50 \%$ smaller.

Results for the office and residence in Beijing are mixed, with positive annual load, energy cost, $\mathrm{NO}_{x}$, and $\mathrm{SO}_{2}$ savings, but slightly negative annual source energy and $\mathrm{CO}_{2}$ savings. In Harbin and Changchun, heating penalties generally outweighed cooling savings.

A short-term cool roof monitoring experiment in an office building in Chongqing in August 2012 demonstrated that a soiled white roof (albedo around 0.6 ) was about $20^{\circ} \mathrm{C}$ cooler than a neighboring aged black roof (albedo 0.1 ). The room with the white roof used about $9 \%$ less daily air conditioning energy than the room with the black roof, and the air in the room with the white roof was about $1^{\circ} \mathrm{C}$ cooler than that in the room on a day when neither room was air conditioned.

Another short-term cool roof monitoring experiment in a naturally ventilated factory in Foshan (Guangdong Province) in August 2011 showed that a roof with a soiled white coating (albedo around 0.65 ) was about $17^{\circ} \mathrm{C}$ cooler than a neighboring blue roof (albedo 0.3). The white coating lowered room air temperature by about $1-3^{\circ} \mathrm{C}$, and reduced daily roof heat flux by $66 \%$.

The building energy simulations and proof-of-concept experiments indicate that cool roofs are beneficial in hot-summer Chinese climates. Cool roof (and wall) provisions in Chinese building energy should be rationalized, with variations based strictly on climateand building-based performance of cool surfaces. This would improve the efficiency, 


\section{Do not use graphics embedded in this document}

utility, and benefits of these measures. Chinese cool wall provisions should also be considered by regulators in other countries, such as the U.S., that have well-established cool roof requirements, but do not at this time credit or prescribe the use of cool, reflective walls.

While the short-term experimental studies presented here demonstrate the concept of cool roofs in China, experiments with continuous monitoring lasting at least one year are recommended to characterize the effects of increasing roof albedo on annual heating and cooling energy uses. Other topics to explore include the ability of cool roofs to increase occupant comfort in unconditioned spaces, and the extent to which soiling degrades roof and wall albedos in Chinese cities. Long-term cool roof experiments in Chongqing and Guangzhou, as well as a program to evaluate roofing product soiling in several Chinese cities, are all scheduled to begin in 2014.

\section{Acknowledgements}

The authors would like to express their thanks for financial support from the Integrated Research of Key Technologies of Building Envelope System of Cooperation in China and US (2010DFA72740-03-06), and from the US-China Clean Energy Research Center - Building Energy Efficiency. The study was further supported by the Assistant Secretary for Energy Efficiency and Renewable Energy, Office of Building Technology, State, and Community Programs, of the U.S. Department of Energy under Contract No. DE-AC02-05CH11231. We would also like to thank Changqing LIN (MOHURD Research Institute of Standards and Norms); Hunter XU and Justin CHEN (Dow 


\section{Do not use graphics embedded in this document}

Chemical); Zhiqiang WANG (Chongqing University); and Tianzhen HONG (Lawrence

Berkeley National Laboratory).

\section{References}

Akbari H, Konopacki S. 2005. Calculating energy-saving potentials of heat-island reduction strategies. Energy Policy 33, 721-756.

Akbari, H, Konopacki, SJ, Parker, DS, Wilcox, BA, Eley, CN, VanGeem, MG. 1998. Calculations in support of SSP 90.1 for reflective roofs. ASHRAE Transactions 104(1A), 984-995.

Akbari H, Konopacki S, Pomerantz M. 1999. Cooling energy savings potential of reflective roofs for residential and commercial buildings in the United States. Energy 24, 391-407.

Akbari H, Levinson R. 2008. Evolution of cool roof standards in the United States. Advances in Building Energy Research 2, 1-32.

Akbari H, Levinson RM, Rainer L. 2005. Monitoring the energy-use effects of cool roofs on California commercial buildings. Energy and Buildings 37, 1007-1016.

Akbari H, Matthews HD, Seto D. 2012. The long-term effect of increasing the albedo of urban areas. Environmental Research Letters 7(2), 024004.

ASHRAE. 2004. ASHRAE Standard 90.1-2004: Energy Standard for Buildings Except Low-Rise Residential Buildings. American Society of Heating, Refrigerating and AirConditioning Engineers, Atlanta, GA.

ASHRAE. 2010. ASHRAE Standard 90.1-2010: Energy Standard for Buildings Except Low-Rise Residential Buildings. American Society of Heating, Refrigerating and AirConditioning Engineers, Atlanta, GA.

BMCDR. 2010. Beijing heating price. Beijing Municipal Commission of Development and Reform. http://sqjt.beijing.cn/shbst/sdqn/n214033440.shtml [Last Accessed Dec.27th, 2012].

Berdahl P, Akbari H, Levinson R, Miller WA. 2008. Weathering of roofing materials-An overview. Construction and Building Materials 22(4), 423-433.

Bhatia A, Mathur J, Garg V. 2011. Calibrated simulation for estimating energy savings by the use of cool roof in five Indian climatic zones. Journal of Renewable and Sustainable Energy 3, 023108. 


\section{Do not use graphics embedded in this document}

Boixo S, Diaz-Vicente M, Colmenar A, Castro MA. 2012. Potential energy savings from cool roofs in Spain and Andalusia. Energy 38, 425-438.

BP. 2012. BP Statistical Review of World Energy June 2012. http://bp.com/statisticalreview

Cao L, Wang C. 2010. Calculation of $\mathrm{SO}_{2}$ and $\mathrm{NO}_{x}$ emission factors of China's national power grids. China Environmental Science 30 (1), 7-11.

CCC. 2006. Design Standard for Energy Efficiency of Public Buildings in Chongqing. 2006. DBJ50-052-2006. Chongqing Commission of Construction.

CCUSC. 2010a. Design Standard for Energy Efficiency (65\%) of Residential Buildings in Chongqing. 2010. DBJ50-071-2010. Chongqing Commission of Urban and Suburban Construction.

CCUSC. 2010b. Design Standard for Energy Efficiency (50\%) of Residential Buildings in Chongqing. DBJ50-102-2010, Chongqing Commission of Urban and Suburban Construction.

CERC-BEE. 2014. US-China Clean Energy Research Center - Building Energy Efficiency. http://cercbee.lbl.gov

CDRC. 2011. Announcement on regulating the heating price in Changchun urban areas. Changchun Development and Reform Commission.

http://www.ccdrc.gov.cn/ccNEWS.asp?id=7686 .

CABRADI. 1965. Building temperature reduction in extreme hot weather, 1st ed. China Academy of Building Research Architectural Design Institute. China Industry Press.

CG. 2011. The Twelfth Five-year Plan for National Economic and Social Development of the People's Republic of China. Chinese Government.

http://www.gov.cn/2011/h/content 1825838 2.htm

GAQSIQPRC. 2009. Monitoring and testing for energy saving of coal fired industrial boilers. General Administration of Quality Supervision, Inspection and Quarantine of the People's Republic of China.

HACP. 2012. Announcement on temporary trial on heating usage pricing. Harbin Administration of Commodity Price.

http://www.hrbpb.gov.cn/export/shouye/tztg/gztz/article_0142.html [Last Accessed Dec.27th, 2012].

HCC. 2005. Design Standard for Energy Efficiency of Residential Buildings-Hainan Province JDJ01-2005, Hainan Commission of Construction.

HCC. 2006. Design Standard for Energy Efficiency of Public Buildings in Hainan Province, JBJ03-2006. Hainan Commission of Construction. 


\section{Do not use graphics embedded in this document}

Hildebrandt EW, Bos W, Moore R. 1998. Assessing the impacts of white roofs on building energy loads. ASHRAE Transactions 104(1), 810-820.

Hongye Technology. 2012. Hongye Load Calculation Version 7.0. HVAC Load and Building Envelope Management System, Hongye Technology, July 17, 2012.

JCHC. 2010. Design Standard for Energy Efficiency of Public Buildings in Jiangsu Province, DGJ32 J 96-2010. Jiangsu Commission of Housing and Construction.

Jiang F. 2012. Experimental study on insulating effect of solar reflecting roofs and energy saving. Wall Material Innovation \& Energy Saving in Building 3, 46-48.

Jo JH, Carlson JD, Golden JS, Bryan H. 2010. An integrated empirical and modeling methodology for analyzing solar reflective roof technologies on commercial buildings. Building and Environment 45, 453-460.

Kolokotroni M, Gowreesunker, BL, Giridharan R. 2011. Cool roof technology in London: An experimental and modelling study. Energy and Buildings, in press, http://dx.doi.org/10.1016/j.enbuild.2011.07.011

Konopacki S, Akbari H, Pomerantz M, Gabersek S, Gartland L. 1997. Cooling energy savings potential of light-colored roofs for residential and commercial buildings in 11 US metropolitan areas. LBNL-39433, Lawrence Berkeley National Laboratory, Berkeley CA. http://dx.doi.org/10.2172/508151

Konopacki S, Akbari H. 2001. Measured energy savings and demand reduction from a reflective roof membrane on a large retail store in Austin. LBNL-47149, Lawrence Berkeley National Laboratory, Berkeley, CA. http://repositories.cdlib.org/lbnl/LBNL47149

Konopacki S, Gartland L, Akbari H, Rainer L. 1998. Demonstration of energy savings of cool roofs. LBNL-40673, Lawrence Berkeley National Laboratory, Berkeley, CA. http://dx.doi.org/10.2172/296885

Levinson R, Akbari H, Konopacki S, Bretz S. 2005. Inclusion of cool roofs in nonresidential Title 24 prescriptive requirements. Energy Policy 33, 151-170.

Levinson R, Akbari H. 2010. Potential benefits of cool roofs on commercial buildings: conserving energy, saving money, and reducing emission of greenhouse gases and air pollutants. Energy Efficiency 3 (1), 53-109.

Levinson R. 2009. Mean solar irradiance ratio: winter to summer. http://coolcolors.lbl.gov/assets/docs/Papers/Supplements/mean\%20solar\%20irradiance \%20ratio\%20winter\%20to\%20summer.pdf

Lin C. 2014. Personal communication with LIN Changqing, Research Institute of Standards and Norms (RISN), Ministry of Housing, Urban, and Rural Development (MOHURD), China. 


\section{Do not use graphics embedded in this document}

MOHURD. 1993. Design Standard for Residential Building Thermal Performance. Ministry of Housing and Urban-Rural Development, People's Republic of China.

MOHURD. 2002. The Compulsory Provisions of Engineering Construction Standards, China Architecture Industry Press.

MOHURD. 2003. Design Standard for Energy Efficiency of Residential Buildings in Hot Summer and Warm Winter Zones. Ministry of Housing and Urban-Rural Development, People's Republic of China.

MOHURD. 2005. Design Standard for Energy Efficiency of Public Buildings. Ministry of Housing and Urban-Rural Development, People's Republic of China.

MOHURD. 2006. Evaluation Standard for Green Building, GB/T 50378-2006. Ministry of Housing and Urban-Rural Development, People's Republic of China.

MOHURD. 2009. Heating, Ventilation and Air Conditioning. 1st ed. China Institute of Building Standard Design \& Research. Beijing: China Planning Press.

MOHURD. 2010a. Design Standard for Energy Efficiency of Residential Buildings in Hot Summer and Cold Winter Zones - JGJ134-2010. Ministry of Housing and Urban-Rural Development, People's Republic of China.

MOHURD. 2010b. Design Standards for Energy Efficiency of Residential Buildings in Cold and Severe Cold Zones, JGJ26-2010. Ministry of Housing and Urban-Rural Development, People's Republic of China.

MOHURD. 2012. Design Standard for Energy Efficiency of Residential Buildings in Hot Summer and Warm Winter Zones, JGJ75-2012. Ministry of Housing and Urban-Rural Development, People's Republic of China.

Navigant. 2009. Assessment of international urban heat island research: review and critical analysis of international UHI studies. Prepared for U.S. Department of Energy by Navigant Consulting, Vienna, VA. Nov 14.

http://www.eereblogs.energy.gov/buildingenvelope/file.axd?file=2011\%2f10\%2fuhi_repo rt.pdf

NDRC. 2011a. Announcement on changing the electricity price on the "Southern Grid". National Development and Reform Commission. [2011]2618.

NDRC. 2011b. Announcement on changing the electricity price on the "Northern Grid". National Development and Reform Commission. [2011]2619.

NDRC. 2011c. Announcement on changing the electricity price on the "East Northern Grid". National Development and Reform Commission. [2011]2620.

NDRC. 2011d. Announcement on changing the electricity price on the "West Northern Grid". National Development and Reform Commission. [2011]2621. 


\section{Do not use graphics embedded in this document}

NDRC. 2011e. Announcement on changing the electricity price on the "Eastern Grid". National Development and Reform Commission. [2011]2622.

NDRC. 2011f. Announcement on changing the electricity price on the "Central Grid". National Development and Reform Commission. [2011]2623.

NDRC. 2012. 2012 Baseline Emission Factors for Regional Power Grids in China. National Development and Reform Commission, People's Republic of China. http://cdm.ccchina.gov.cn/WebSite/CDM/UpFile/File2975.pdf .

Parker D, Huang Y, Konopacki S, Gartland L, Sherwin J, Gu L. 1998. Measured and simulated performance of reflective roofing systems in residential buildings. ASHRAE Transactions, 104(1). http://www.fsec.ucf.edu/en/publications/html/FSEC-PF-331-98

Parker D, Sonne J, Sherwin J. 1997. Demonstration of cooling savings of light-colored roof surfacing in Florida commercial buildings: retail strip mall. FSEC-CR-964-97, Florida Solar Energy Center Report. Cocoa, FL.

http://www.fsec.ucf.edu/en/publications/pdf/FSEC-CR-964-97.pdf

Parker DS, Barkaszi SF. 1997. Roof solar reflectance and cooling energy use: field research results from Florida. Energy and Buildings 25, 105-115.

Parker DS, Sherwin JR, Sonne JK. 1998. Measured performance of a reflective roofing system in a Florida commercial building. ASHRAE Transactions 104(1B), 789-793.

Romeo C, Zinzi M. 2011. Impact of a cool roof application on the energy and comfort performance in an existing non-residential building. A Sicilian case study. Energy and Buildings, in press, http://dx.doi.org/10.1016/j.enbuild.2011.07.023

Rosado PJ, Faulkner D, Sullivan DP, Levinson R. 2013. Measured temperature reductions and energy savings from a cool tile roof on a central California home. Submitted to Energy \& Buildings.

Rosenfeld AH, Akbari H, Romm JJ, Pomerantz M. 1998. Cool communities: strategies for heat island mitigation and smog reduction. Energy and Buildings 28, 51-62.

Santamouris M, Synnefa A, Karlessi T. 2011. Using advanced cool materials in the urban built environment to mitigate heat islands and improve thermal comfort conditions, Solar Energy 85, 3085-3102.

Santamouris, M. 2012. Cooling the cities-A review of reflective and green roof mitigation technologies to fight heat island and improve comfort in urban environments. Solar Energy, in press, http://dx.doi.org/10.1016/j.solener.2012.07.003.

SAPRC. 2010. Room air conditioning energy efficiency standard GB 12021.3-2010. Standardization Administration of the People's Republic of China, General Administration of Quality Supervision, Inspection and Quarantine of the People's Republic of China. http://www.csres.com/detail/209545.html . 


\section{Do not use graphics embedded in this document}

SHCUSCT. 2011. Design Standard for Energy Efficiency of Residential Buildings (Shanghai). 2011. DGJ08-205-2011, Shanghai Commission of Urban and Suburban Construction and Transportation.

SHCUSCT. 2012. Design Standard for Energy Efficiency of Public Buildings (Shanghai), DGJ 08-107-2012. Shanghai Commission of Urban and Suburban Construction and Transportation.

Shen H, Tan H, Liu X, Miki K. 2007. Energy saving effect of solar reflective paint's application on roofs. Shanghai Society of Refrigeration 2007 conference journal set, 352-354.

Shen $\mathrm{H}$, Tan H. 2009. Effect of solar reflective coatings on factory building energy saving in hot summer and warm winter zone. Building Science 125 (13), 49-53.

Sleiman M, Ban-Weiss G, Gilbert HE, Francois D, Berdahl P, Kirchstetter TW, Destaillats H, Levinson R. 2011. Soiling of building envelope surfaces and its effect on solar reflectance-Part I: Analysis of roofing product databases. Solar Energy Materials \& Solar Cells 95, 3385-3399.

Sleiman M, Kirchstetter TW, Berdahl P, Gilbert HE, Quelen S, Marlot L, Preble CV, Chen S, Montalbano A, Rosseler O, Akbari H, Levinson R, Destaillats H. 2014. Soiling of building envelope surfaces and its effect on solar reflectance - Part II: Development of an accelerated aging method for roofing materials. Solar Energy Materials and Solar Cells 122, 271-281.

Sun G. 2010. Coal in China: Resources, uses, and advanced coal technologies. Coal Initiative-Pew Center on Global Climate Change, March 2010. Online at http://www.c2es.org/docUploads/coal-in-china-resources-uses-technologies.pdf .

Synnefa A, Saliari M, Santamouris M. 2012. Experimental and numerical assessment of the impact of increased roof reflectance on a school building in Athens. Energy and Buildings, in press, http://dx.doi.org/10.1016/j.enbuild.2012.01.044 .

Synnefa A, Santamouris M, Akbari H. 2007. Estimating the effect of using cool coatings on energy loads and thermal comfort in residential buildings in various climatic conditions. Energy and Buildings 39, 1167-1174.

TUBEEC. 2010. 2010 Annual Report on China Building Energy Efficiency. 1st ed. Tsinghua University Building Energy Efficiency Center. Beijing, China: China Architecture \& Building Press.

TUBEEC. 2011. 2011 Annual Report on China Building Energy Efficiency. 1st ed. Beijing, China: Tsinghua University Building Energy Efficiency Center. China Architecture \& Building Press. http://www.docin.com/p-67588012.html .

US EIA. 2011. Electric Power Annual (EPA) 2011, Table A-3. U.S. Energy Information Administration. http://www.eia.gov/electricity/annual/html/epa_a_03.html . 


\section{Do not use graphics embedded in this document}

US EIA. 2012. China Analysis Brief. US Energy Information Administration. http://www.eia.gov/countries/country-data.cfm?fips=CH\&trk=p1 [accessed 31 Aug 2012].

US EPA. 1995. Compilation of air pollutant emission factors, Volume I: Stationary point and area sources, AP-42, $5^{\text {th }}$ ed, January. U.S. Environmental Protection Agency. http://www.epa.gov/ttnchie1/ap42 .

US EPA. 2004. Unit conversions, emission factors, and other reference data, November 2004. U.S. Environmental Protection Agency. http://www.epa.gov/cpd/pdf/brochure.pdf .

Wang W. 2007. Improving heat insulation of grain storehouse. Journal of the Chinese Cereals and Oils Association 22 (4), 102-105.

Xu T, Sathaye J, Akbari H, Garg V, Tetali S. 2012. Quantifying the direct benefits of cool roofs in an urban setting: Reduced cooling energy use and lowered greenhouse gas emissions. Building and Environment 48, 1-6.

Yang S, Jiang F, Mai E, Zhou Q. 2012. Experimental study on insulating effect of solar reflecting lightweight roof. New Building Materials 7, pp.37-39, 62.

YCUSC. 2011. Design standard for energy efficiency of civil buildings, DBJ 53/T-392011. Yunnan Commission of Urban and Suburban Construction. 


\section{Tables}

Table 1. Characteristics of the simulated office and residential building prototypes.

\begin{tabular}{|c|c|c|}
\hline & Office & Residence \\
\hline Layout & $\begin{array}{l}\text { top floor } \\
\text { (office, corridor, } \\
\text { stairway or elevator) }\end{array}$ & $\begin{array}{l}\text { top floor } \\
\text { (bedroom, lounge, bathroom, } \\
\text { kitchen, corridor, stairway or } \\
\text { elevator) }\end{array}$ \\
\hline $\begin{array}{l}\text { Conditioned floor area, } \\
\text { conditioned roof area }\left(\mathrm{m}^{2}\right)\end{array}$ & 732 & 387 \\
\hline Story height $(\mathrm{m})$ & 3.5 & 3 \\
\hline Window area $\left(\mathrm{m}^{2}\right)$ & $\begin{array}{l}3.0[1.2 \times 1.5] \\
3.24[1.8 \times 1.8]\end{array}$ & $\begin{array}{l}2.5[1.8 \times 2.0] \\
2.5[1.8 \times 2.4]\end{array}$ \\
\hline Door area $\left(\mathrm{m}^{2}\right)$ & $1.9[0.9 \times 2.1]$ & $1.9[0.9 \times 2.1]$ \\
\hline $\begin{array}{l}\text { Ratio of window area to } \\
\text { wall area }\end{array}$ & $\begin{array}{l}0.29 \text { (west) } \\
0.29 \text { (east) }\end{array}$ & $\begin{array}{l}0.23 \text { (north) } \\
0.3 \text { (south) }\end{array}$ \\
\hline $\begin{array}{l}\text { Building shape coefficient } \\
\text { (surface to volume ratio) } \\
\left(\mathrm{m}^{-1}\right)^{a}\end{array}$ & 0.22 & 0.27 \\
\hline $\begin{array}{l}\text { Roof, wall, window thermal } \\
\text { transmittance }\left(\mathrm{W} \mathrm{m}^{-2} \mathrm{~K}^{-1}\right)\end{array}$ & See Table 31 & See Table 31 \\
\hline Roof construction & See Table C-1 & See Table C-1 \\
\hline Wall construction & See Table C-3 & See Table C-3 \\
\hline $\begin{array}{l}\text { Occupant density } \\
\left(\text { person } / \mathrm{m}^{2}\right)\end{array}$ & $\begin{array}{l}0.25^{\mathrm{b}} \text { (office) } \\
0.02^{\mathrm{b}} \text { (corridors) }\end{array}$ & $\begin{array}{l}0.1 \text { (bedroom) }^{\mathrm{e}} \\
0.15 \text { (lounge) }^{\mathrm{e}} \\
0.1 \text { (kitchen) }^{\mathrm{e}} \\
0.1 \text { (toilet) }^{\mathrm{e}} \\
0.1 \text { (corridors) }^{\mathrm{e}}\end{array}$ \\
\hline Equipment load $\left(\mathrm{W} / \mathrm{m}^{2}\right)$ & $\begin{array}{l}20^{\mathrm{b}} \text { (office) } \\
0^{\mathrm{b}} \text { (corridors) }\end{array}$ & $\begin{array}{l}3.5 \text { (bedroom) }^{f} \\
4 \text { (living room) }^{f} \\
30 \text { (kitchen) }^{f} \\
1.5 \text { (toilet) }^{f} \\
2 \text { corridors) }^{f}\end{array}$ \\
\hline Lighting load $\left(\mathrm{W} / \mathrm{m}^{2}\right)$ & $\begin{array}{l}11^{\mathrm{b}} \text { (office) } \\
5^{\mathrm{c}} \text { (corridors) }\end{array}$ & $\begin{array}{l}5 \text { (bedroom) }^{f} \\
5 \text { (living room) }^{f} \\
5 \text { (kitchen) }^{f} \\
5 \text { (toilet) }^{f} \\
5 \text { (corridors) }^{f}\end{array}$ \\
\hline Cooling setpoint $\left({ }^{\circ} \mathrm{C}\right)$ & $\begin{array}{l}26 \text {, with setback to } \\
37^{\mathrm{b}}\end{array}$ & $\begin{array}{l}\text { 26, with setback to } 37 \text { (Beijing } \\
\text { Chongqing, Wuhan, Shanghai }\end{array}$ \\
\hline
\end{tabular}




\section{Do not use graphics embedded in this document}

\begin{tabular}{|c|c|c|}
\hline & & $\begin{array}{l}\text { Guangzhou) }{ }^{\mathrm{d}} \\
\text { No cooling in Harbin and } \\
\text { Changchun } \\
\end{array}$ \\
\hline Cooling schedule & $\begin{array}{l}\text { Weekdays 07:00 - } \\
\text { 18:00 (excluding } \\
\text { holidays) } \\
\end{array}$ & $\begin{array}{l}\text { Weekdays } 18: 00-09: 00^{9} \\
\text { Holidays and weekends } 0: 00- \\
\text { 24:00 }\end{array}$ \\
\hline Heating setpoint $\left({ }^{\circ} \mathrm{C}\right)$ & $\begin{array}{l}20, \text { with setback to } \\
12^{b}\end{array}$ & $\begin{array}{l}\text { 18, with setback to } 12 \text { (Harbin, } \\
\text { Changchun, Beijing, Chongqing } \\
\text { Shanghai } \\
\text { ', Wuhan ') } \\
\text { 16, with setback to } 12 \text { (Guangzhou } \\
\text { i) }\end{array}$ \\
\hline Heating schedule & $\begin{array}{l}\text { Weekdays 07:00 - } \\
\text { 18:00, excluding } \\
\text { holidays }{ }^{\text {b }}\end{array}$ & $\begin{array}{l}\text { Weekdays } 18: 00-09: 00 \\
\text { Holidays and weekends } 0: 00- \\
24: 00^{h}\end{array}$ \\
\hline $\begin{array}{l}\text { Minimum fresh air via } \\
\text { mechanical + natural } \\
\text { ventilation } \\
\text { (L/s-person) }\end{array}$ & $8.33^{c}$ & None \\
\hline Infiltration (ac/h) & $0.75^{j}$ & $\begin{array}{l}0.5^{\mathrm{k}} \text { (Harbin, Changchun) } \\
1.0^{\mathrm{k}} \text { (Beijing, Chongqing, } \\
\text { Shanghai, Wuhan, Guangzhou) }\end{array}$ \\
\hline
\end{tabular}

${ }^{a}$ Calculated for a five-floor office building and a nine-floor residential building.

${ }^{\mathrm{b}}$ Suggestion for simulation from MOHURD (2005).

${ }^{\mathrm{c}}$ Prescriptive requirement from MOHURD (2005).

${ }^{d}$ Prescriptive requirement from MOHURD (2003, 2010a, 2010b).

${ }^{\text {e}}$ Assumed. Density averages two scenarios: 3 bedrooms and 2 living rooms for 5 persons of 3 generations, and 2 bedrooms and 3 living rooms for 3 persons of 2 generations.

${ }^{f}$ Equipment load and lighting load are assigned default values by DesignBuilder according to the function of the room.

${ }^{g}$ In Chinese homes, only bedrooms and living rooms are cooled in hot summer/cold winter and hot summer/warm winter climates.

${ }^{\mathrm{h}}$ Chinese homes are assumed to be conditioned only outside business hours.

${ }^{i}$ Assumed. In Chinese homes, only bedroom and lounge are heated in hot summer/cold winter and hot summer/warm winter climates.

jSuggestion from China Institute of Building Standard Design \& Research and MOHURD (2009).

${ }^{\mathrm{k}}$ Residential infiltration rates set to meeting prescriptive natural ventilation requirement $(\mathrm{ac} / \mathrm{h})$ from MOHURD (2003, 2010a, 2010b). However, infiltration rate in Beijing is set to match those in the four hotsummer climates. 


\section{Do not use graphics embedded in this document}

Table 3. Assumptions about prototype HVAC equipment and COPs (or efficiencies) used to compute site energy, source energy, energy cost, and emissions savings from heating and cooling load savings.

\begin{tabular}{|c|c|c|c|c|c|}
\hline Prototype & City & $\begin{array}{l}\text { Heating } \\
\text { equipment }\end{array}$ & $\begin{array}{l}\text { Heating } \\
\text { COP (heat } \\
\text { pump) or } \\
\text { efficiency } \\
\text { (furnace) }\end{array}$ & $\begin{array}{l}\text { Cooling } \\
\text { equipment }\end{array}$ & $\begin{array}{l}\text { Cooling } \\
\text { COP }\end{array}$ \\
\hline Office & \begin{tabular}{|l} 
Harbin, \\
Changchun, \\
Beijing
\end{tabular} & $\begin{array}{l}\text { Coal } \\
\text { furnace }\end{array}$ & $0.7^{\mathrm{a}}$ & Split system & $3.3^{b}$ \\
\hline Office & $\begin{array}{l}\text { Chongqing, } \\
\text { Shanghai, } \\
\text { Wuhan, } \\
\text { Guangzhou }\end{array}$ & Split system & $3.5^{\mathrm{c}}$ & Split system & $3.3^{b}$ \\
\hline Residential & $\begin{array}{l}\text { Harbin, } \\
\text { Changchun }\end{array}$ & $\begin{array}{l}\text { Coal } \\
\text { furnace }\end{array}$ & $0.7^{c}$ & None & - \\
\hline Residential & Beijing & $\begin{array}{l}\text { Coal } \\
\text { furnace }\end{array}$ & $0.7^{\mathrm{c}}$ & Split system & $3.3^{b}$ \\
\hline Residential & $\begin{array}{l}\text { Chongqing, } \\
\text { Shanghai, } \\
\text { Wuhan, } \\
\text { Guangzhou }\end{array}$ & Split system & $3.5^{\mathrm{c}}$ & Split system & $3.3^{b}$ \\
\hline
\end{tabular}

${ }^{a}$ Assumed based on mid range of prescriptions from GAQSIQPRC (2009).

${ }^{\text {b }}$ Suggestion in SAPRC (2010).

${ }^{\mathrm{C}}$ Assumed based on experience with split systems. Note that actual heating COP may be less than ideal heating COP (cooling COP +1 ) because some energy is needed to defrost the equipment, and/or if the temperature difference is greater in heating mode than in cooling mode. 


\section{Do not use graphics embedded in this document}

Table 5. Electricity prices (RMB/kWh) and coal heating prices (RMB/GJ) in each simulated city.

\begin{tabular}{|l|l|l|l|l|}
\hline & \multicolumn{2}{|c|}{ Electricity $^{\text {a }}$} & \multicolumn{2}{c|}{ Coal heating $^{\text {b }}$} \\
\hline City & Commercial & Residential $^{\prime}$ & Commercial & Residential \\
\hline Harbin & 0.9255 & 0.5000 & 52.74 & 44.81 \\
\hline Changchun & 0.9320 & 0.5183 & 0 & 0 \\
\hline Beijing & 0.7858 & 0.4800 & 0 & 0 \\
\hline Chongqing & 0.8193 & 0.5125 & - & - \\
\hline Shanghai & 0.8488 & 0.6145 & - & - \\
\hline Wuhan & 0.9618 & 0.5655 & - & - \\
\hline Guangzhou & 0.9388 & 0.6066 & - & - \\
\hline
\end{tabular}

${ }^{a}$ As of December 2011 (NDRC 2011a-f).

${ }^{b}$ As of December 2012, building occupants in Harbin pay a flat annual rate for coal heating (RMB/heated floor area) plus a fuel surcharge (RMB/GJ) (HACP 2012), while those in Changchun and Beijing pay only a flat annual rate (RMB/heated floor area) (BMCDR 2010; CDRC 2011). Buildings elsewhere are assumed not to use coal heating.

Table 7. Present value multiplier $b$ (ratio of present value of lifetime energy cost savings to annual energy cost savings) computed from Eq. (1) for various combinations of roof lifetime $N$ and real (inflation-adjusted) annual rate of return $r$.

\begin{tabular}{|l|c|r|r|r|}
\hline & \multicolumn{4}{|c|}{ Real annual rate of return $r$} \\
\hline Roof service life $N$ (years) & $1 \%$ & \multicolumn{1}{|c|}{$3 \%$} & \multicolumn{1}{c|}{$5 \%$} & \multicolumn{1}{c|}{$7 \%$} \\
\hline 10 & 9.5 & 8.5 & 7.7 & 7.0 \\
\hline 15 & 13.9 & 11.9 & 10.4 & 9.1 \\
\hline 20 & 18.0 & 14.9 & 12.5 & 10.6 \\
\hline 25 & 22.0 & 17.4 & 14.1 & 11.7 \\
\hline 30 & 25.8 & 19.6 & 15.4 & 12.4 \\
\hline
\end{tabular}




\section{Do not use graphics embedded in this document}

Table 9. Electricity emission factors (mass of pollutant emitted per unit non-base electrical energy supplied to the grid).

\begin{tabular}{|l|l|l|l|}
\hline & \multicolumn{3}{|l|}{ Electricity emission factor } \\
\hline & $\begin{array}{l}\mathrm{CO}_{2} \\
(\mathrm{~kg} / \mathrm{kWh})^{\mathrm{a}}\end{array}$ & $\begin{array}{l}\mathrm{NO}_{\mathrm{x}} \\
(\mathrm{g} / \mathrm{kWh})^{\mathrm{b}}\end{array}$ & $\begin{array}{l}\mathrm{SO}_{2} \\
(\mathrm{~g} / \mathrm{kWh})^{\mathrm{b}}\end{array}$ \\
\hline Harbin & 1.0935 & 5.5 & 6.5 \\
\hline Changchun & 1.0935 & 5.5 & 6.5 \\
\hline Beijing & 1.0021 & 4.3 & 9.4 \\
\hline Chongqing & 0.9944 & 5.4 & 13.1 \\
\hline Shanghai & 0.8244 & 3.9 & 7.2 \\
\hline Wuhan & 0.9944 & 5.4 & 13.1 \\
\hline Guangzhou & 0.9344 & 3.7 & 9.1 \\
\hline
\end{tabular}

${ }^{\mathrm{a}} \mathrm{NRDC}(2012)$.

${ }^{\mathrm{b}}$ Cao and Wang (2010).

Table 11. Coal emission factors (mass of pollutant emitted per unit fuel energy consumed).

\begin{tabular}{|c|c|c|}
\hline $\mathrm{CO}_{2}(\mathrm{~kg} / \mathrm{kWh})^{\mathrm{a}, \mathrm{b}}$ & $\mathrm{NO}_{\mathrm{x}}(\mathrm{g} / \mathrm{kWh})^{\mathrm{a}, \mathrm{c}}$ & $\mathrm{SO}_{2}(\mathrm{~g} / \mathrm{kWh})^{\mathrm{a}, \mathrm{c}, \mathrm{d}}$ \\
\hline 0.3292 & 0.65 & 2.7 \\
\hline
\end{tabular}

${ }^{a}$ For subbituminous coal, which makes up the largest share $(42.6 \%)$ of China's accumulated proven coal resources (Sun 2010) and has an energy content (higher heating value) of $5573 \mathrm{kWh} / \mathrm{t}$ (US EPA 2004).

${ }^{\mathrm{b}}$ From US EIA (2011), which notes that coal $\mathrm{CO}_{2}$ emission factors are independent of combustion system type and boiler firing configuration.

${ }^{c}$ For a spreader stoker burning sub-bituminous coal (section 1.1 of US EPA 1995).

${ }^{d}$ Assumes coal is $1.06 \%$ sulfur by mass (Sun 2010 ). 


\section{Do not use graphics embedded in this document}

Table 13. Characteristics of tested rooms in Chongqing University office building.

\begin{tabular}{|c|c|c|}
\hline & Room 510 & Room 512 \\
\hline \multicolumn{3}{|l|}{ Roof surface } \\
\hline Color & White & Black (uncoated) \\
\hline Initial solar reflectance & $\sim 80 \%$ & $\sim 10 \%$ (visual estimate) \\
\hline Coating date & 2012-05-09 & - \\
\hline Coating make and model & $\begin{array}{l}\text { Shanghai Rongtuo Industry } \\
\text { Company Ltd. MetaSeal No.2 } \\
\text { Cool-Roofing System }\end{array}$ & - \\
\hline Coating material & acrylic acid & - \\
\hline $\begin{array}{l}\text { Roof structure (layers, top } \\
\text { to bottom) }\end{array}$ & $\begin{array}{l}\text { Waterproofing layer / cement } \\
\text { mortar / aerated concrete / } \\
\text { cement mortar }\end{array}$ & Same \\
\hline $\begin{array}{l}\text { Roof assembly thermal } \\
\text { resistance }\left(\mathrm{m}^{2} \mathrm{~K} \mathrm{~W}^{-1}\right)^{\mathrm{a}}\end{array}$ & 0.93 & Same \\
\hline Floor \& roof area $\left(\mathrm{m}^{2}\right)$ & 28.8 & Same \\
\hline Ceiling height (m) & 2.78 & Same \\
\hline Plenum height (m) & 0.65 & \\
\hline $\begin{array}{l}\text { Doors (number, total area } \\
{\left[\mathrm{m}^{2}\right] \text { ) }}\end{array}$ & $1,1.89$ & Same \\
\hline $\begin{array}{l}\text { Windows (number, } \\
\text { orientation, total area }\left[\mathrm{m}^{2}\right] \text { ) }\end{array}$ & 2, northwest, 2.7 & 2, northwest, 2.7 \\
\hline \multicolumn{3}{|l|}{ Cooling equipment } \\
\hline Make and model & \begin{tabular}{|l|} 
Gree KFR- \\
50LW/K(50520L)A-N5 \\
\end{tabular} & Same \\
\hline COP & 2.68 & Same \\
\hline Capacity (W) & 5000 & Same \\
\hline Setpoint $\left({ }^{\circ} \mathrm{C}\right)$ & 26 & Same \\
\hline Schedule & 08:00 - 22:00 & Same \\
\hline
\end{tabular}


Table 15. Measurement sensors and protocol in Chongqing University office building.

\begin{tabular}{|c|c|}
\hline Measurement & Details \\
\hline \multicolumn{2}{|l|}{$\begin{array}{l}\text { Roof top, roof bottom, } \\
\text { ceiling temperature } \\
\text { (rooms } 510 \& 512 \text { ) }\end{array}$} \\
\hline Sensor type & Handheld infrared thermometer \\
\hline Sensor make \& model & Labeled "Orientek" (true make and model uncertain) \\
\hline Sensor accuracy & Unknown \\
\hline Protocol & $\begin{array}{l}\text { Instrument held } 0.6 \mathrm{~m} \text { from roof top, } 0.8 \mathrm{~m} \text { from roof } \\
\text { bottom, } 0.8 \mathrm{~m} \text { from ceiling; measurements performed } \\
\text { manually and recorded hourly from } 08: 00 \text { to } 22: 00\end{array}$ \\
\hline \multicolumn{2}{|l|}{$\begin{array}{l}\text { Room air temperature } \\
\text { (room 510) }\end{array}$} \\
\hline Sensor type & Temperature/humidity micrologger \\
\hline Sensor make \& model & YANTAI Yuanzhi Technology Co. (no model name) \\
\hline Sensor accuracy & $0.5^{\circ} \mathrm{C}$ \\
\hline Protocol & $\begin{array}{l}\text { Sensor suspended } 1.5 \mathrm{~m} \text { above floor; measurement } \\
\text { logged internally every } 10 \mathrm{~min}\end{array}$ \\
\hline \multicolumn{2}{|l|}{$\begin{array}{l}\text { Room air temperature } \\
\text { (room 512) }\end{array}$} \\
\hline Sensor type & Handheld digital hygrometer \\
\hline Sensor make \& model & Dwyer Instruments model $485-2$ \\
\hline Sensor accuracy & $0.5^{\circ} \mathrm{C}$ \\
\hline Protocol & $\begin{array}{l}\text { Sensor held } 1.5 \mathrm{~m} \text { above floor; hourly measurements } \\
\text { recorded manually }\end{array}$ \\
\hline \multicolumn{2}{|l|}{$\begin{array}{l}\text { Global horizontal solar } \\
\text { irradiance }\end{array}$} \\
\hline Sensor type & First-class pyranometer \\
\hline Sensor make \& model & $\begin{array}{l}\text { Jinzhou Sunshine Technology Development model TBQ- } \\
2\end{array}$ \\
\hline Sensor accuracy & $\begin{array}{l}\text { Unclear; see } \\
\text { http://www.1718w.com/taiyangfusheji2/TBQ-2-B.html }\end{array}$ \\
\hline Protocol & Sensor installed horizontally on roof top \\
\hline \multicolumn{2}{|l|}{$\begin{array}{l}\text { Cooling electricity use } \\
\text { (rooms } 510 \& 512 \text { ) }\end{array}$} \\
\hline Sensor type & Power meter \\
\hline Sensor make \& model & $\begin{array}{l}\text { Shanghai LiuYi Electron Science Company LTD Model } \\
\text { DD862-4 }\end{array}$ \\
\hline Sensor accuracy & $0.1 \mathrm{kWh}$ \\
\hline
\end{tabular}


Table 17. Characteristics of tested rooms in Foshan factory.

\begin{tabular}{|c|c|c|}
\hline & Under blue roof & Under white roof \\
\hline \multicolumn{3}{|l|}{ Roof surface } \\
\hline Color & Blue & White \\
\hline Initial solar reflectance & 0.29 & 0.82 \\
\hline Date coated & N/A & 2 July 2011 \\
\hline Make and model of coating & N/A & $\begin{array}{l}\text { Guangyi Coating, } \\
\text { Architectural reflective } \\
\text { thermal insulation } \\
\text { coatings }\end{array}$ \\
\hline Coating material & $\mathrm{N} / \mathrm{A}$ & Unknown \\
\hline Roof structure (layers, top to bottom) & $\begin{array}{l}20 \mathrm{~mm} \text { steel plate }+ \\
100 \mathrm{~mm} \text { XPS }+30 \mathrm{~mm} \\
\text { calcium-resin insulating } \\
\text { board }\end{array}$ & Same \\
\hline $\begin{array}{l}\text { Roof assembly thermal resistance } \\
\left(\mathrm{m}^{2} \mathrm{~K} \mathrm{~W}^{-1}\right)\end{array}$ & 3.39 & Same \\
\hline Roof area $\left(\mathrm{m}^{2}\right)$ & 480 & Same \\
\hline Roof slope $\left({ }^{\circ}\right)$ & 6 & Same \\
\hline Roof height (m) & 12 & Same \\
\hline Doors (number, total area $\left[\mathrm{m}^{2}\right]$ ) & 2,50 & Same \\
\hline $\begin{array}{l}\text { Windows (number, orientation, total } \\
\text { area }\left[\mathrm{m}^{2}\right] \text { ) }\end{array}$ & 4 , south, 60 & 4, north, 60 \\
\hline \multicolumn{3}{|l|}{$\begin{array}{l}\text { Number of temperature } \\
\text { measurement points }\end{array}$} \\
\hline Roof top & 3 & Same \\
\hline Roof bottom & 2 & Same \\
\hline Inside air & 1 (at $1.7 \mathrm{~m}$ above floor) & Same \\
\hline
\end{tabular}


Table 19. Properties of sensors installed in Foshan factory.

\begin{tabular}{|c|c|}
\hline \multirow{2}{*}{$\begin{array}{l}\text { Measurement } \\
\text { Roof top, roof bottom, room } \\
\text { air temperatures }\end{array}$} & Details \\
\hline & \\
\hline Make and model & Omega TT K-30 thermocouple \\
\hline Accuracy $(\mathrm{K})$ & Unknown $^{\mathrm{a}}$ \\
\hline \multicolumn{2}{|l|}{$\begin{array}{l}\text { Global horizontal solar } \\
\text { irradiance }\end{array}$} \\
\hline Make and model & $\begin{array}{l}\text { Jinzhou Sunshine Technology Development TBQ-2 } \\
\text { pyranometer }\end{array}$ \\
\hline $\begin{array}{l}\text { Accuracy }\left(\mathrm{W} \mathrm{m}^{-2}, \% \text {, or }\right. \\
\text { both) }\end{array}$ & $\begin{array}{l}\text { Unclear; see } \\
\text { http://www.1718w.com/taiyangfusheji2/TBQ-2-B.html }\end{array}$ \\
\hline
\end{tabular}

${ }^{a}$ All thermocouples were calibrated in a water bath to a mercury thermometer with a nominal accuracy of $0.05 \mathrm{~K}$.

Table 21. National Chinese building energy efficiency standards.

\begin{tabular}{|c|c|c|c|c|c|}
\hline Standard & \multicolumn{4}{|c|}{$\begin{array}{l}\text { Maximum roof thermal } \\
\text { transmittance } U\left(\mathrm{~W} \mathrm{~m}^{-2} \mathrm{~K}^{-1}\right)\end{array}$} & Cool surface credit \\
\hline $\begin{array}{l}\text { Design Standard for } \\
\text { Energy Efficiency of } \\
\text { Residential Buildings in } \\
\text { Hot Summer and } \\
\text { Warm Winter Zones - } \\
\text { JGJ75-2012 } \\
\text { (MOHURD 2012) }\end{array}$ & \multicolumn{4}{|c|}{$\begin{array}{l}0.9 \\
\text { Note: if } 0.4 \leq U \leq 0.9 \text {, then 'thermal } \\
\text { interia' } D \text { must be at least } 2.5\end{array}$} & $\begin{array}{l}\text { Roof with solar } \\
\text { absorptance } \alpha<0.6 \\
\text { assigned additional } \\
\text { thermal resistance }\left(\mathrm{m}^{2}\right. \\
\left.\mathrm{K} \mathrm{W}^{-1}\right): \\
0.20 \text { if } \alpha<0.4 \\
0.15 \text { if } 0.4 \leq \alpha<0.6 \\
\\
\text { Roof with vegetation } \\
\text { credited with additional } \\
\text { thermal resistance } 0.9 \\
\left(\mathrm{~m}^{2} \mathrm{~K} \mathrm{~W}^{-1}\right)\end{array}$ \\
\hline $\begin{array}{l}\text { Design Standard for } \\
\text { Energy Efficiency of } \\
\text { Residential Buildings in } \\
\text { Hot Summer and Cold } \\
\text { Winter Zones - } \\
\text { JGJ134-2010 } \\
\text { (MOHURD 2010a) }\end{array}$ & \multicolumn{4}{|c|}{$\begin{array}{l}\text { If shape coefficient } \leq 0.4 \text { : } \\
\quad 0.8 \text { if } D \leq 2.5 \text {, otherwise } 1.0 \\
\text { Else: } \\
\quad 0.5 \text { if } D \leq 2.5 \text {, otherwise } 0.6\end{array}$} & $\begin{array}{l}\text { None, but light-colored } \\
\text { surfaces recommended } \\
\text { for 'heat insulation'; } \\
\text { roofs with vegetation or } \\
\text { surface coatings } \\
\text { recommended for the } \\
\text { southern regions }\end{array}$ \\
\hline \multirow{5}{*}{$\begin{array}{l}\text { Design Standards for } \\
\text { Energy Efficiency of } \\
\text { Residential Buildings in } \\
\text { Cold and Severe Cold } \\
\text { Zones - JGJ26-2010 } \\
\text { (MOHURD 2010b) }\end{array}$} & Climate/Floors & $\leq 3$ & $\begin{array}{l}4- \\
8\end{array}$ & $\geq 9$ & \multirow[t]{5}{*}{ None } \\
\hline & Severe cold A & 0.20 & 0.25 & 0.25 & \\
\hline & Severe cold B & 0.25 & 0.30 & 0.30 & \\
\hline & Severe cold C & 0.30 & 0.40 & 0.40 & \\
\hline & Cold A & 0.35 & 0.45 & 0.45 & \\
\hline
\end{tabular}




\section{Do not use graphics embedded in this document}

\begin{tabular}{|c|c|c|c|c|}
\hline & Cold B & 0.35 & \begin{tabular}{l|l|}
0.45 & 0.45 \\
\end{tabular} & \\
\hline \multirow{6}{*}{$\begin{array}{l}\text { Design Standard for } \\
\text { Energy Efficiency of } \\
\text { Public Buildings - } 2005 \\
\text { (MOHURD 2005) }\end{array}$} & $\begin{array}{l}\text { Climate/Shape } \\
\text { coefficient }^{\mathrm{a}}\end{array}$ & $\leq 0.3$ & $\begin{array}{l}0.3- \\
0.4^{\mathrm{b}}\end{array}$ & \multirow[t]{6}{*}{ None } \\
\hline & Severe cold A & 0.35 & 0.30 & \\
\hline & Severe cold B & 0.45 & 0.35 & \\
\hline & Cold & 0.55 & 0.45 & \\
\hline & $\begin{array}{l}\text { Hot summer, } \\
\text { cold winter }\end{array}$ & \multicolumn{2}{|r|}{0.7} & \\
\hline & $\begin{array}{l}\text { Hot summer, } \\
\text { warm winter }\end{array}$ & \multicolumn{2}{|r|}{0.9} & \\
\hline $\begin{array}{l}\text { Evaluation Standard for } \\
\text { Green Building, GB/T } \\
\text { 50378-2006 (MOHURD } \\
\text { 2006) }\end{array}$ & \multicolumn{3}{|l|}{ N/A } & $\begin{array}{l}\text { None, but reasonable } \\
\text { use of vegetation on } \\
\text { roofs or exterior } \\
\text { surfaces for public } \\
\text { buildings encouraged }\end{array}$ \\
\hline
\end{tabular}

\footnotetext{
${ }^{\text {a }}$ Shape coefficient $\left(\mathrm{m}^{-1}\right)$ is the ratio of building envelope surface area to building volume.
}

${ }^{b}$ If the shape coefficient exceeds 0.4 , the performance compliance method must be used. 
Table 23. Local building energy efficiency standards for residential buildings.

\begin{tabular}{|c|c|c|c|}
\hline Standard & $\begin{array}{l}\text { Maximum roof } \\
\text { thermal } \\
\text { transmittance } U(\mathrm{~W} \\
\left.\mathrm{m}^{-2} \mathrm{~K}^{-1}\right)\end{array}$ & Cool surface credit & Climate \\
\hline $\begin{array}{l}\text { Design Standard for } \\
\text { Energy Efficiency } \\
(65 \%) \text { of Residential } \\
\text { Buildings in } \\
\text { Chongqing } \\
\text { DBJ50-071-2010 } \\
\text { (CCUSC 2010a) }\end{array}$ & $\begin{array}{l}\text { If shape coefficient } \\
\leq 0.4 \text { : } \\
0.6 \text { if } D<2.5, \\
\text { otherwise } 0.8 \\
\text { Else: } \\
0.5 \text { if } D<2.5, \\
\text { otherwise } 0.6\end{array}$ & $\begin{array}{l}\text { Thermal } \\
\text { transmittance } U^{\prime} \text { of } \\
\text { light-colored external } \\
\text { wall }^{a} \text { is multiplied by } \\
0.85 \text { if } U^{\prime}>1.3 \\
0.90 \text { if } 1.0<U^{\prime} \leq 1.3 \\
0.95 \text { if } U^{\prime} \leq 1.0\end{array}$ & $\begin{array}{l}\text { Hot summer and } \\
\text { cold winter }\end{array}$ \\
\hline $\begin{array}{l}\text { Design Standard for } \\
\text { Energy Efficiency } \\
\text { (50\%) of Residential } \\
\text { Buildings in } \\
\text { Chongqing } \\
\text { DBJ50-102-2010 } \\
\text { (CCUSC 2010b) }\end{array}$ & $\begin{array}{l}\text { If shape coefficient is } \\
\leq 0.4 \text { : } \\
0.8 \text { if } D<2.5 \\
\text { otherwise } 1.0 \\
\text { Else: } \\
0.6 \text { if } D<2.5 \\
\text { otherwise } 0.8\end{array}$ & $\begin{array}{l}\text { Thermal } \\
\text { transmittance } U^{\prime} \text { of } \\
\text { light-colored external } \\
\text { wall }^{2} \text { is multiplied by } \\
0.85 \text { if } U^{\prime}>1.3 \\
0.90 \text { if } 1.0<U^{\prime} \leq 1.3 \\
0.95 \text { if } U^{\prime} \leq 1.0 \\
\end{array}$ & $\begin{array}{l}\text { Hot summer and } \\
\text { cold winter }\end{array}$ \\
\hline $\begin{array}{l}\text { Design Standard for } \\
\text { Energy Efficiency of } \\
\text { Residential } \\
\text { Buildings (Shanghai) } \\
\text { DGJ08-205-2011 } \\
\text { (SHCUSCT 2011) }\end{array}$ & $\begin{array}{l}\text { Three-story and } \\
\text { under: } \\
0.5 \text { for light roofs } \\
\quad\left(<200 \mathrm{~kg} / \mathrm{m}^{2}\right) \\
\text { otherwise } 0.6 \\
\text { Four-story or taller: } \\
0.7 \text { for light roofs, } \\
\text { otherwise } 0.8\end{array}$ & $\begin{array}{l}\text { When solar } \\
\text { reflectance is } \geq 0.9, \\
\text { thermal transmittance } \\
U^{\prime} \text { of light-color } \\
\text { external wall or roof is } \\
\text { multiplied } \\
\text { by } \\
0.85 \text { if } U^{\prime} \geq 1.4 \\
0.86 \text { if } 1.1 \leq U^{\prime}<1.4 \\
0.87 \text { if } U^{\prime}<1.1 \\
\\
\text { When solar } \\
\text { reflectance is } 0.8 \text { - } \\
0.9, U^{\prime} \text { is multiplied by } \\
0.90 \text { if } U^{\prime} \geq 1.4 \\
0.91 \text { if } 1.1 \leq U^{\prime}<1.4 \\
0.92 \text { if } U^{\prime}<1.1\end{array}$ & $\begin{array}{l}\text { Hot summer and } \\
\text { cold winter }\end{array}$ \\
\hline $\begin{array}{l}\text { Design Standard for } \\
\text { Energy Efficiency of } \\
\text { Civil Buildings in } \\
\text { Yunnan Province, } \\
\text { DBJ 53/T-39-2011 } \\
\text { (YCUSC 2011) }\end{array}$ & $\begin{array}{l}1.8 \text { if } D \geq 3 \\
1.5 \text { if } 2.5 \leq D<3 \\
\text { Otherwise } 1.2\end{array}$ & $\begin{array}{l}\text { None, but light- } \\
\text { colored surfaces, } \\
\text { vegetation } \\
\text { recommended for } \\
\text { roofs and east/west } \\
\text { walls } \\
\end{array}$ & $\begin{array}{l}\text { Temperate } \\
\text { regions }\end{array}$ \\
\hline Design Standard for & 1.0 if $\mathrm{D} \geq 2.5$ & Thermal resistance & Hot summer and \\
\hline
\end{tabular}


Do not use graphics embedded in this document

\begin{tabular}{|l|l|l|l|}
\hline $\begin{array}{l}\text { Energy Efficiency of } \\
\text { Residential } \\
\text { Buildings-Hainan } \\
\text { Province }\end{array}$ & otherwise 0.5 & value is increased by & warm winter \\
JDJ01-2005 (HCC & 0.2 for light-colored \\
2005) & external wall or roof; & \\
& & $\begin{array}{l}0.3 \text { to } 0.5 \text { for roofs } \\
\text { that include one or } \\
\text { more of the following } \\
\text { measures: radiant } \\
\text { barrier; roof covered } \\
\text { by water storage, } \\
\text { green plants, or } \\
\text { shades; }\end{array}$ & \\
& & $\begin{array}{l}0.3 \text { for west/east } \\
\text { walls that are covered } \\
\text { by green plants }\end{array}$ & \\
\hline
\end{tabular}

a Light colors are recommended to reduce the solar heat gains of both roofs and external walls, but only light-colored walls receive credit. 
Table 25. Local energy efficiency standards for public buildings.

\begin{tabular}{|c|c|c|c|}
\hline Standard & $\begin{array}{l}\text { Maximum roof } \\
\text { thermal } \\
\text { transmittance } U(W \\
\left.m^{-2} K^{-1}\right)\end{array}$ & Cool surface credit & Climate \\
\hline $\begin{array}{l}\text { Design Standard for } \\
\text { Energy Efficiency of } \\
\text { Public Buildings in } \\
\text { Chongqing (CCC } \\
\text { 2006) }\end{array}$ & $\begin{array}{l}0.7 \text { for light roofs } \\
\text { (metal or wood), } \\
\text { otherwise } 0.5\end{array}$ & $\begin{array}{l}\text { None, but light- } \\
\text { colored surfaces with } \\
\text { low solar absorptance } \\
\text { and high thermal } \\
\text { emittance are } \\
\text { recommend for walls } \\
\text { and roofs }\end{array}$ & $\begin{array}{l}\text { Hot summer and } \\
\text { cold winter }\end{array}$ \\
\hline $\begin{array}{l}\text { Design Standard for } \\
\text { Energy Efficiency of } \\
\text { Public Buildings } \\
\text { (Shanghai) } \\
\text { DGJ 08-107-2012 } \\
\text { (SHCUSCT 2012) }\end{array}$ & $\begin{array}{l}\text { Type A buildings } \\
\text { (floor area }>5000 \mathrm{~m}^{2} \\
\text { with central system): } \\
0.5 \text {, or } 0.4 \text { for } \\
\text { light roofs }(<200 \\
\left.\mathrm{kg} / \mathrm{m}^{2}\right) \\
\\
\text { Type B buildings } \\
\text { (floor area }<5000 \mathrm{~m}^{2} \text {, } \\
\text { no central HVAC } \\
\text { system): } \\
0.6, \text { or } 0.5 \text { for } \\
\text { light roofs } \\
\text { All building types: } \\
2.8 \text { if no more } \\
10 \% \text { of total roof } \\
\text { area is } \\
\text { transparent } \\
2.5 \text { if } 10-20 \% \text { of } \\
\text { total roof area is } \\
\text { transparent }\end{array}$ & $\begin{array}{l}\text { When solar } \\
\text { reflectance is } \geq 0.9, \\
\text { thermal transmittance } \\
U^{\prime} \text { of light-color } \\
\text { external wall and roof } \\
\text { is multiplied } \\
\text { by } \\
0.85 \text { if } U^{\prime} \geq 1.4 \\
0.86 \text { if } 1.1 \leq U^{\prime}<1.4 \\
0.87 \text { if } U^{\prime}<1.1 \\
\text { When solar } \\
\text { reflectance is } 0.8- \\
0.9, U^{\prime} \text { is multiplied by } \\
0.90 \text { if } U^{\prime} \geq 1.4 \\
0.91 \text { if } 1.1 \leq U^{\prime}<1.4 \\
0.92 \text { if } U^{\prime}<1.1\end{array}$ & $\begin{array}{l}\text { Hot summer and } \\
\text { cold winter }\end{array}$ \\
\hline $\begin{array}{l}\text { Design Standard for } \\
\text { Energy Efficiency of } \\
\text { Public Buildings in } \\
\text { Jiangsu Province } \\
\text { DGJ32 J 96-2010 } \\
\text { (JCHC 2010) }\end{array}$ & $\begin{array}{l}\text { Hot summer and cold } \\
\text { winter regions } \\
\text { Type A buildings } \\
\text { (floor area }>20,000 \\
\mathrm{~m}^{2}, \text { with central } \\
\text { HVAC): } \\
\quad 0.6 \\
\text { Type B buildings }\end{array}$ & $\begin{array}{l}\text { None, but roof plants } \\
\text { or insulated layers } \\
\text { are recommended for } \\
\text { flat roofs }\end{array}$ & $\begin{array}{l}\text { Hot summer and } \\
\text { cold winter }\end{array}$ \\
\hline
\end{tabular}




\begin{tabular}{|c|c|c|c|}
\hline & $\begin{array}{l}\begin{array}{l}\text { (floor area }<20,000 \\
\left.\mathrm{~m}^{2}\right):\end{array} \\
0.7 \\
\text { Cold regions } \\
\text { Type A buildings } \\
\text { (floor area }>20,000 \\
\mathrm{~m}^{2} \text {, with central } \\
\text { HVAC): } \\
0.45 \text { when shape } \\
\text { coefficient is } \leq \\
0.30 \\
0.35 \text { when shape } \\
\text { coefficient is }> \\
0.3 \text { but } \leq 0.4 \\
\\
\text { Type } \mathrm{B} \text { buildings } \\
(\text { floor area }<20,000 \\
\left.\mathrm{m}^{2}\right): \\
0.55 \text { when shape } \\
\text { coefficient is } \leq \\
0.30 ; \\
0.45 \text { when shape } \\
\text { coefficient is }> \\
0.3 \text { but } \leq 0.4\end{array}$ & & \\
\hline $\begin{array}{l}\text { Design Standard for } \\
\text { Energy Efficiency of } \\
\text { Public Buildings in } \\
\text { Hainan Province } \\
\text { JBJ03-2006 (HCC } \\
\text { 2006) }\end{array}$ & $\begin{array}{l}0.9 \text { for opaque } \\
\text { elements } \\
3.5 \text { for transparent } \\
\text { elements (no more } \\
\text { than } 20 \% \text { of total roof } \\
\text { area) with SHGC no } \\
\text { more than } 0.35\end{array}$ & None & $\begin{array}{l}\text { Hot summer and } \\
\text { warm winter }\end{array}$ \\
\hline
\end{tabular}

Table 27. Annual heating degree days, cooling degree days, heating hour insolation, and cooling hour insolation (all base $18^{\circ} \mathrm{C}$ ) of four U.S. cities representative of ASHRAE climate zones.

\begin{tabular}{|l|l|l|l|l|}
\hline & HDD18C & CDD18C & $\begin{array}{l}\mathrm{HHI18C} \\
\left(\mathrm{kWh} / \mathrm{m}^{2}\right)\end{array}$ & $\begin{array}{l}\mathrm{CHI18C} \\
\left(\mathrm{kWh} / \mathrm{m}^{2}\right)\end{array}$ \\
\hline Duluth, MN (7) & 5577 & 172 & 927 & 422 \\
\hline Baltimore, MD (4A) & 2716 & 750 & 610 & 872 \\
\hline Atlanta, GA (3A) & 1750 & 972 & 512 & 1189 \\
\hline Las Vegas, NV (3B- & 1344 & 1902 & 516 & 1559 \\
\hline
\end{tabular}


Do not use graphics embedded in this document

other) 
Table 29. Ratio of annual heating degree days, cooling degree days, heating hour insolation, and cooling hour insolation (all base $18^{\circ} \mathrm{C}$ ) of four U.S. cities to Chinese cities with comparable heating and/or cooling degree days.

\begin{tabular}{|l|l|l|l|l|}
\hline & HDD18C ratio & CDD18C ratio & HHI18C ratio & CHI18C ratio \\
\hline Duluth/Harbin & 1.01 & 0.40 & 1.29 & 0.76 \\
\hline Baltimore/Beijing & 0.94 & 0.81 & 1.01 & 1.09 \\
\hline Atlanta/Shanghai & 1.09 & 0.86 & 1.10 & 1.48 \\
\hline Las Vegas/Guangzhou & 3.01 & 0.96 & 3.20 & 1.60 \\
\hline
\end{tabular}

Table 31. Maximum thermal transmittance $\left(\mathrm{W} \mathrm{m}^{-2} \mathrm{~K}^{-1}\right)$ of building envelope components permitted in various Chinese cities (MOHURD 2003, 2005, 2010a, 2010b).

\begin{tabular}{|l|l|l|l|l|l|l|}
\hline & \multicolumn{3}{|l|}{ Public buildings } & \multicolumn{3}{l|}{ Residential buildings } \\
\hline City & Roof & Wall & Window & Roof & Wall & Window \\
\hline Harbin & 0.35 & 0.45 & 2.8 & 0.25 & 0.4 & 2.0 \\
\hline Changchun & 0.45 & 0.5 & 2.9 & 0.3 & 0.45 & 2.2 \\
\hline Beijing & 0.55 & 0.6 & 3.0 & 0.45 & 0.6 & 2.8 \\
\hline Chongqing & 0.7 & 1.0 & 3.5 & 1.0 & 1.5 & 4.0 \\
\hline Shanghai & 0.7 & 1.0 & 3.5 & 1.0 & 1.5 & 4.0 \\
\hline Wuhan & 0.7 & 1.0 & 3.5 & 1.0 & 1.5 & 4.0 \\
\hline Guangzhou & 0.9 & 1.5 & 4.7 & 1.0 & 1.5 & 5.0 \\
\hline
\end{tabular}

Table 33. Daily heat influx, outflux, and net flux (influx - outflux) through the blue and white roofs of the Foshan factory, averaged over 27 - 31 Aug 2011.

\begin{tabular}{|l|l|l|l|}
\hline & $\begin{array}{l}\text { Blue } \\
\text { roof }\end{array}$ & $\begin{array}{l}\text { White } \\
\text { roof }\end{array}$ & $\begin{array}{l}\text { Reduction (blue - } \\
\text { white) }\end{array}$ \\
\hline $\begin{array}{l}\text { Daily heat influx (Wh m } \\
\text { 2) }\end{array}$ & 33.6 & 17.2 & $16.4[49 \%]$ \\
\hline $\begin{array}{l}\text { Daily heat outflux (Wh } \\
\mathrm{m}^{-2} \text { ) }\end{array}$ & 15.2 & 11.1 & $4.2[27 \%]$ \\
\hline $\begin{array}{l}\text { Daily heat net flux (Wh } \\
\mathrm{m}^{-2} \text { ) }\end{array}$ & 18.4 & 6.19 & $12.2[66 \%]$ \\
\hline
\end{tabular}




\section{Do not use graphics embedded in this document}

\section{References cited in tables}

Cao L, Wang C. 2010. Calculation of $\mathrm{SO}_{2}$ and $\mathrm{NO}_{x}$ emission factors of China's national power grids. China Environmental Science 30 (1), 7-11.

CCC. 2006. Design Standard for Energy Efficiency of Public Buildings in Chongqing. 2006. DBJ50-052-2006. Chongqing Commission of Construction.

CCUSC. 2010a. Design Standard for Energy Efficiency (65\%) of Residential Buildings in Chongqing. 2010. DBJ50-071-2010. Chongqing Commission of Urban and Suburban Construction.

CCUSC. 2010b. Design Standard for Energy Efficiency (50\%) of Residential Buildings in Chongqing. DBJ50-102-2010, Chongqing Commission of Urban and Suburban Construction.

CDRC. 2011. Announcement on regulating the heating price in Changchun urban areas. Changchun Development and Reform Commission.

http://www.ccdrc.gov.cn/ccNEWS.asp?id=7686 .

GAQSIQPRC. 2009. Monitoring and testing for energy saving of coal fired industrial boilers. General Administration of Quality Supervision, Inspection and Quarantine of the People's Republic of China.

HACP. 2012. Announcement on temporary trial on heating usage pricing. Harbin Administration of Commodity Price.

http://www.hrbpb.gov.cn/export/shouye/tztg/gztz/article_0142.html [Last Accessed Dec.27th, 2012].

HCC. 2005. Design Standard for Energy Efficiency of Residential Buildings-Hainan Province JDJ01-2005, Hainan Commission of Construction.

HCC. 2006. Design Standard for Energy Efficiency of Public Buildings in Hainan Province, JBJ03-2006. Hainan Commission of Construction.

JCHC. 2010. Design Standard for Energy Efficiency of Public Buildings in Jiangsu Province, DGJ32 J 96-2010. Jiangsu Commission of Housing and Construction.

MOHURD. 2003. Design Standard for Energy Efficiency of Residential Buildings in Hot Summer and Warm Winter Zones. Ministry of Housing and Urban-Rural Development, People's Republic of China.

MOHURD. 2005. Design Standard for Energy Efficiency of Public Buildings. Ministry of Housing and Urban-Rural Development, People's Republic of China. 


\section{Do not use graphics embedded in this document}

MOHURD. 2006. Evaluation Standard for Green Building, GB/T 50378-2006. Ministry of Housing and Urban-Rural Development, People's Republic of China.

MOHURD. 2009. Heating, Ventilation and Air Conditioning. 1st ed. China Institute of Building Standard Design \& Research. Beijing: China Planning Press.

MOHURD. 2010a. Design Standard for Energy Efficiency of Residential Buildings in Hot Summer and Cold Winter Zones - JGJ134-2010. Ministry of Housing and Urban-Rural Development, People's Republic of China.

MOHURD. 2010b. Design Standards for Energy Efficiency of Residential Buildings in Cold and Severe Cold Zones, JGJ26-2010. Ministry of Housing and Urban-Rural Development, People's Republic of China.

MOHURD. 2012. Design Standard for Energy Efficiency of Residential Buildings in Hot Summer and Warm Winter Zones, JGJ75-2012. Ministry of Housing and Urban-Rural Development, People's Republic of China.

NDRC. 2011a. Announcement on changing the electricity price on the "Southern Grid". National Development and Reform Commission. [2011]2618.

NDRC. 2011b. Announcement on changing the electricity price on the "Northern Grid". National Development and Reform Commission. [2011]2619.

NDRC. 2011c. Announcement on changing the electricity price on the "East Northern Grid". National Development and Reform Commission. [2011]2620.

NDRC. 2011d. Announcement on changing the electricity price on the "West Northern Grid". National Development and Reform Commission. [2011]2621.

NDRC. 2011e. Announcement on changing the electricity price on the "Eastern Grid". National Development and Reform Commission. [2011]2622.

NDRC. 2011f. Announcement on changing the electricity price on the "Central Grid". National Development and Reform Commission. [2011]2623.

NDRC. 2012. 2012 Baseline Emission Factors for Regional Power Grids in China. National Development and Reform Commission, People's Republic of China. http://cdm.ccchina.gov.cn/WebSite/CDM/UpFile/File2975.pdf .

SAPRC. 2010. Room air conditioning energy efficiency standard GB 12021.3-2010. Standardization Administration of the People's Republic of China, General Administration of Quality Supervision, Inspection and Quarantine of the People's Republic of China. http://www.csres.com/detail/209545.html .

SHCUSCT. 2011. Design Standard for Energy Efficiency of Residential Buildings (Shanghai). 2011. DGJ08-205-2011, Shanghai Commission of Urban and Suburban Construction and Transportation. 


\section{Do not use graphics embedded in this document}

SHCUSCT. 2012. Design Standard for Energy Efficiency of Public Buildings (Shanghai), DGJ 08-107-2012. Shanghai Commission of Urban and Suburban Construction and Transportation.

Sun G. 2010. Coal in China: Resources, uses, and advanced coal technologies. Coal Initiative-Pew Center on Global Climate Change, March 2010. Online at http://www.c2es.org/docUploads/coal-in-china-resources-uses-technologies.pdf .

US EIA. 2011. Electric Power Annual (EPA) 2011, Table A-3. U.S. Energy Information Administration. http://www.eia.gov/electricity/annual/html/epa_a_03.html .

US EPA. 1995. Compilation of air pollutant emission factors, Volume I: Stationary point and area sources, AP-42, $5^{\text {th }}$ ed, January. U.S. Environmental Protection Agency. http://www.epa.gov/ttnchie1/ap42 .

US EPA. 2004. Unit conversions, emission factors, and other reference data, November 2004. U.S. Environmental Protection Agency. http://www.epa.gov/cpd/pdf/brochure.pdf .

YCUSC. 2011. Design standard for energy efficiency of civil buildings, DBJ 53/T-392011. Yunnan Commission of Urban and Suburban Construction. 


\section{Figures}

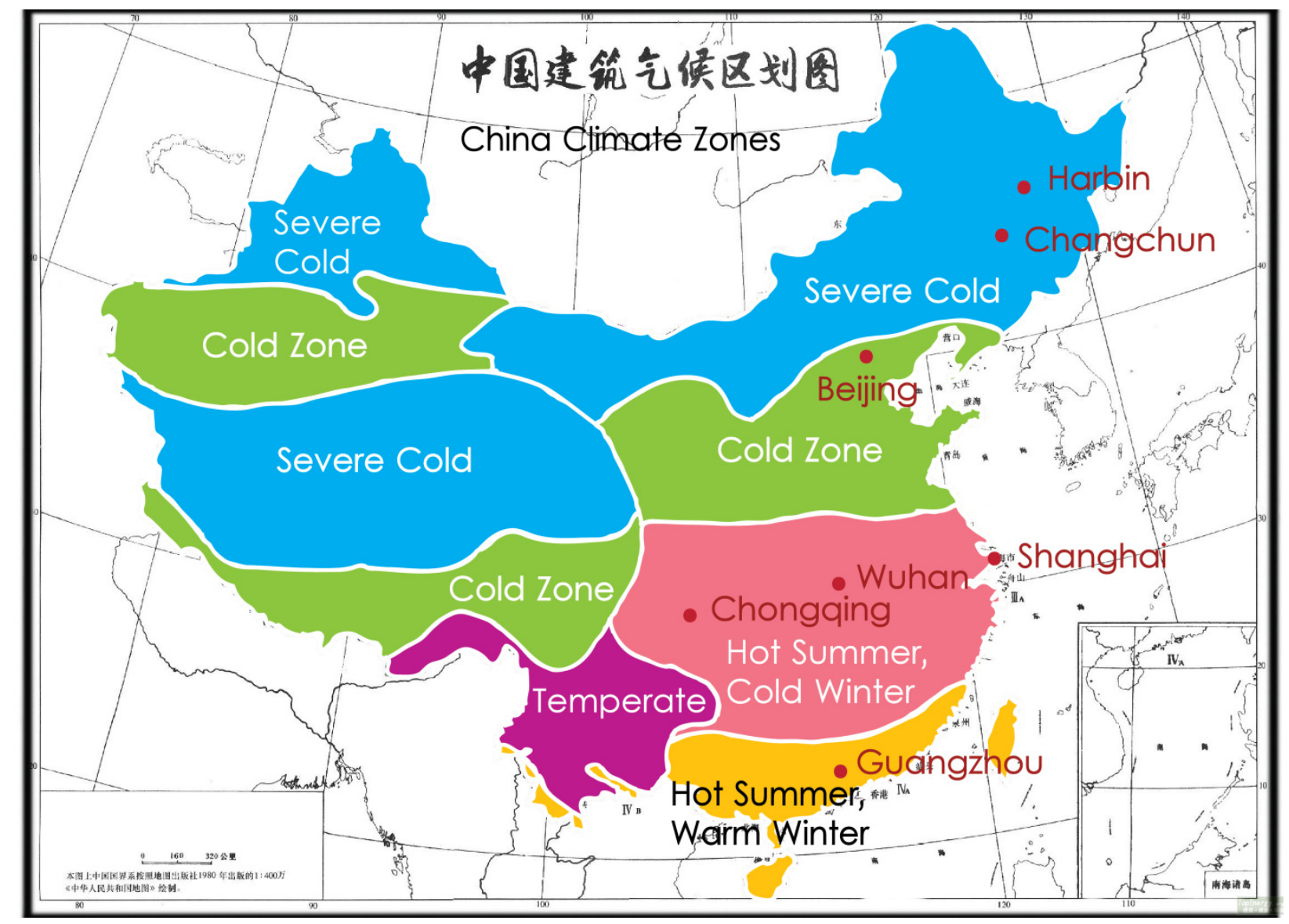

Figure 1. Map of Chinese climates zones and cities, based on MOHURD (1993). 
Do not use graphics embedded in this document

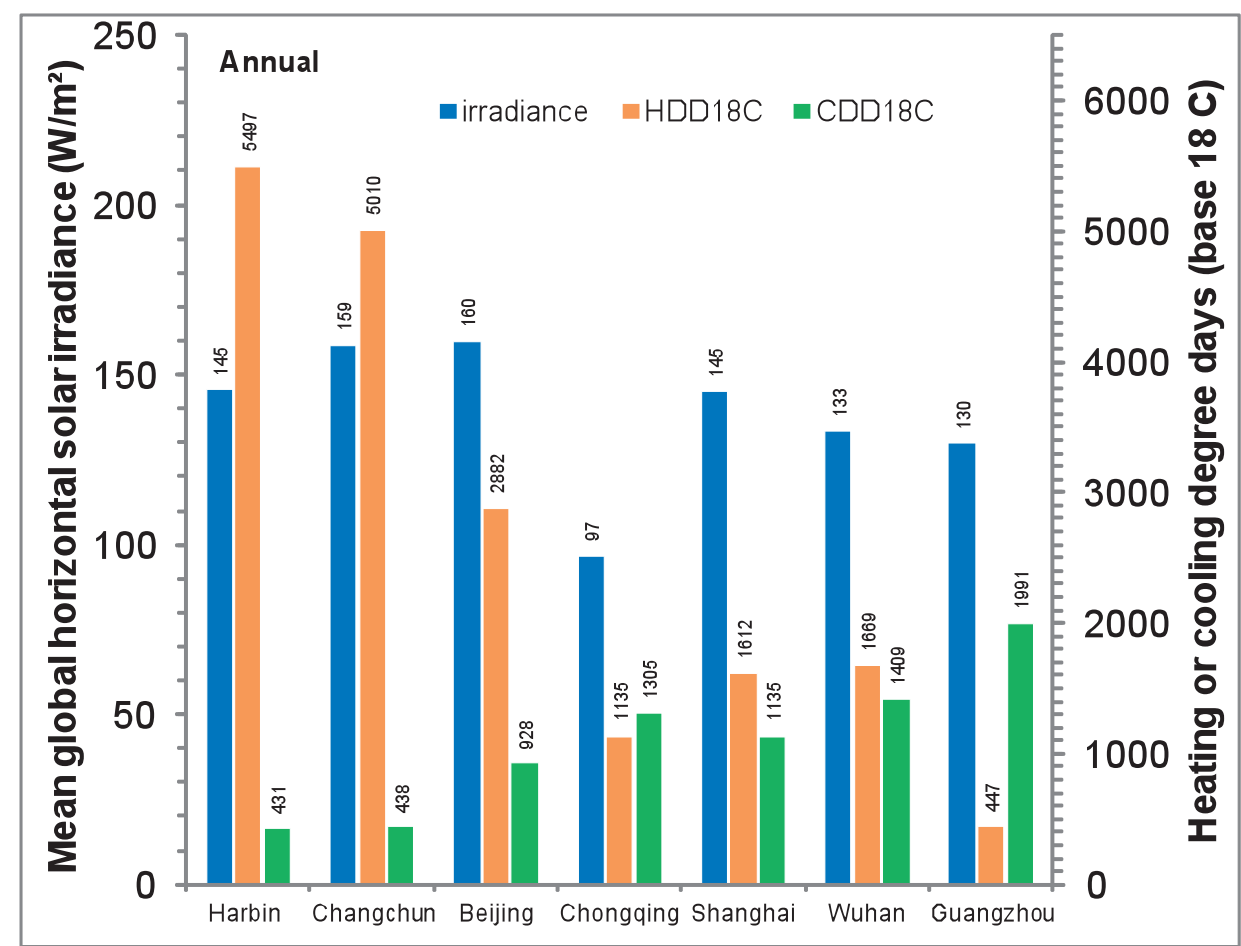

(a)

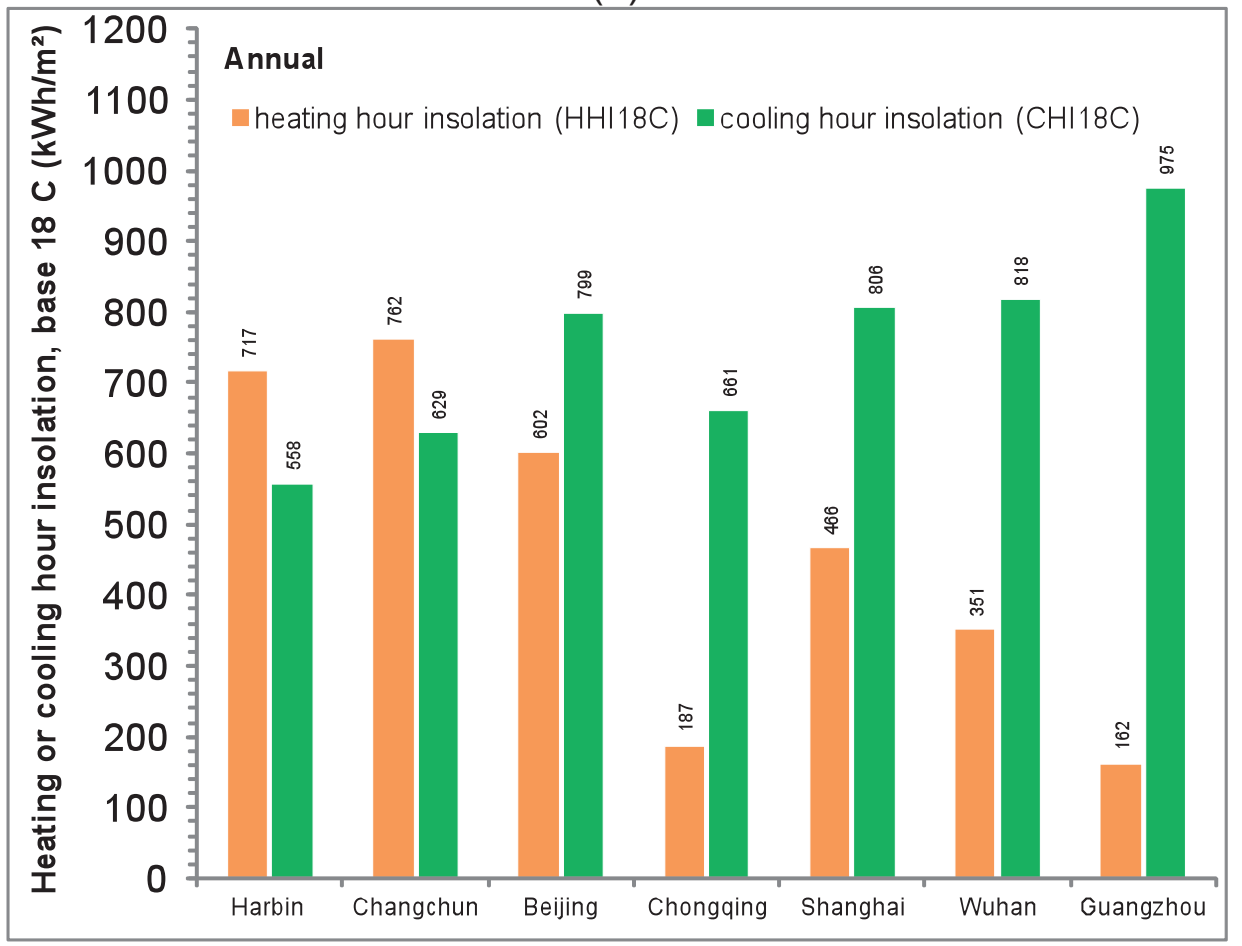

(b)

Figure 3. Annual values in the seven Chinese cities of (a) mean solar irradiance, heating degree days (base $18^{\circ} \mathrm{C}$ ), and cooling degree days (base $18^{\circ} \mathrm{C}$ ); and (b) heating hour insolation and cooling hour insolation (also base $18^{\circ} \mathrm{C}$ ). 


\section{Do not use graphics embedded in this document}

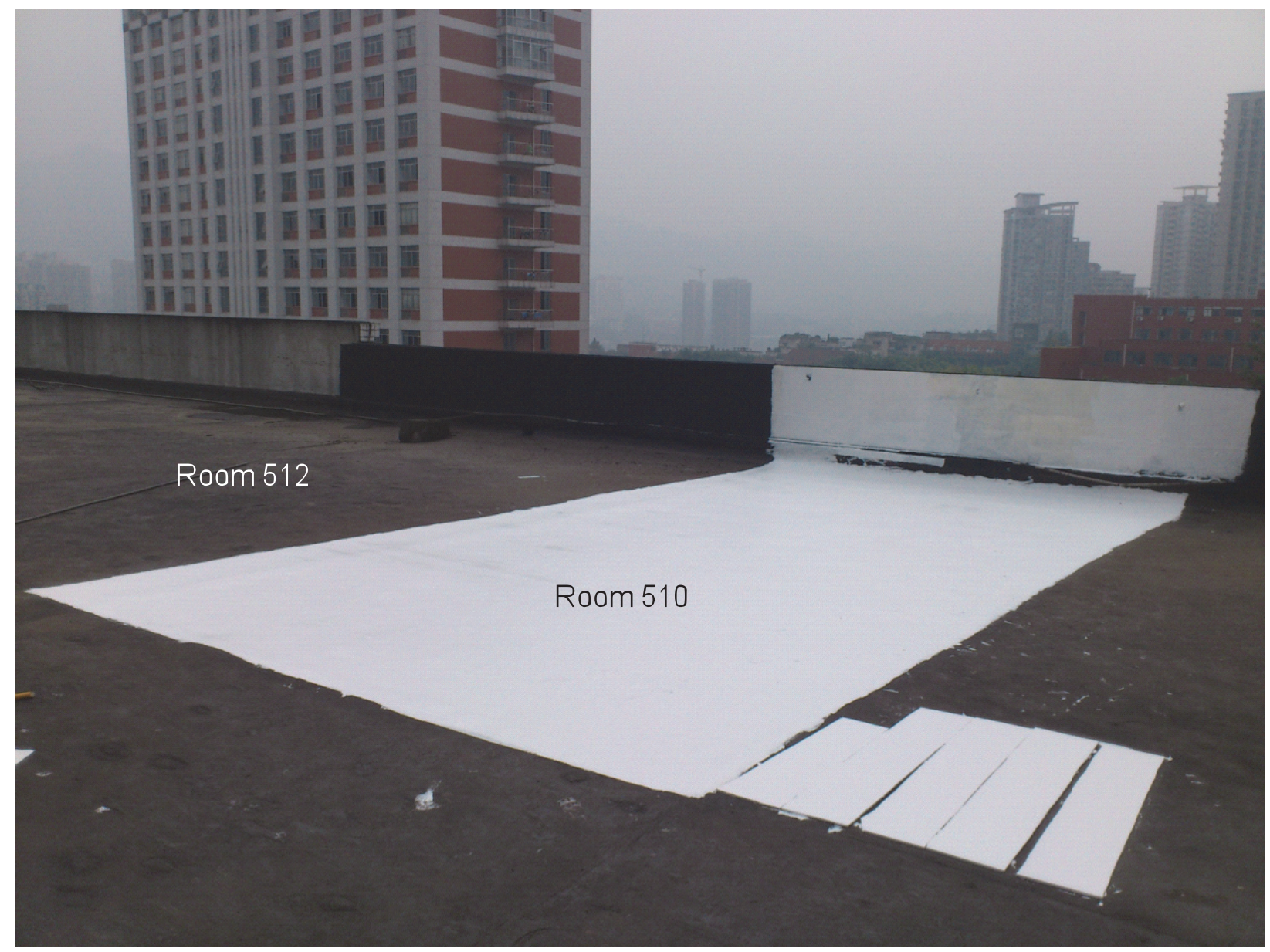

Figure 5. Roof of room 510 with fresh white coating in May 2012. The uncoated roof of room 512 lies immediately left, while to the right a set of coated panels are being exposed for future testing. 
Do not use graphics embedded in this document
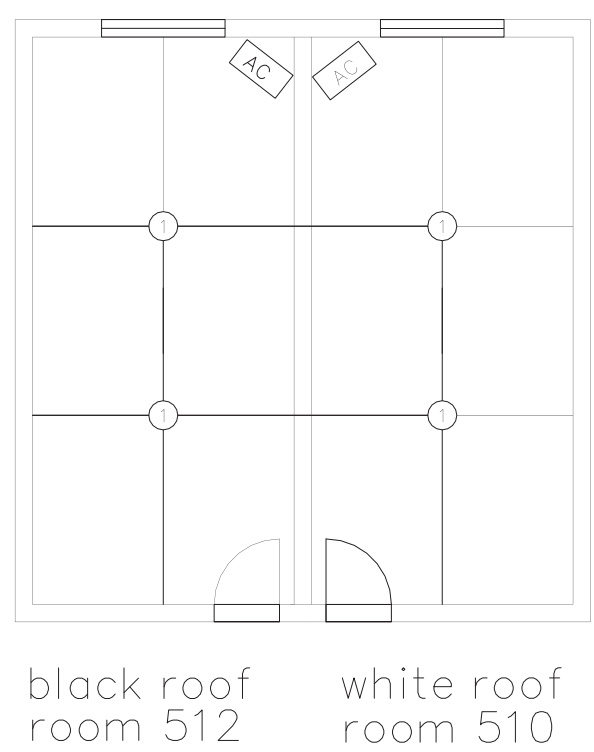

(a)

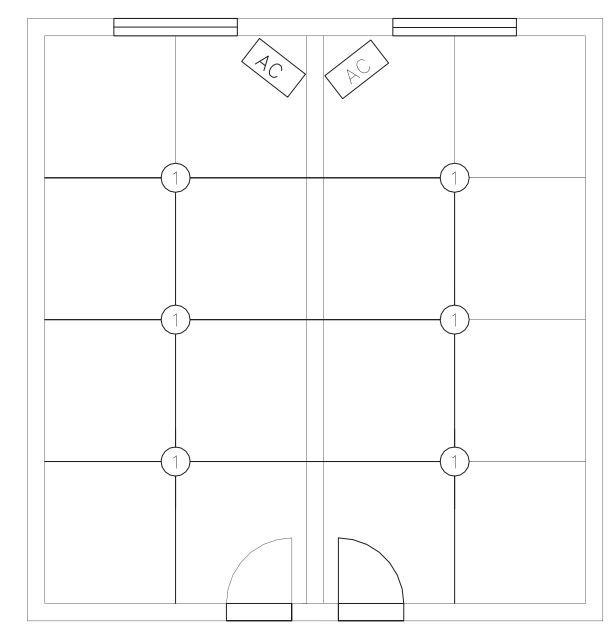

black roof room 512

(c)
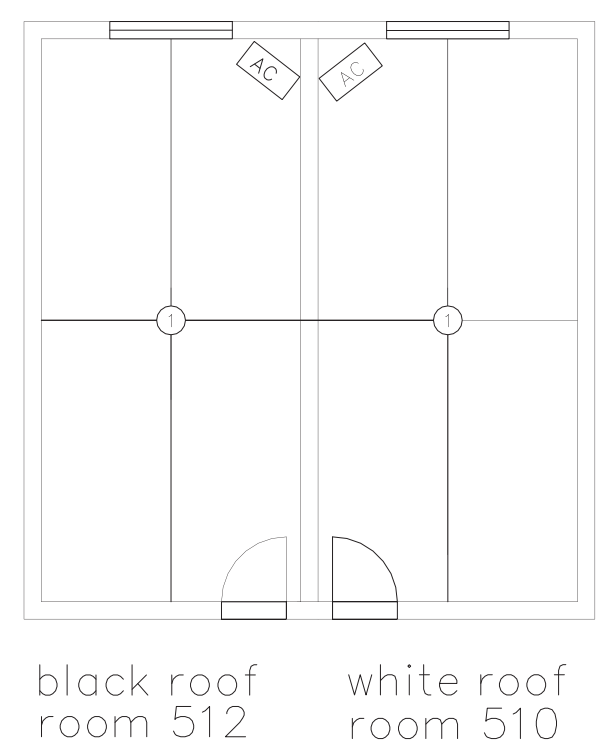

(b)
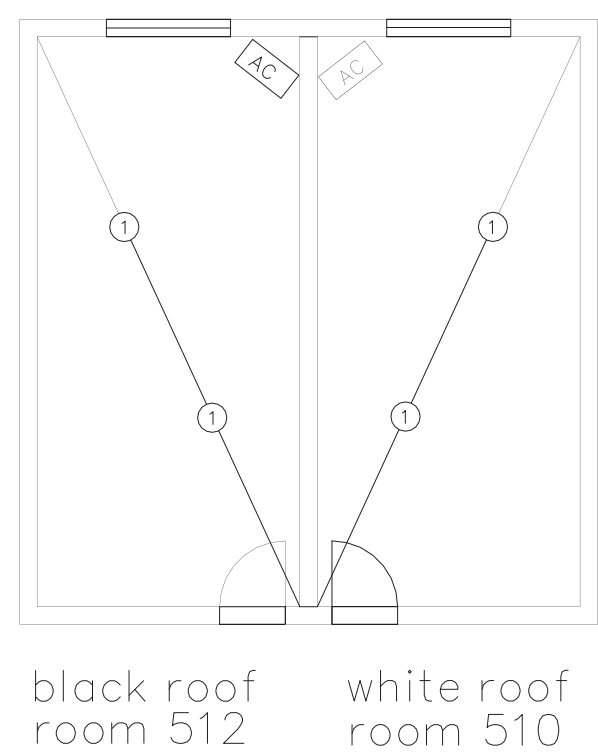

(d)

Figure 7. Locations of (a) roof top temperature, (b) roof bottom temperature, (c) ceiling surface temperature and (d) room air temperature measurements in rooms 510 and 512 of the office building at Chongqing University. 


\section{Do not use graphics embedded in this document}

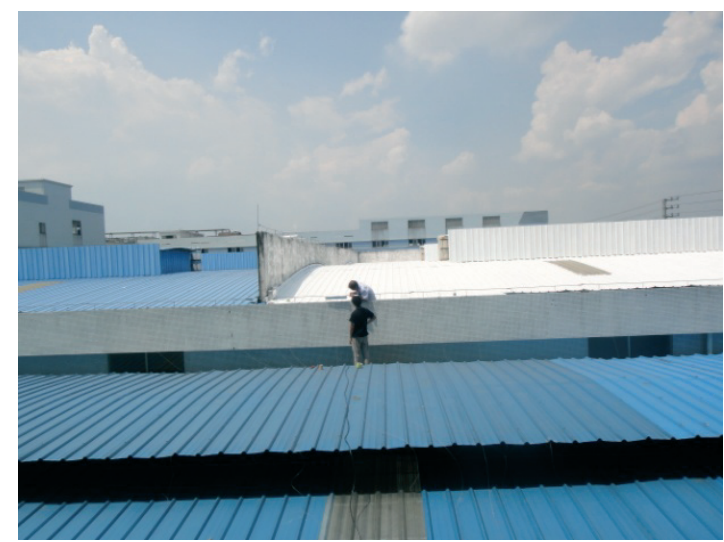

(a)

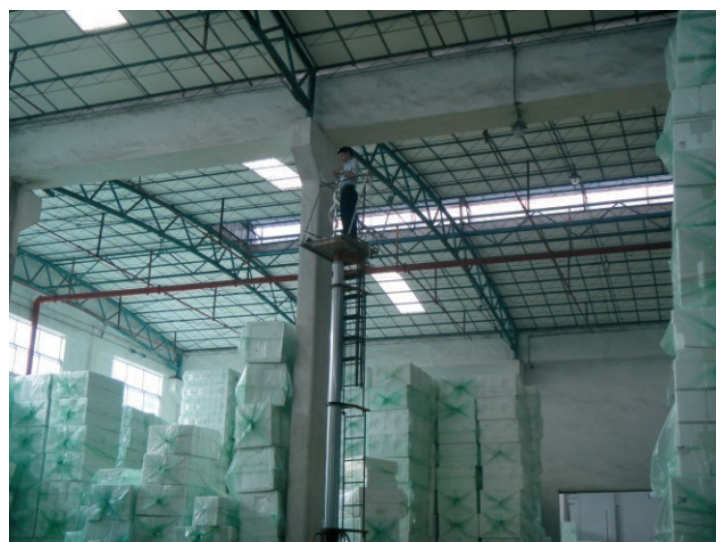

(b)

Figure 9. Images of a naturally ventilated factory in the Shunde district of Foshan (Guangdong), showing (a) original (blue) and cool (white) sections of the metal roof, and (b) the interior of the factory.

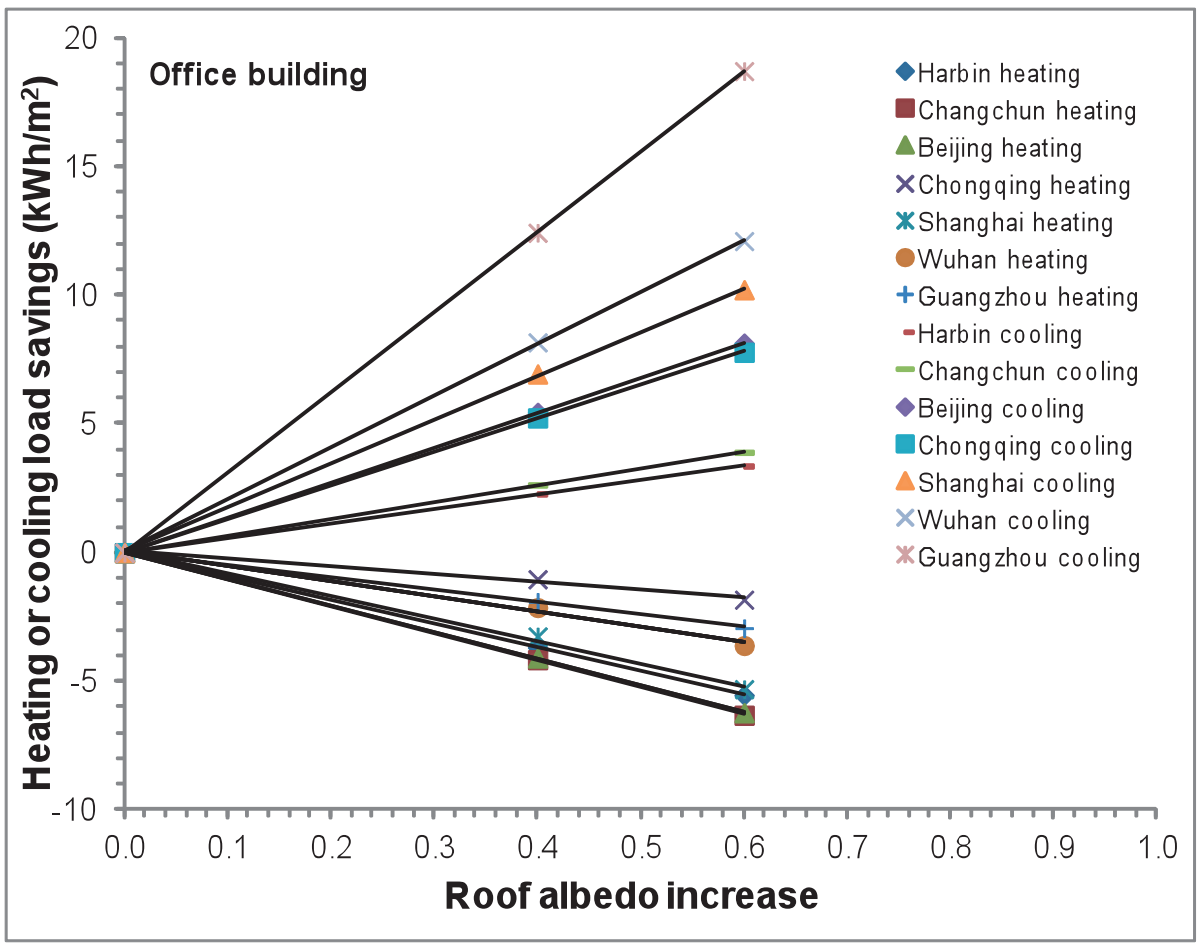

Figure 11. Annual heating and cooling load savings scale linearly with increase in roof albedo of the office building (shown) and residential building (not shown). 


\section{Do not use graphics embedded in this document}

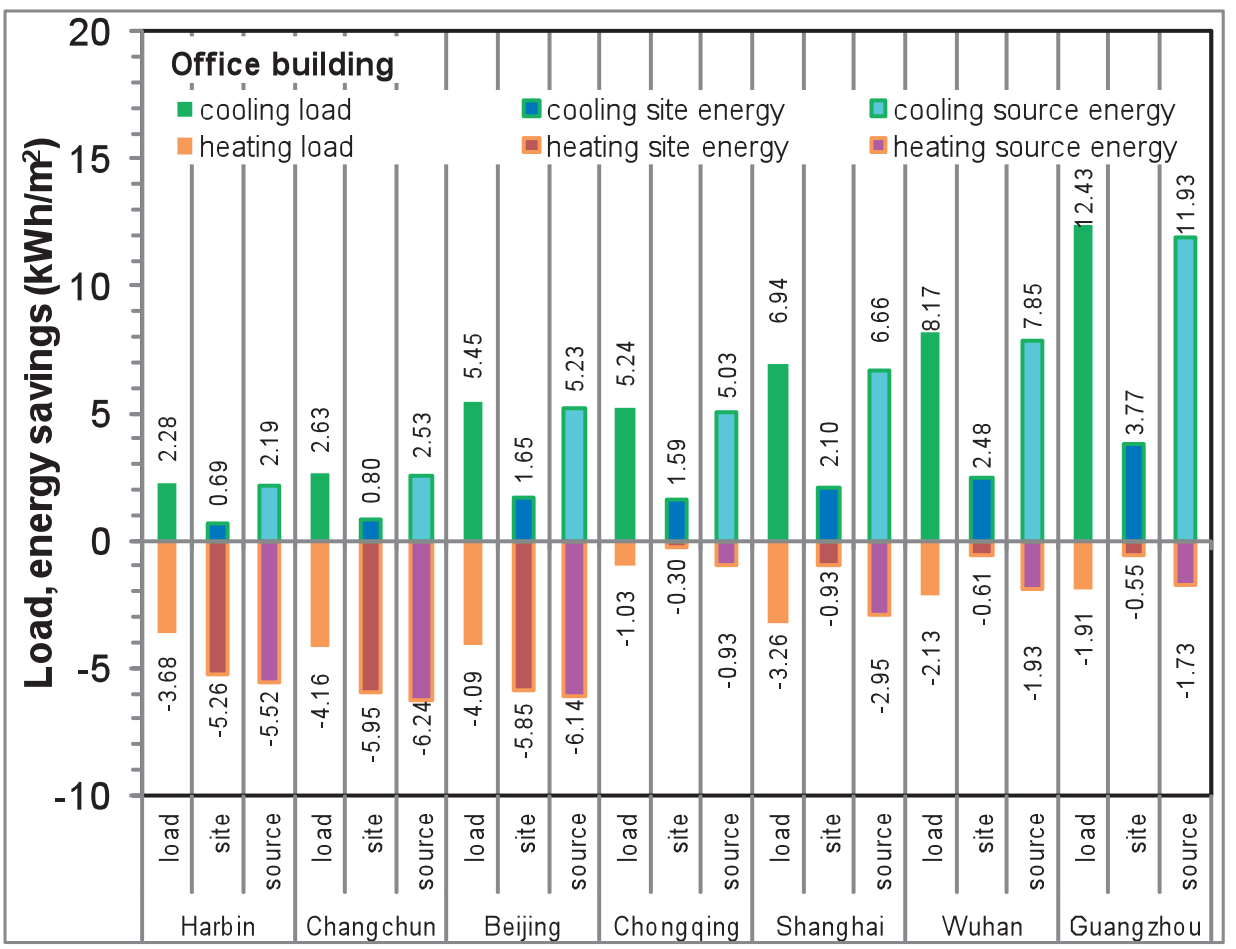

(a)

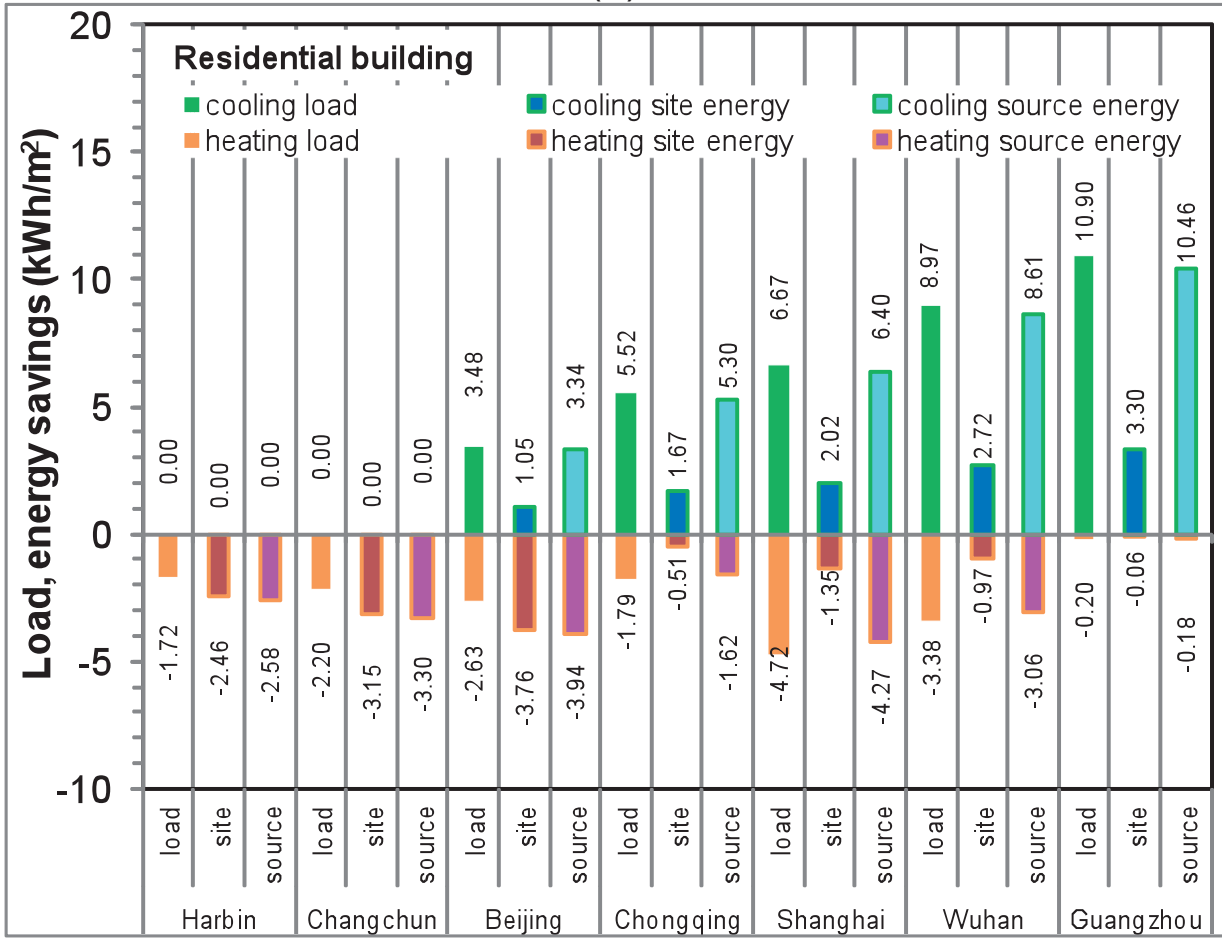

(b)

Figure 13. Annual heating and cooling load, site energy, and source energy savings per unit CRA for (a) the office prototype and (b) the residential prototype, upon increasing roof albedo to 0.6 from 0.2 . 
Do not use graphics embedded in this document

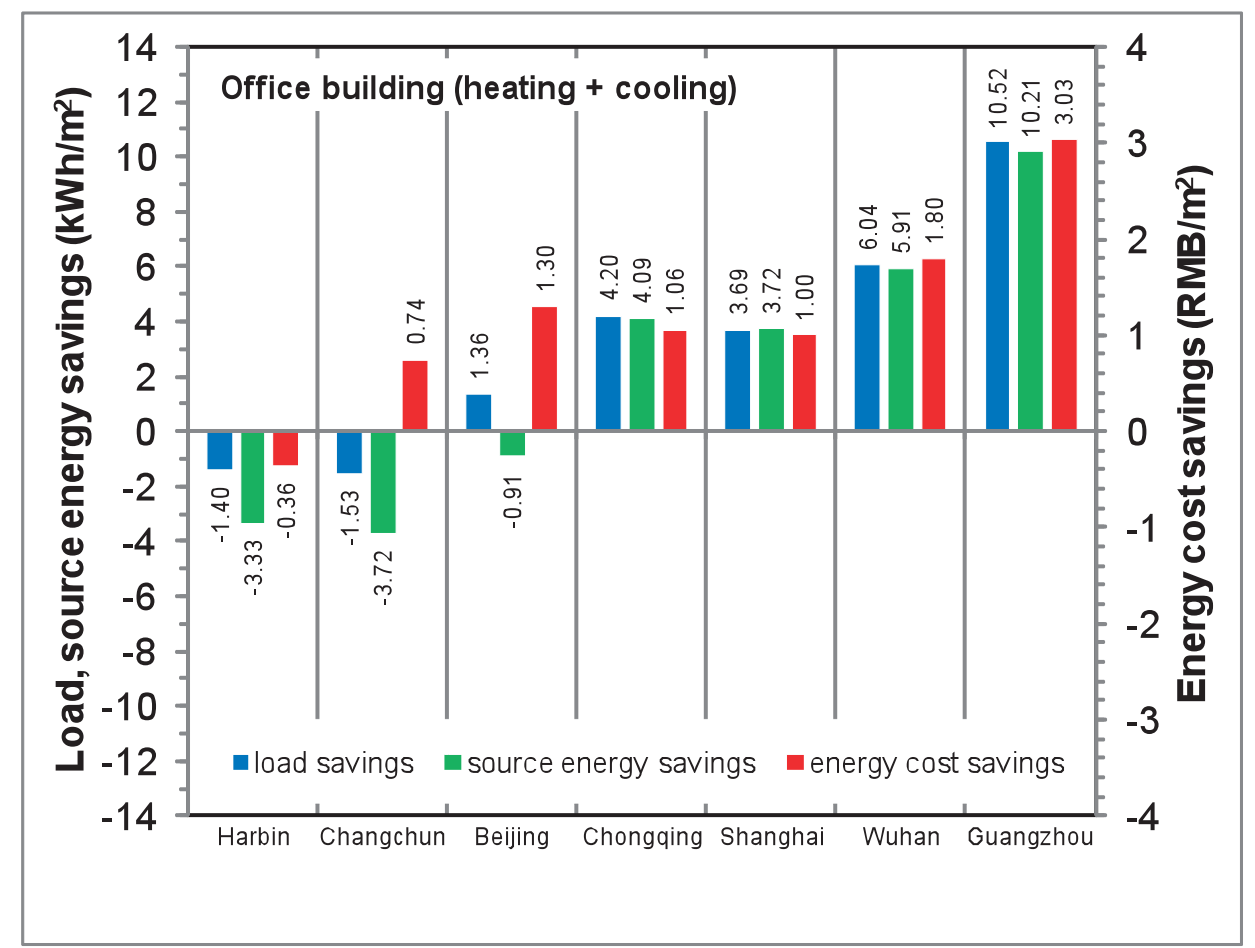

(a)

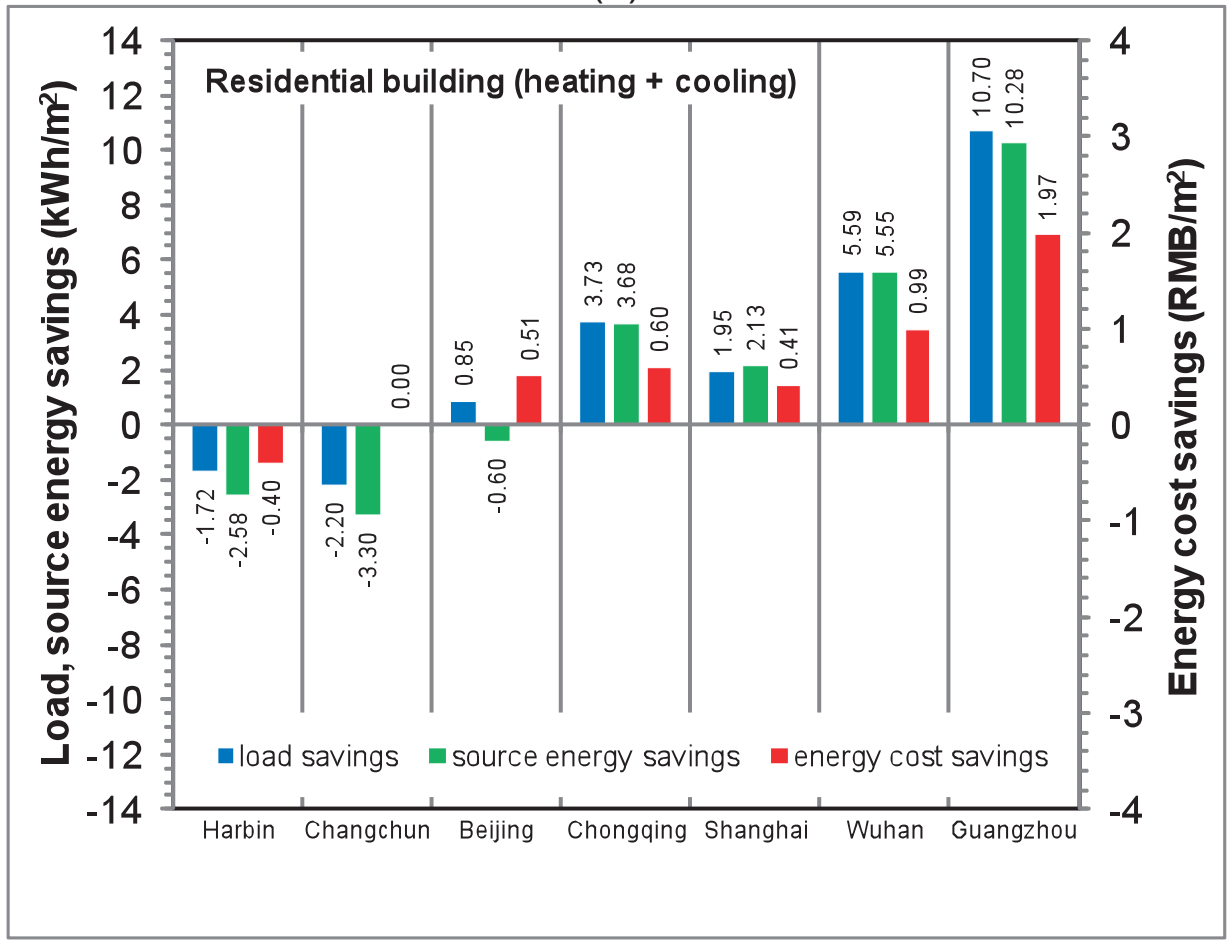

(b)

Figure 15. Annual conditioning (heating + cooling) load, source energy and energy cost savings per unit CRA for (a) the office prototype and (b) the residential prototype, upon increasing roof albedo to 0.6 from 0.2 . 


\section{Do not use graphics embedded in this document}

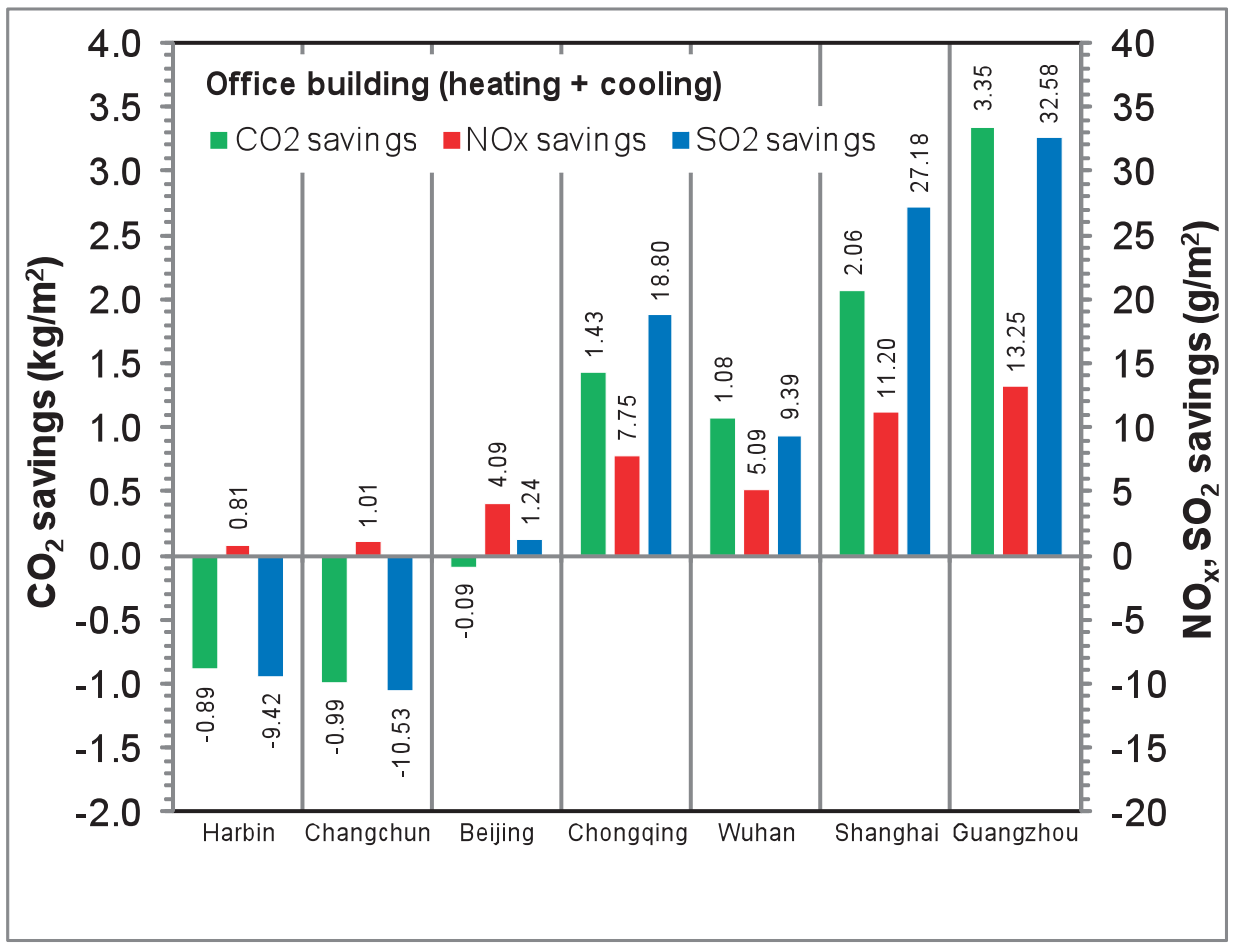

(a)

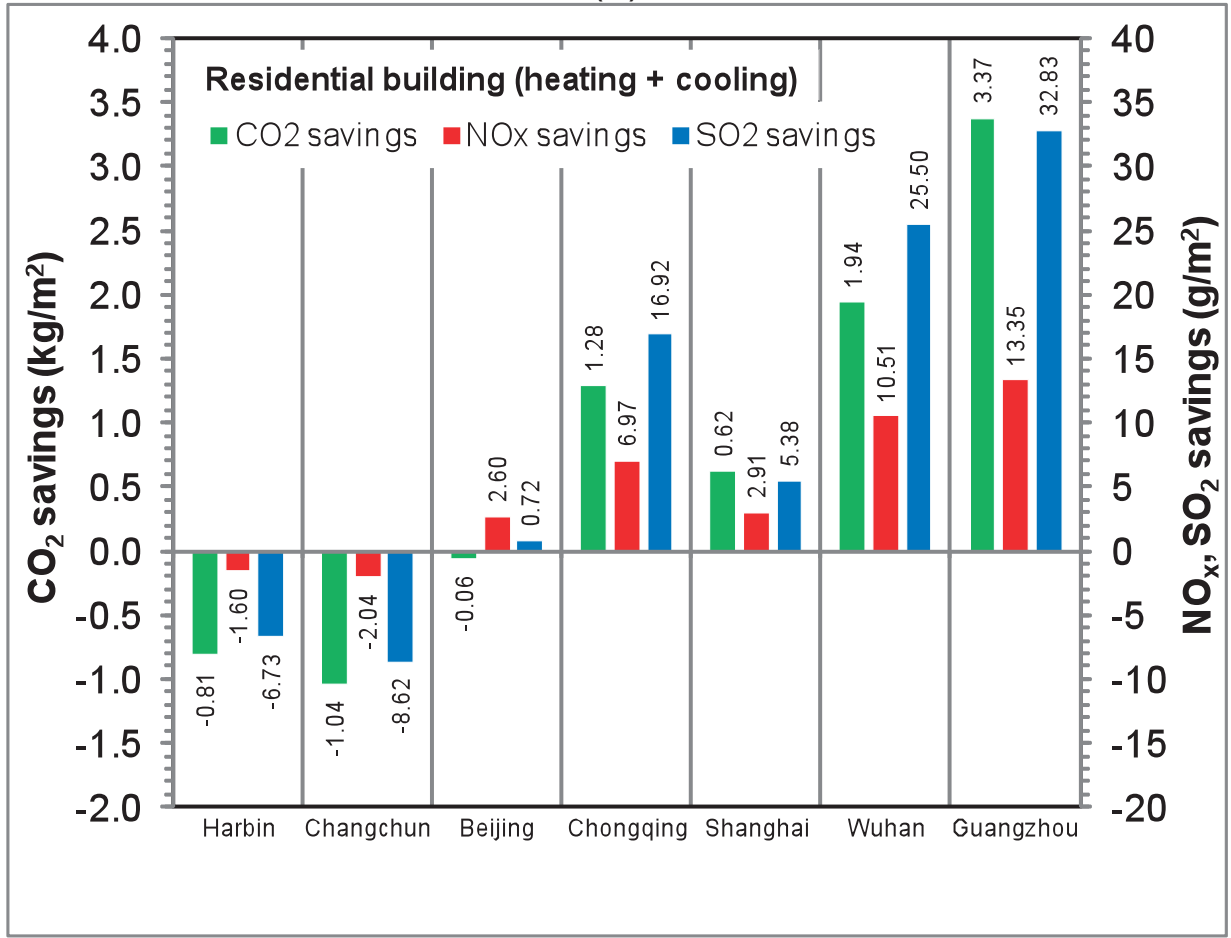

(b)

Figure 17. Annual $\mathrm{CO}_{2}, \mathrm{NO}_{\mathrm{x}}$, and $\mathrm{SO}_{2}$ emission savings per unit $\mathrm{CRA}$ for (a) the office prototype and (b) the residential prototype, upon increasing roof albedo to 0.6 from 0.2 . 


\section{Do not use graphics embedded in this document}

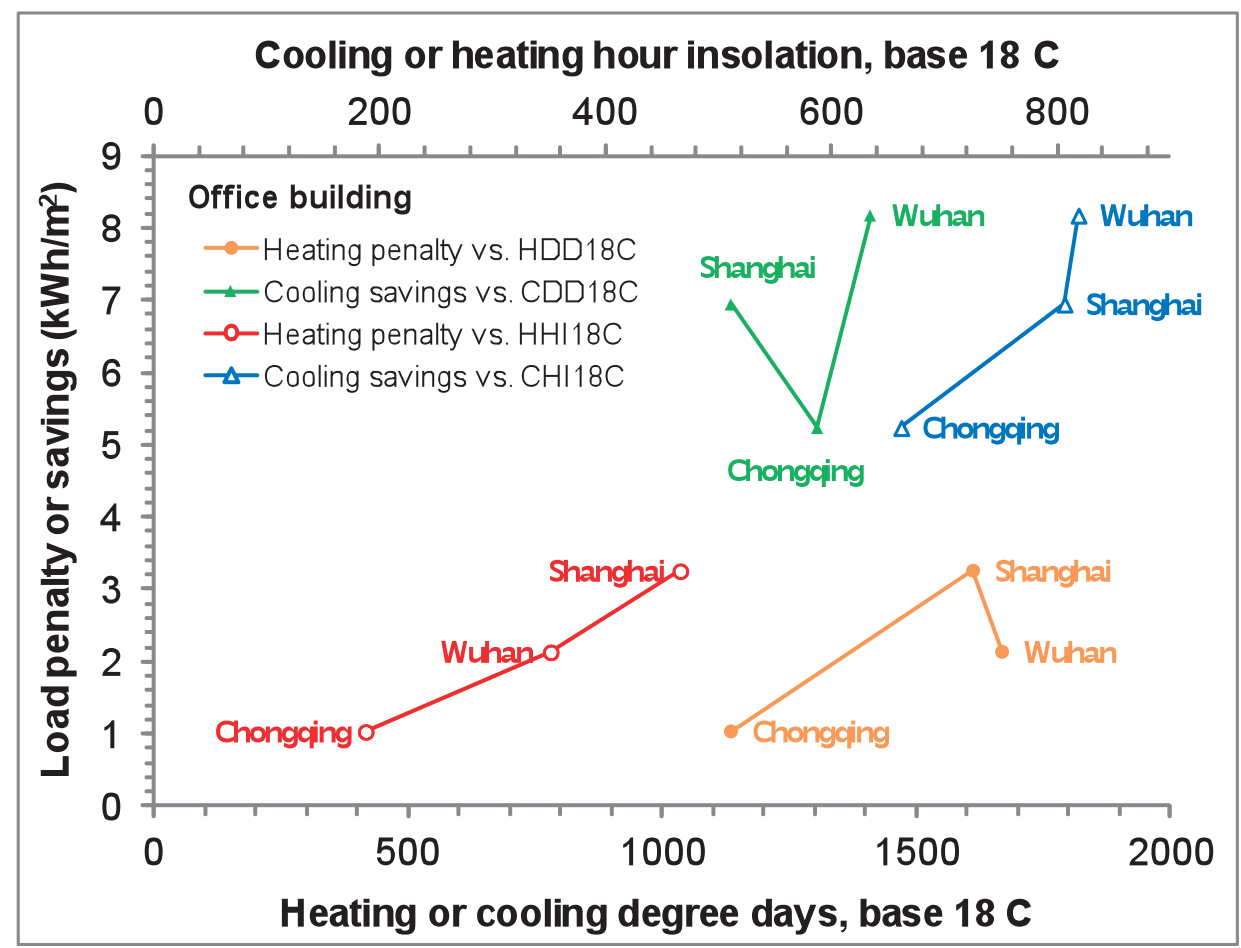

Figure 19. Annual heating and cooling load penalties and savings vary monotonically with heating and cooling hour insolation, but not with heating and cooling degree days.

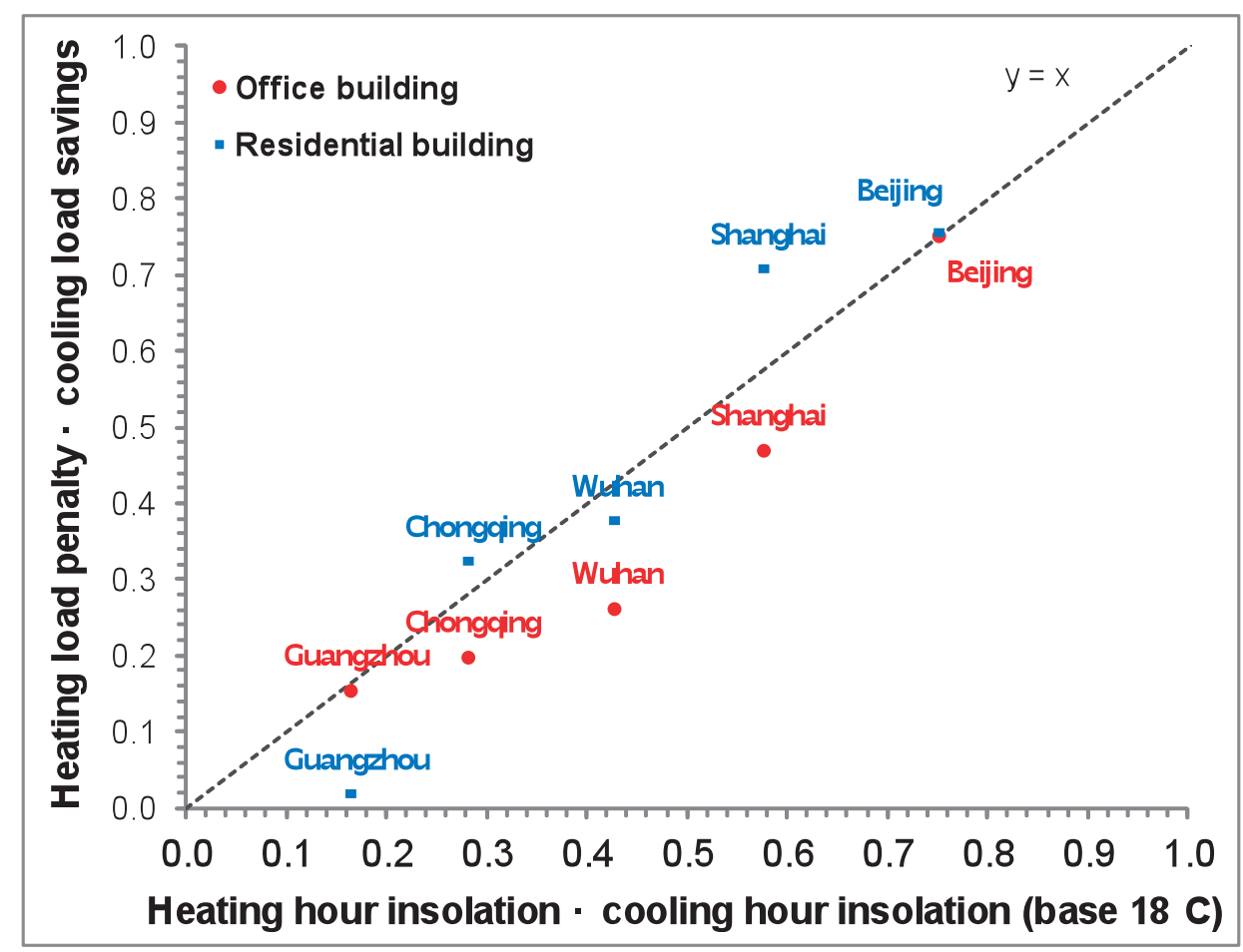

Figure 21. Ratio of annual heating load penalty to annual cooling load savings is approximately equal to the ratio of heating-hour insolation to cooling-hour insolation. 


\section{Do not use graphics embedded in this document}

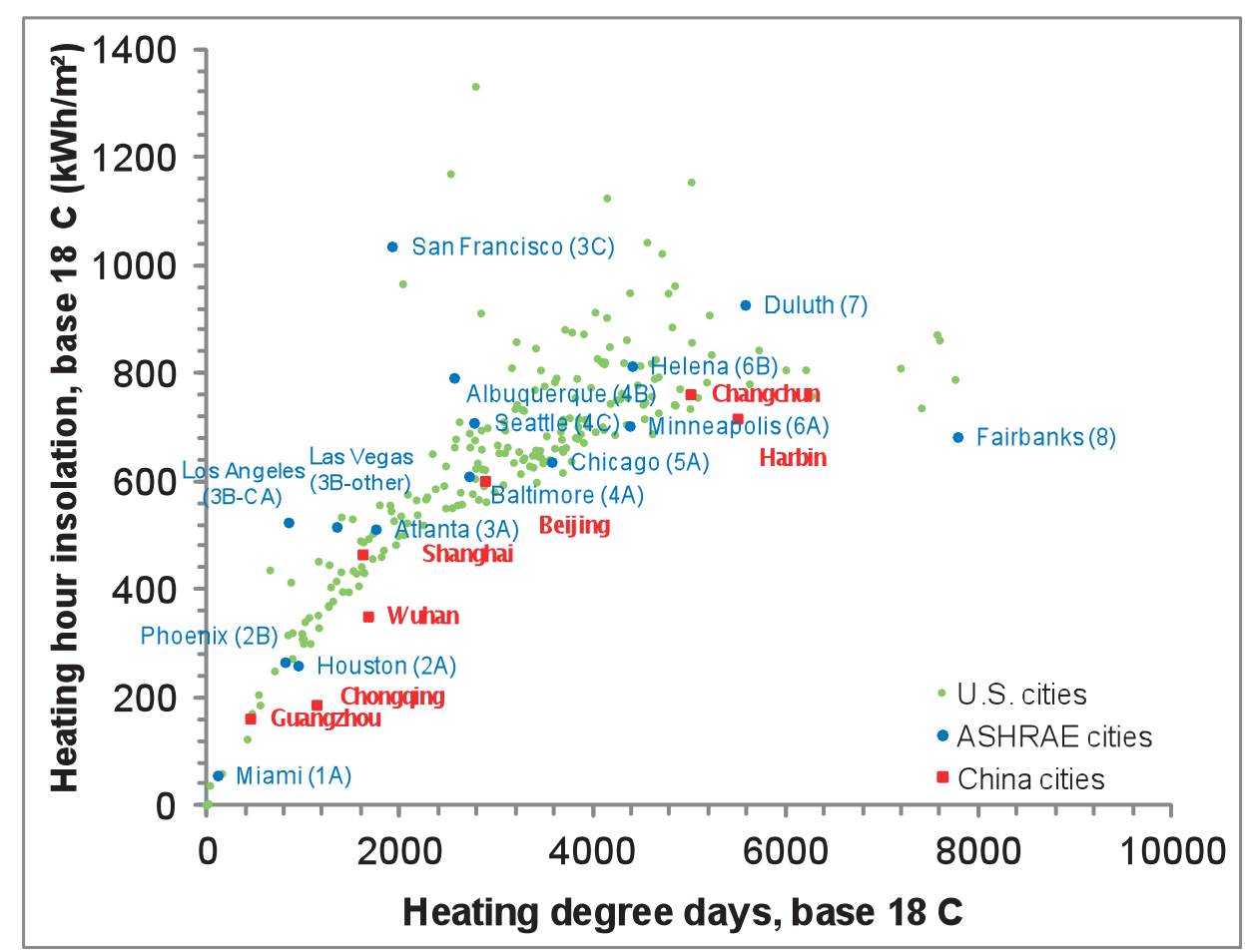

(a)

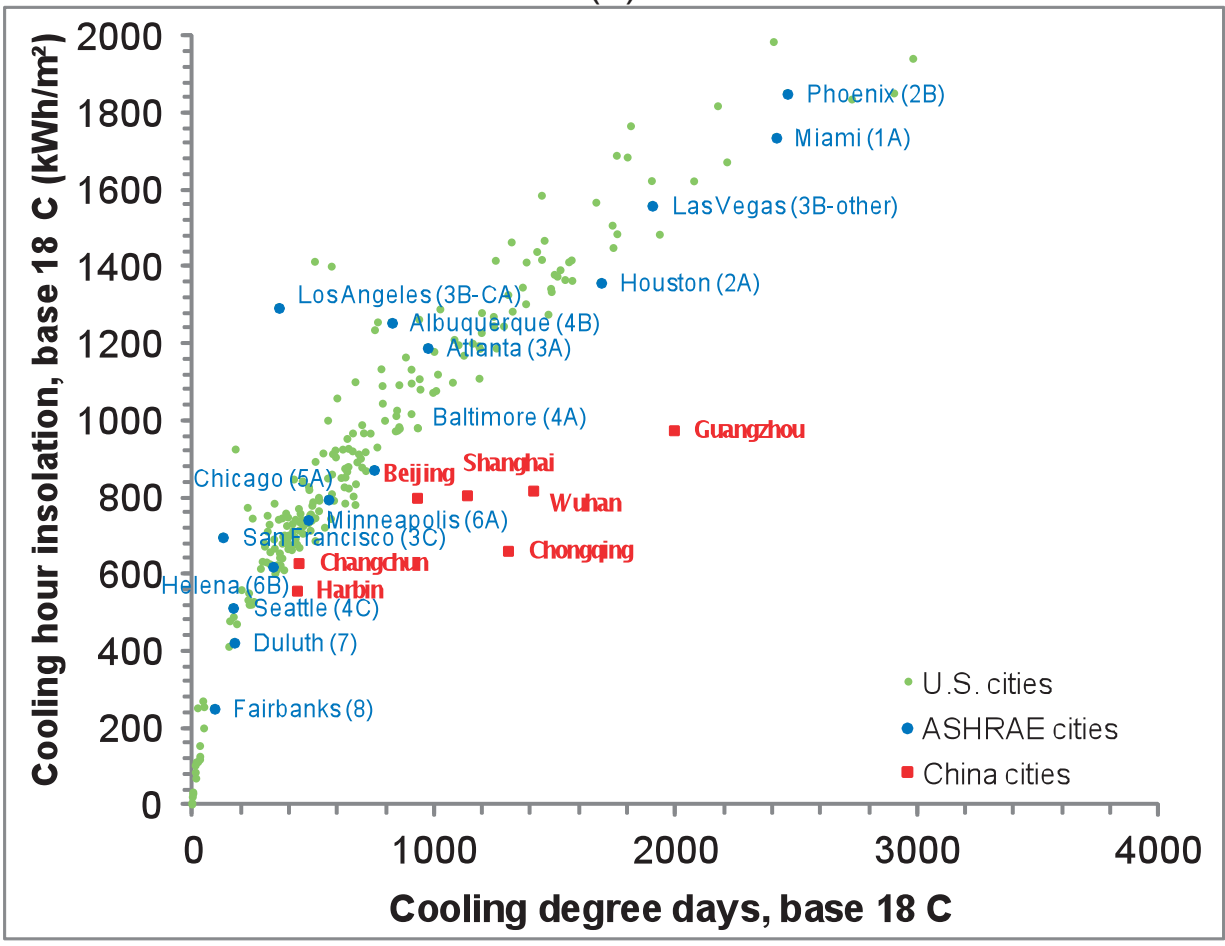

(b)

Figure 23. (a) For equal HDD18C, Chinese and U.S. cities receive comparable heating hour insolation (HHI18C); while (b) for equal CDD18C, Chinese cities receive less cooling hour insolation (CHI18C) than US cities. 
Do not use graphics embedded in this document

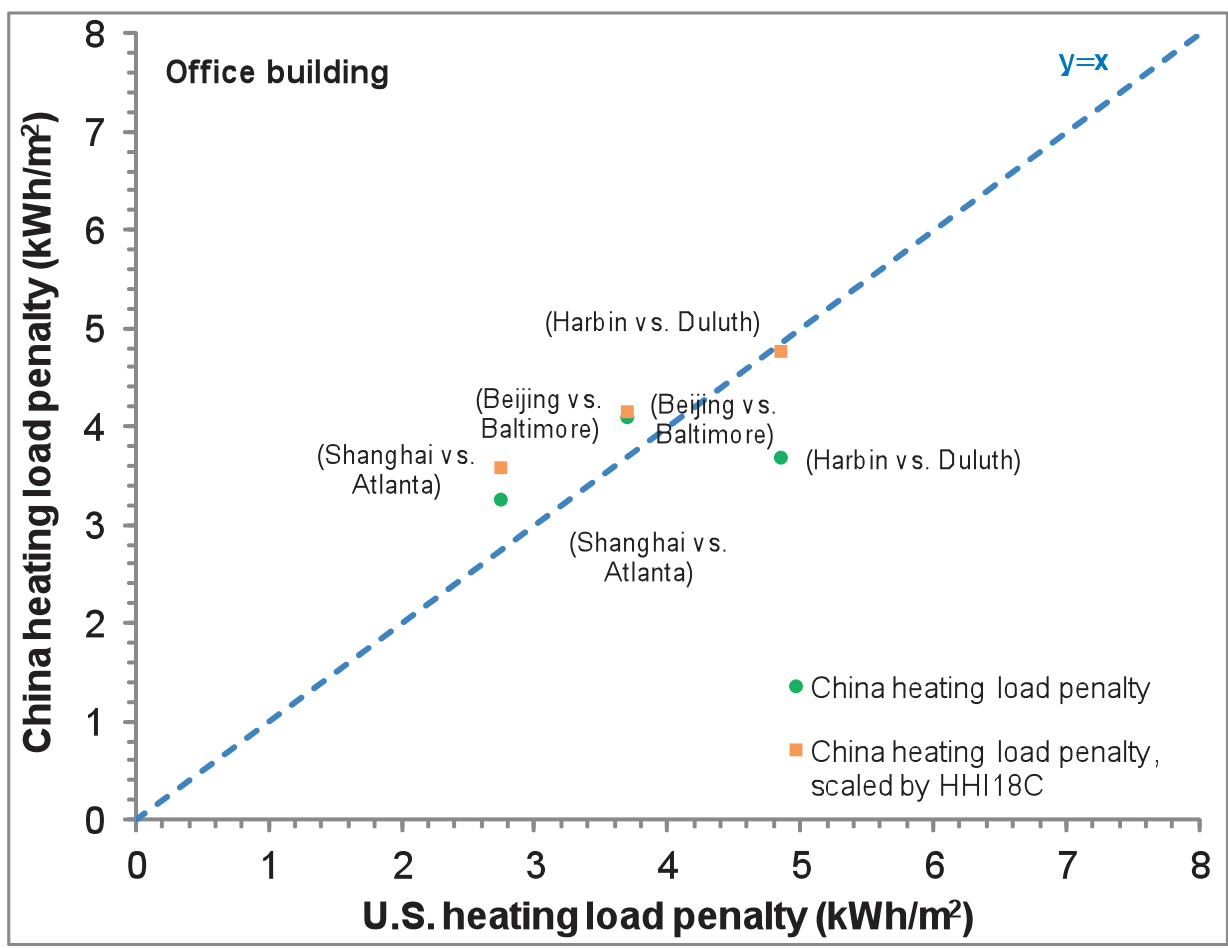

(a)

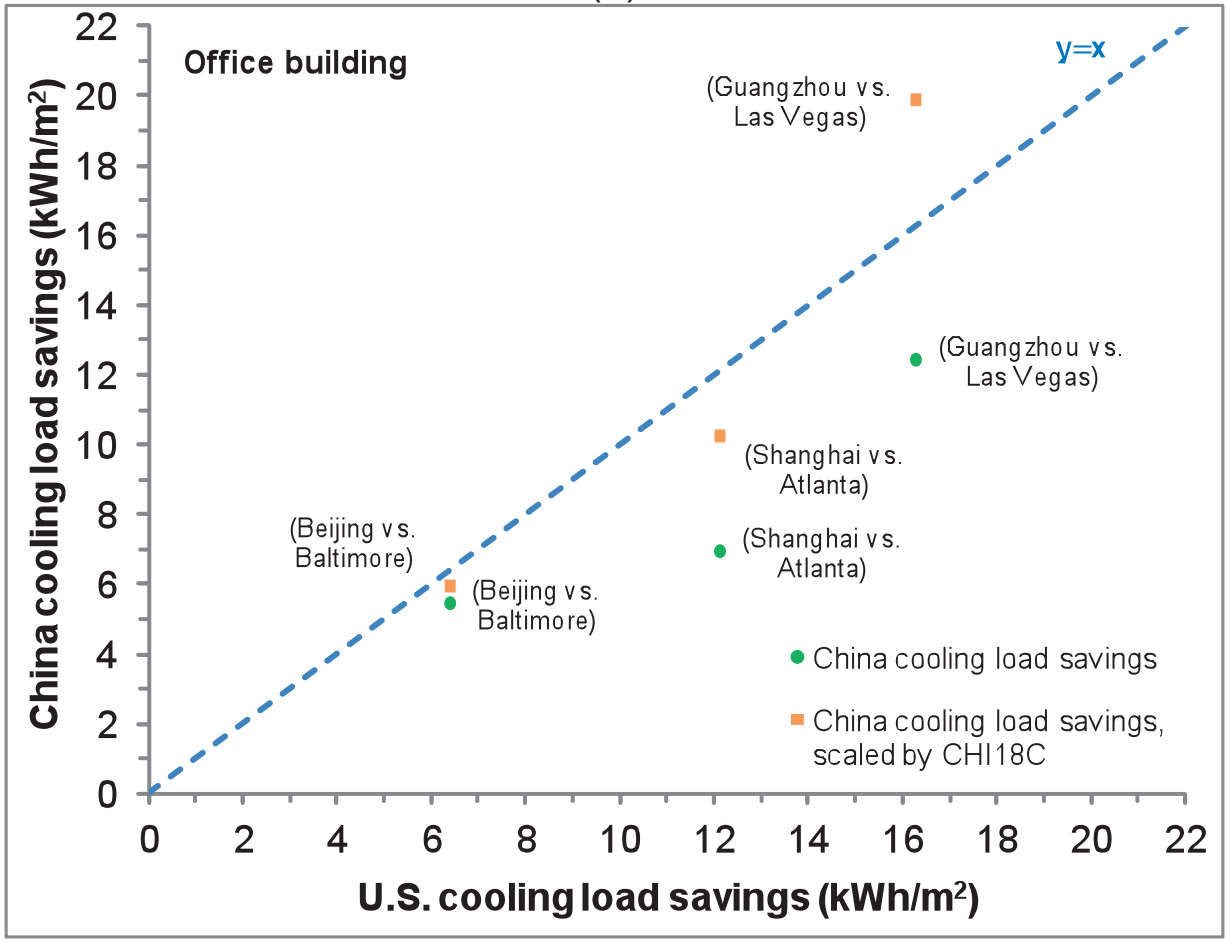

(b)

Figure 25. Comparison of (a) annual heating load penalties and (b) annual cooling load savings in Chinese office buildings to those in the U.S. 


\section{Do not use graphics embedded in this document}

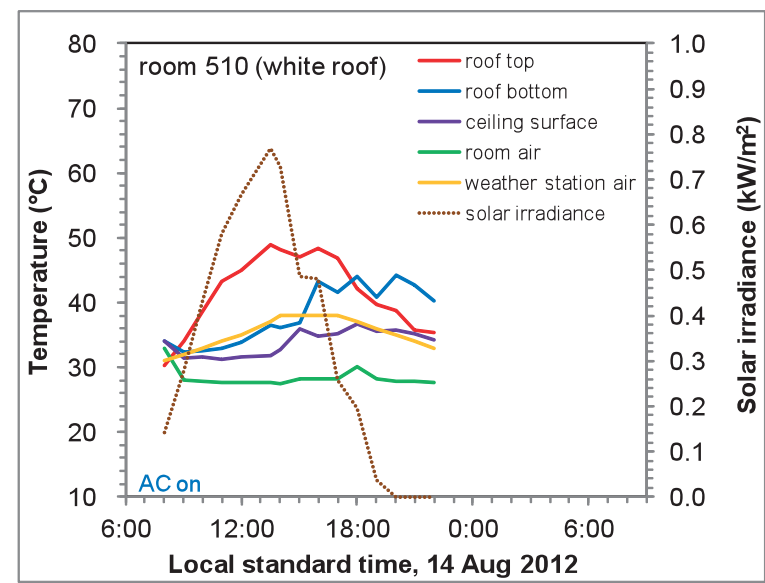

(a)

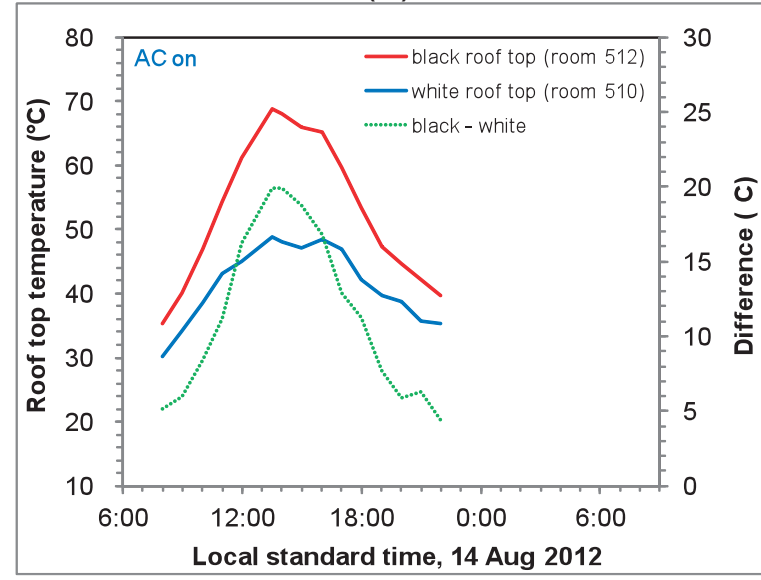

(c)

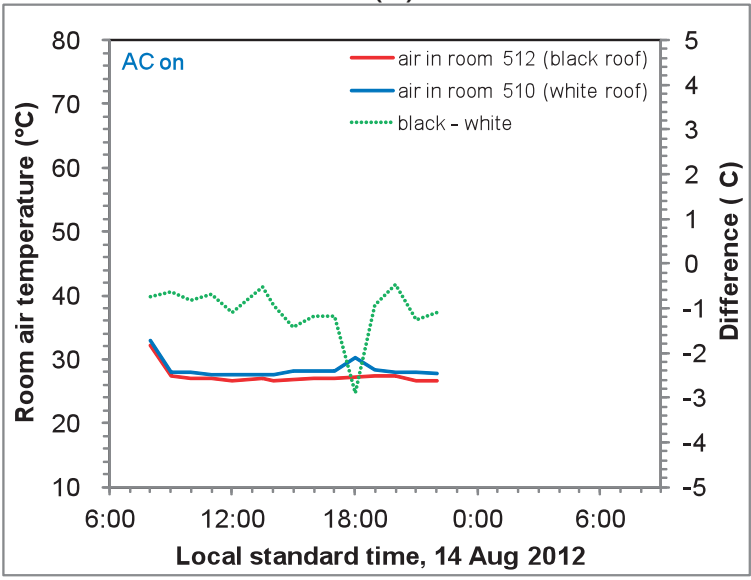

(e)

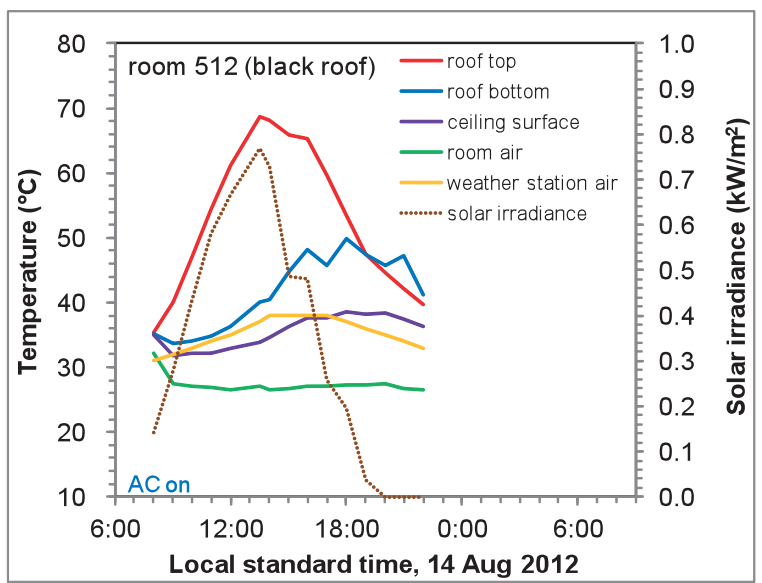

(b)

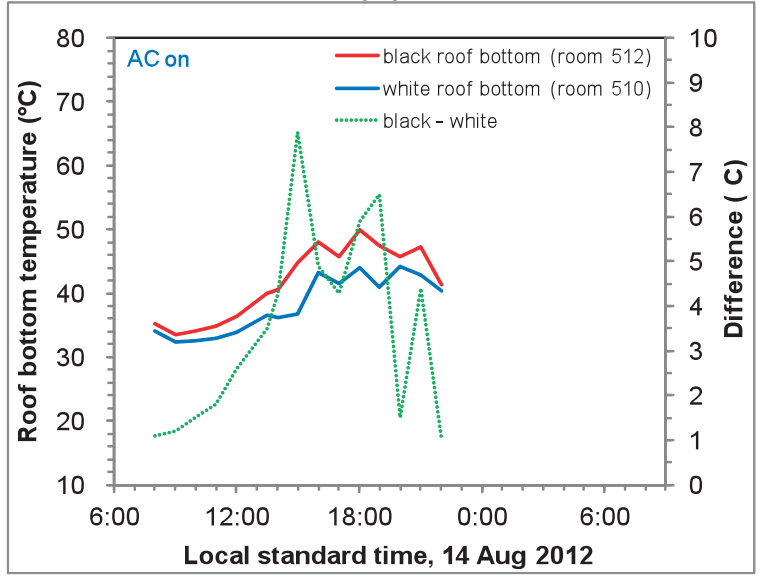

(d)

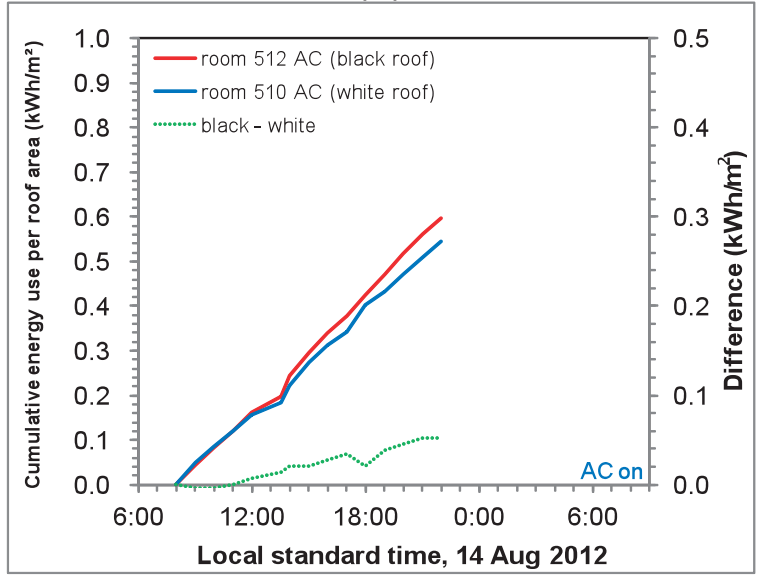

(f)

Figure 27. Measurements made on 14 Aug 2012 in rooms 510 (white roof) and 512 (black roof) of office building at Chongqing University, including (a) white-roof room temperatures; (b) black-roof room temperatures; (c) roof top temperatures; (d) roof bottom temperatures; (e) room air temperatures; and (f) daily cumulative cooling energy uses. Each room was air conditioned from 08:00 to 22:00 LST. 


\section{Do not use graphics embedded in this document}

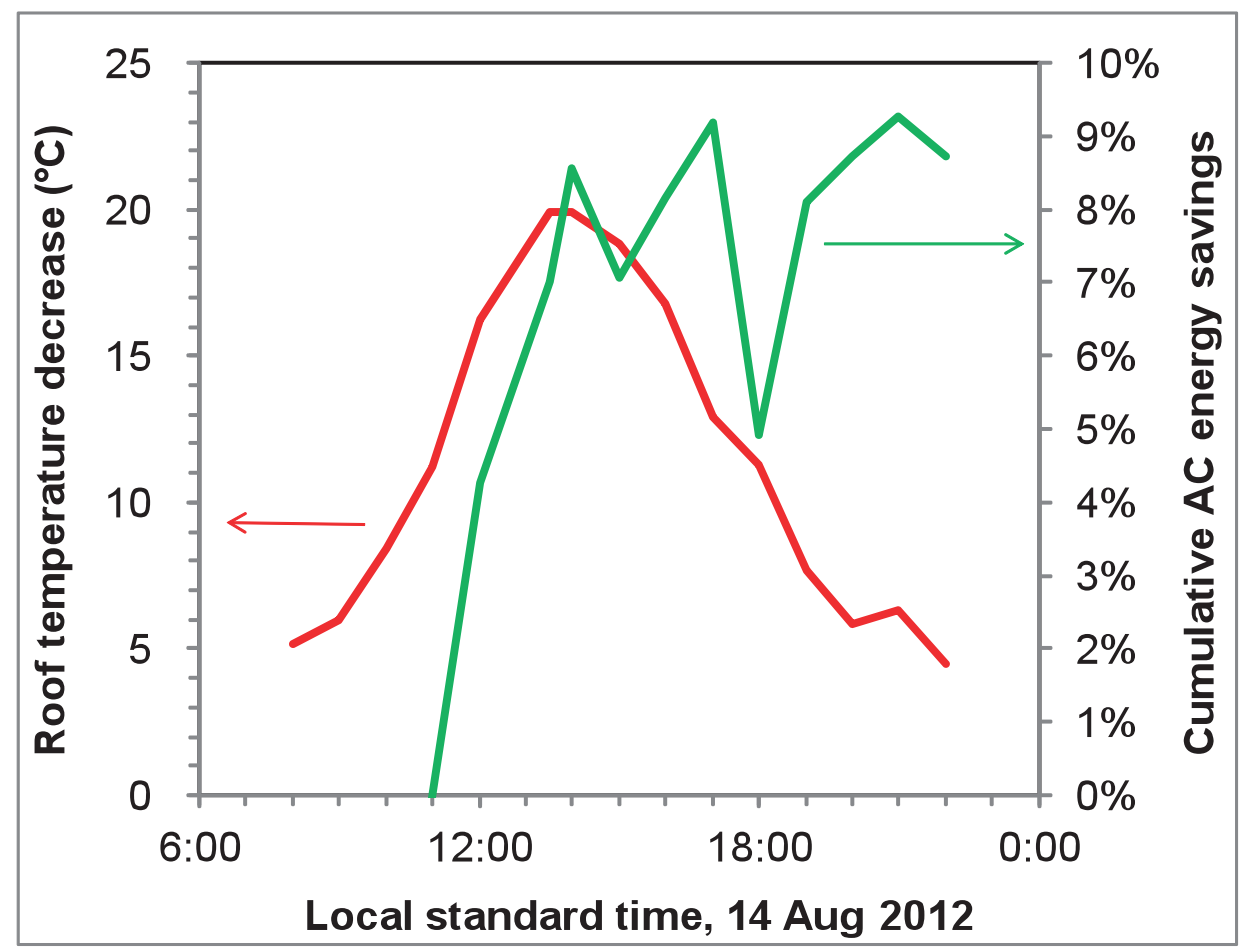

Figure 29. On 14 Aug 2012, the white roof top over room 510 was up to $20{ }^{\circ} \mathrm{C}$ cooler than the black roof top over room 512, and the air conditioner in room 510 consumed about $9 \%$ less electricity than that in room 512 . 


\section{Do not use graphics embedded in this document}

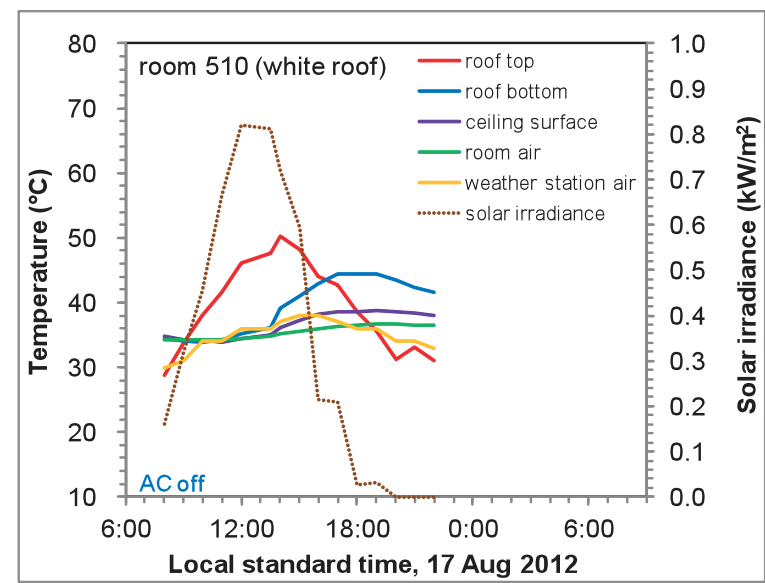

(a)

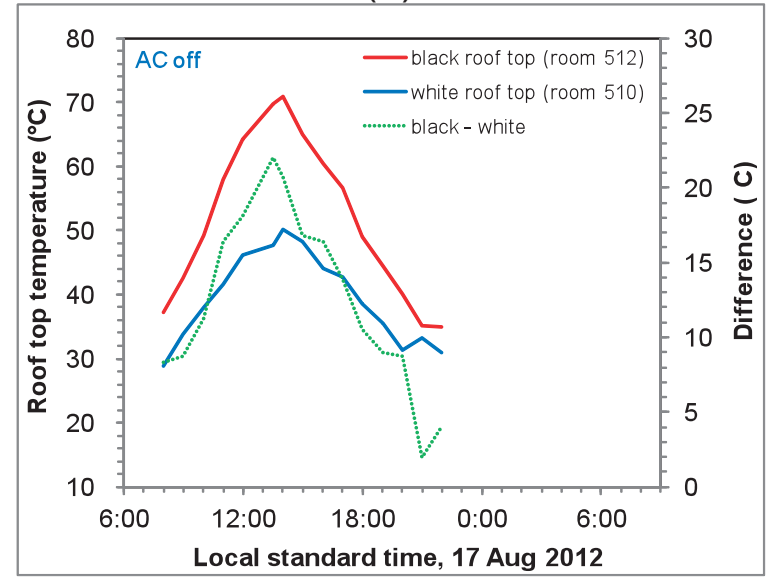

(c)

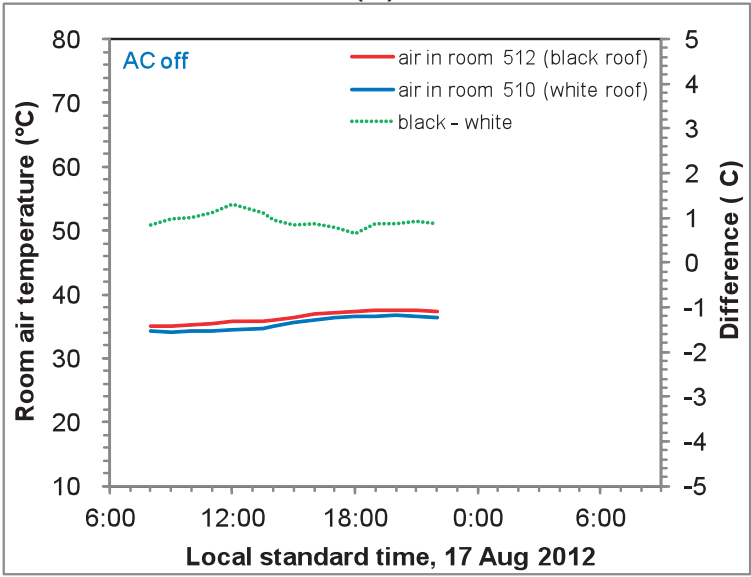

(e)

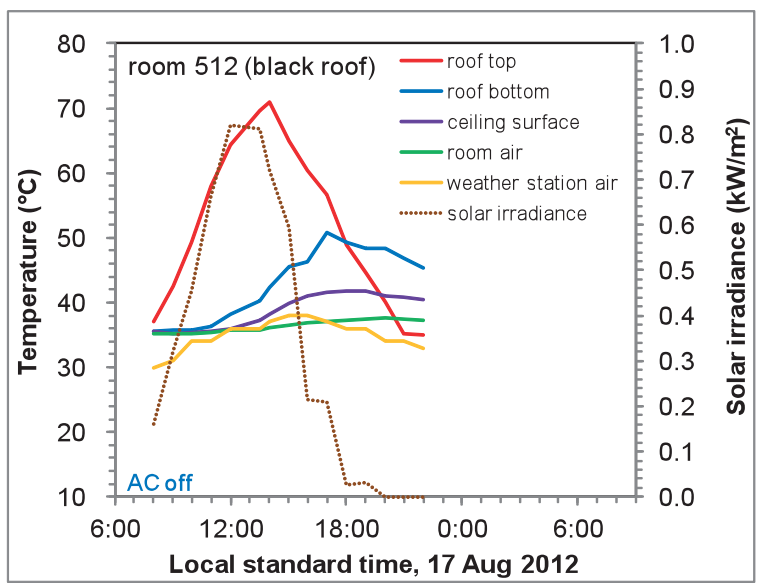

(b)

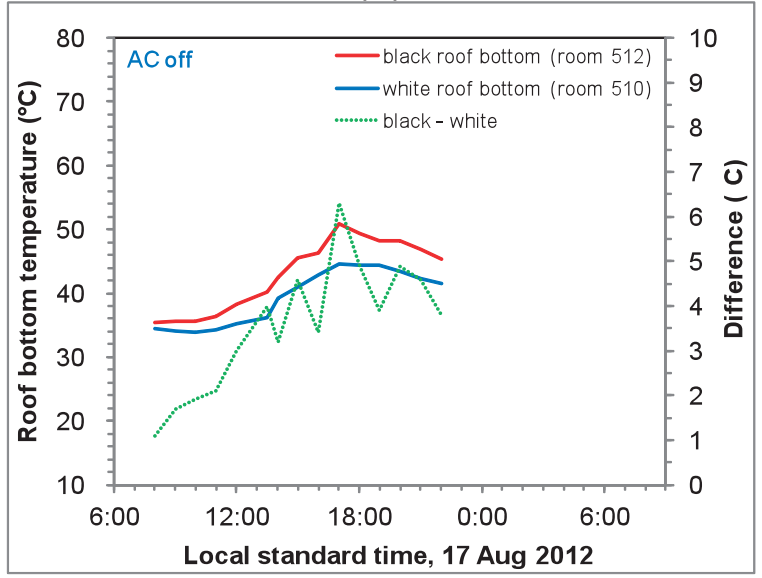

(d)

Figure 31. Measurements made on 17 Aug 2012 in rooms 510 (white roof) and 512 (black roof) of office building at Chongqing University, including including (a) white-roof room temperatures; (b) black-roof room temperatures; (c) roof top temperatures; (d) roof bottom temperatures; and (e) room air temperatures. Neither room was air conditioned. 


\section{Do not use graphics embedded in this document}

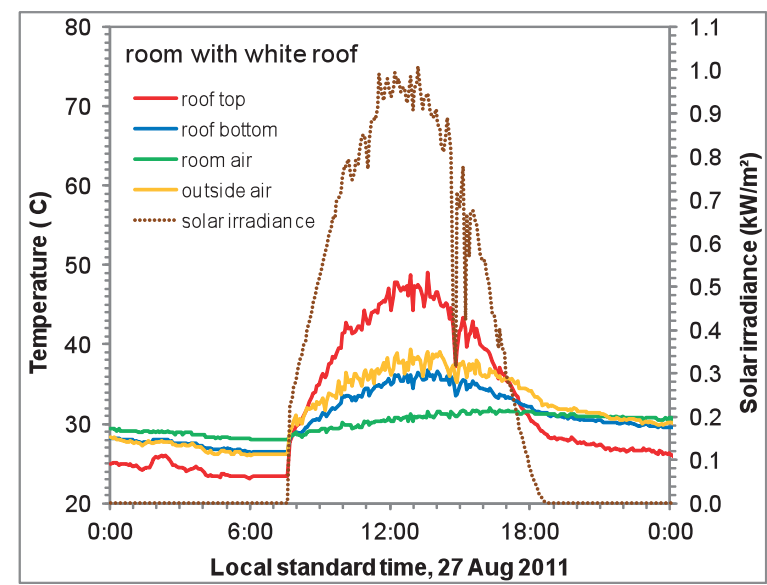

(a)

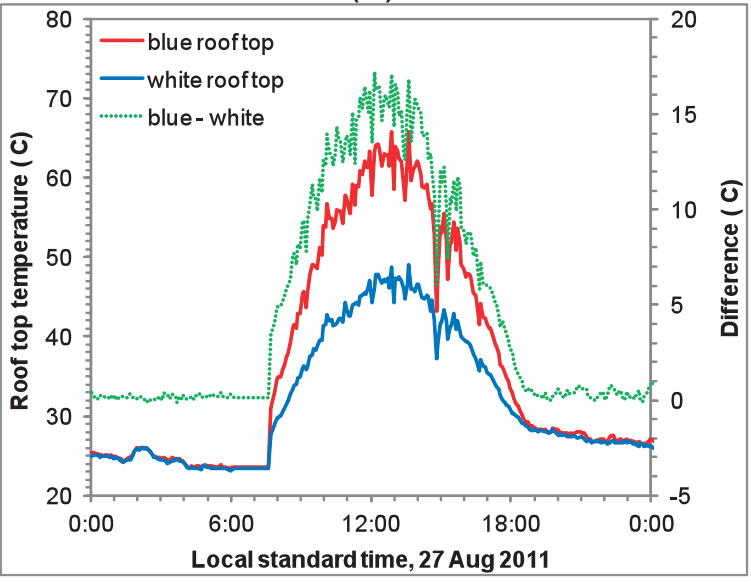

(c)

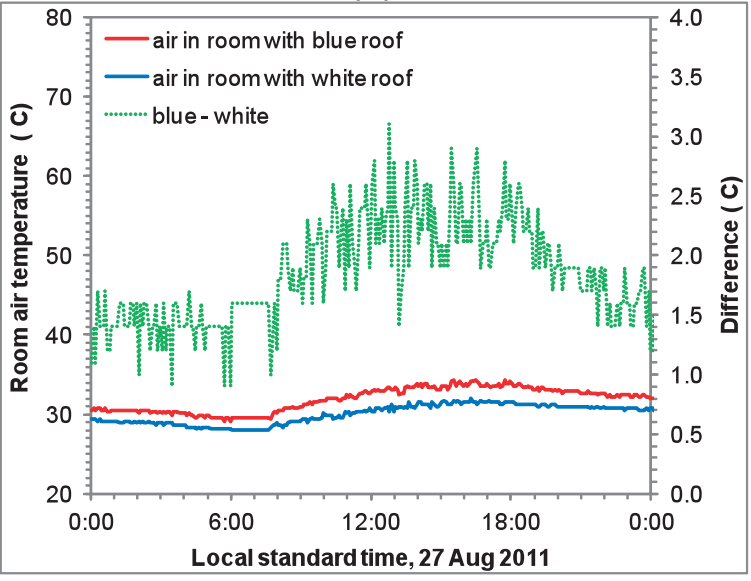

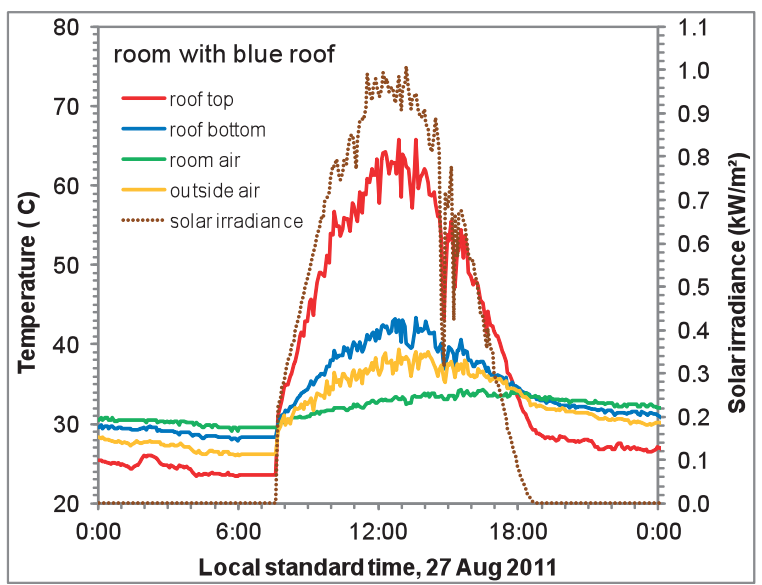

(b)

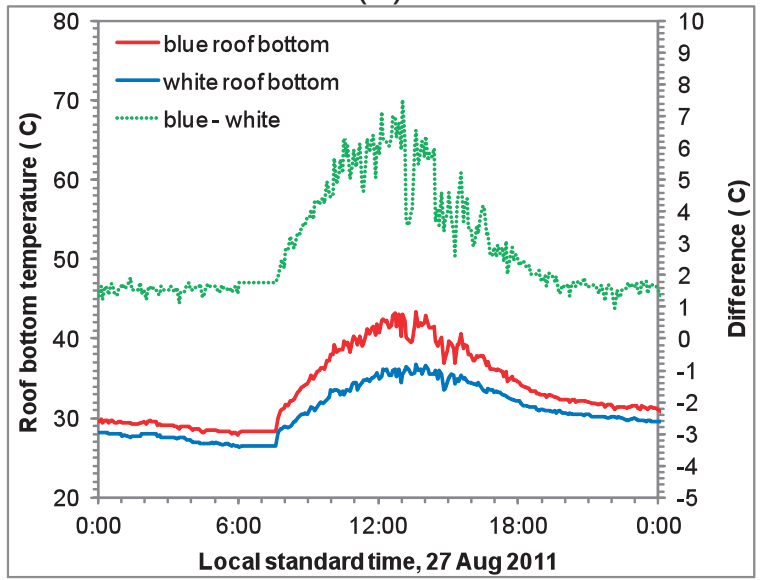

(d)

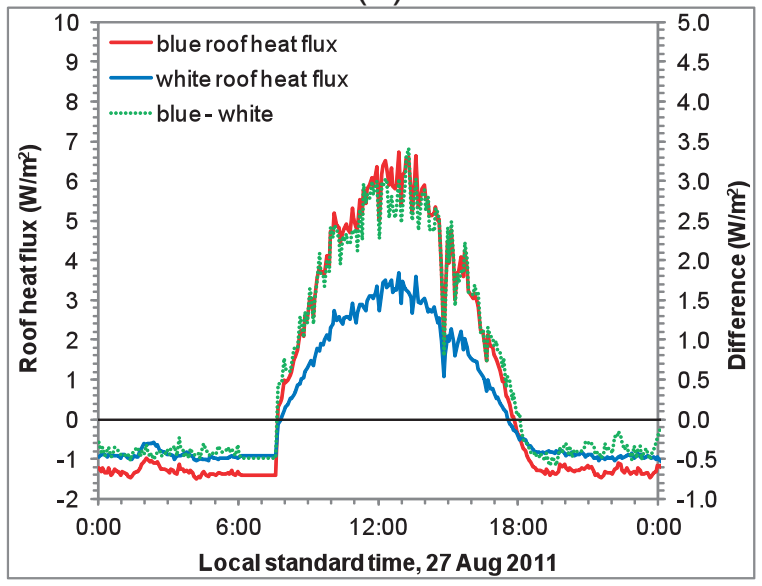

Figure 33. Measurements made 27 Aug 2011 at the naturally ventilated factory in Foshan, including (a) white-roof room temperatures; (b) blue-roof room temperatures; (c) roof top temperatures; (d) roof bottom temperatures; (e) room air temperatures; and (f) roof heat fluxes. 
Do not use graphics embedded in this document 
Do not use graphics embedded in this document 
A Prototype geometry

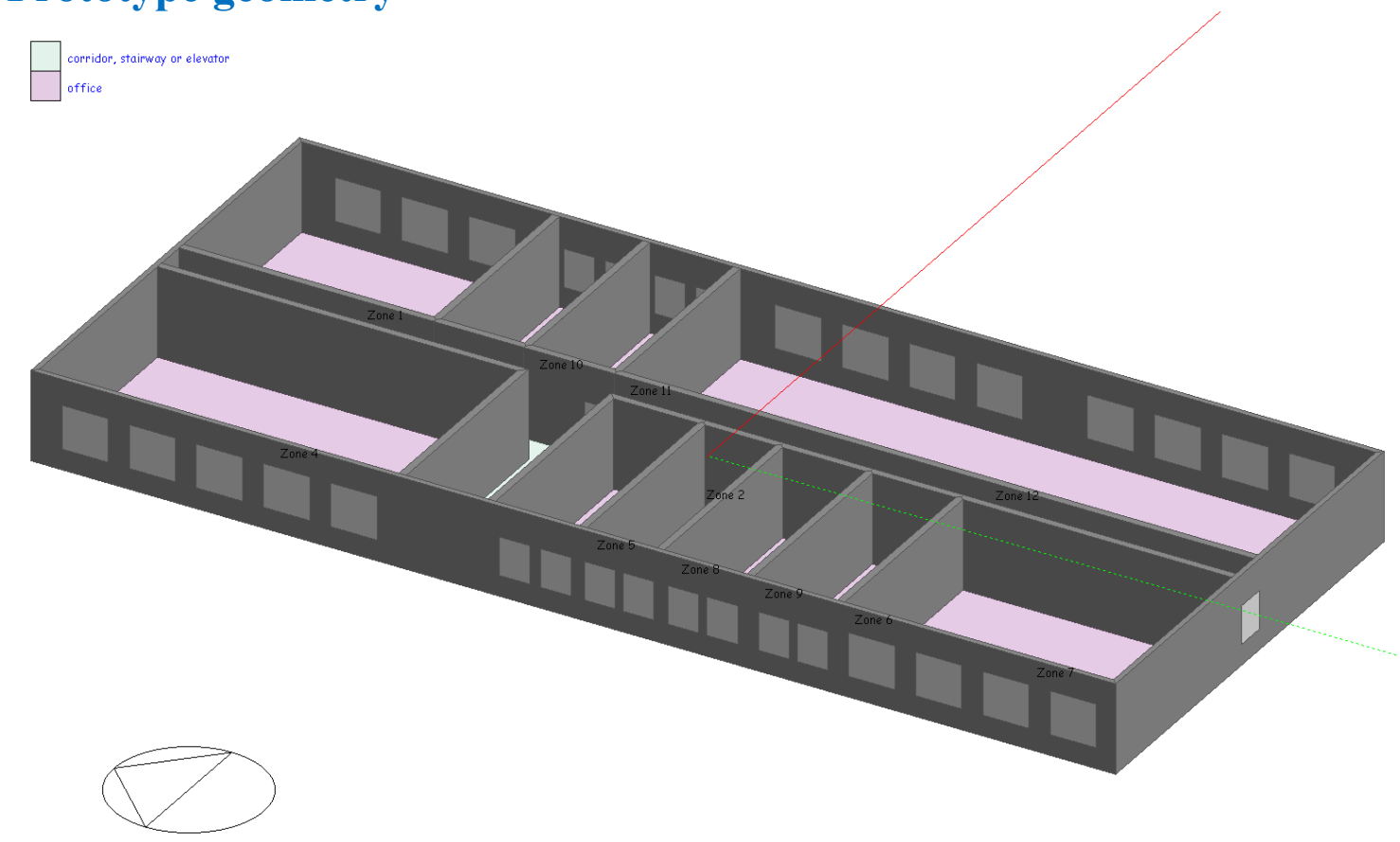

(a)
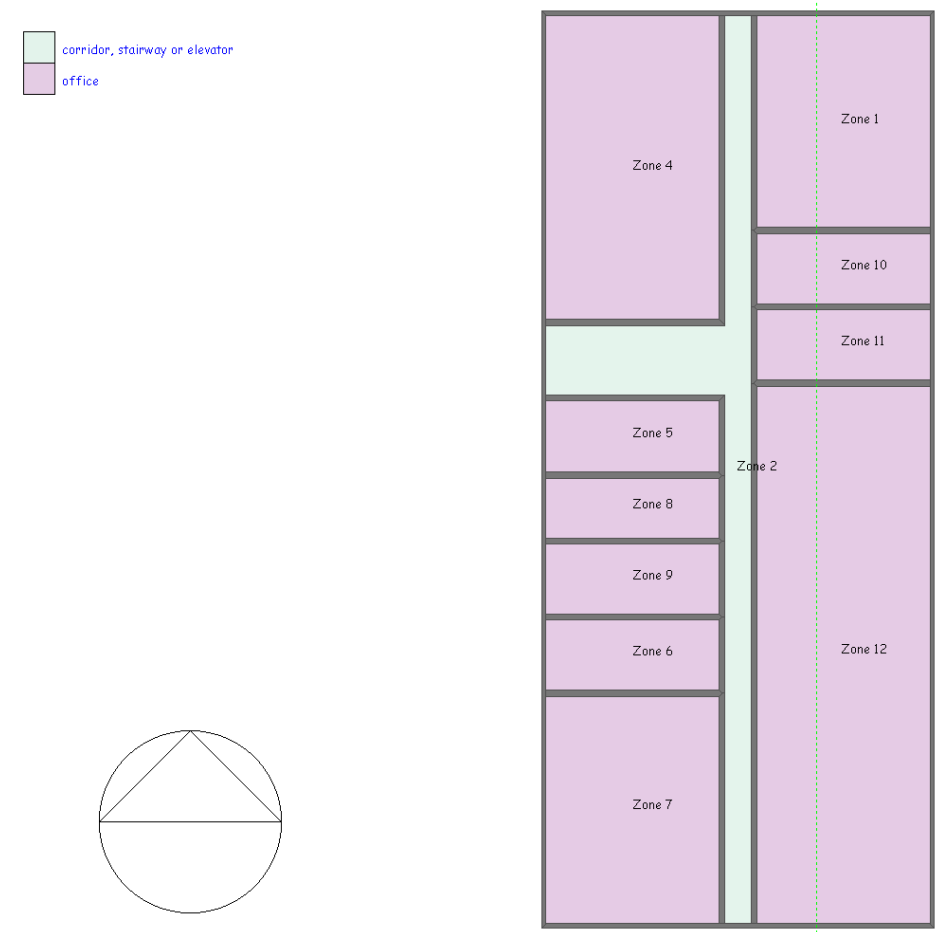

(b)

Figure A-1. (a) Axonometric projection and (b) plan of the top floor of the office building. 


\section{Do not use graphics embedded in this document}

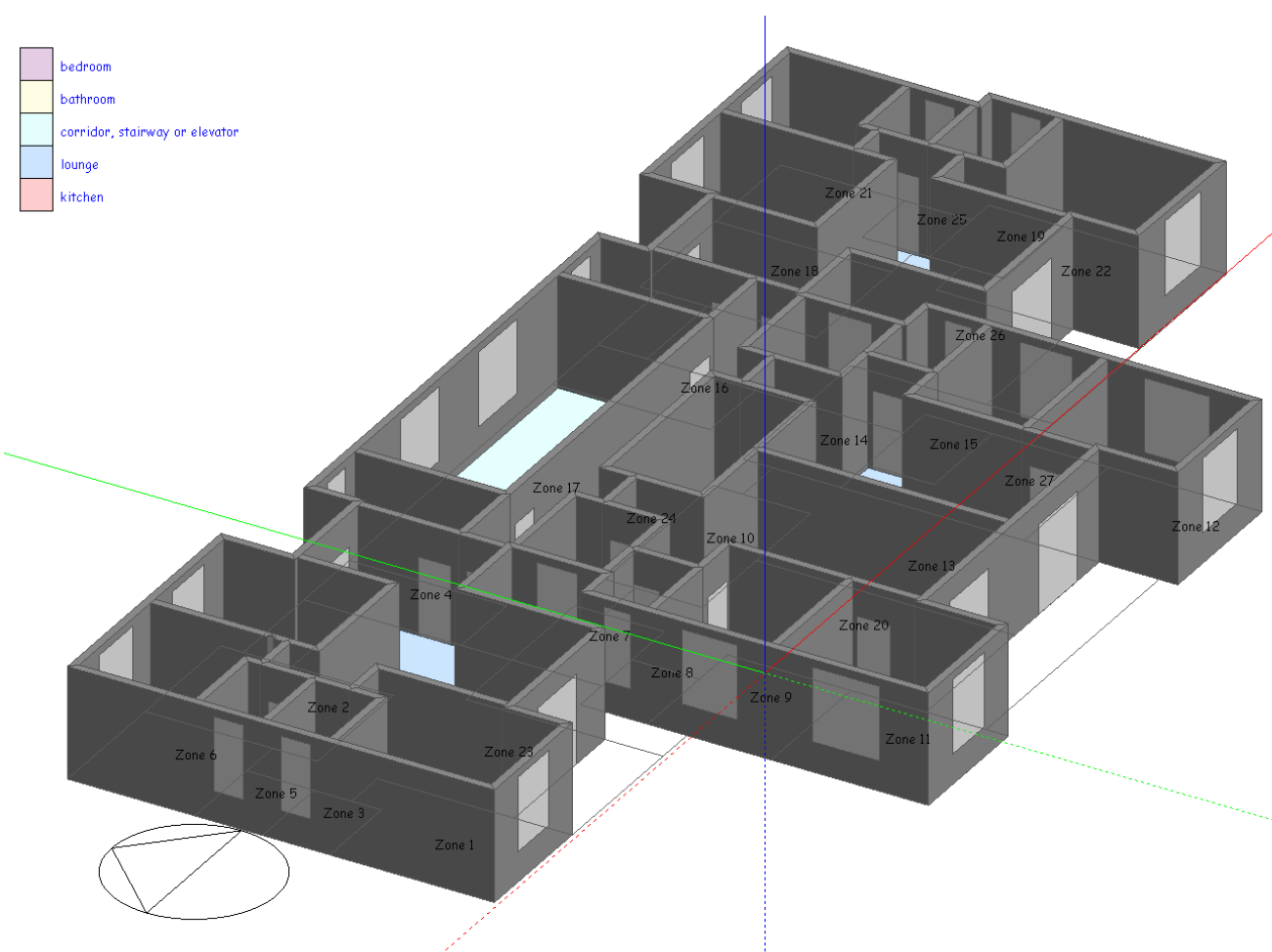

(a)

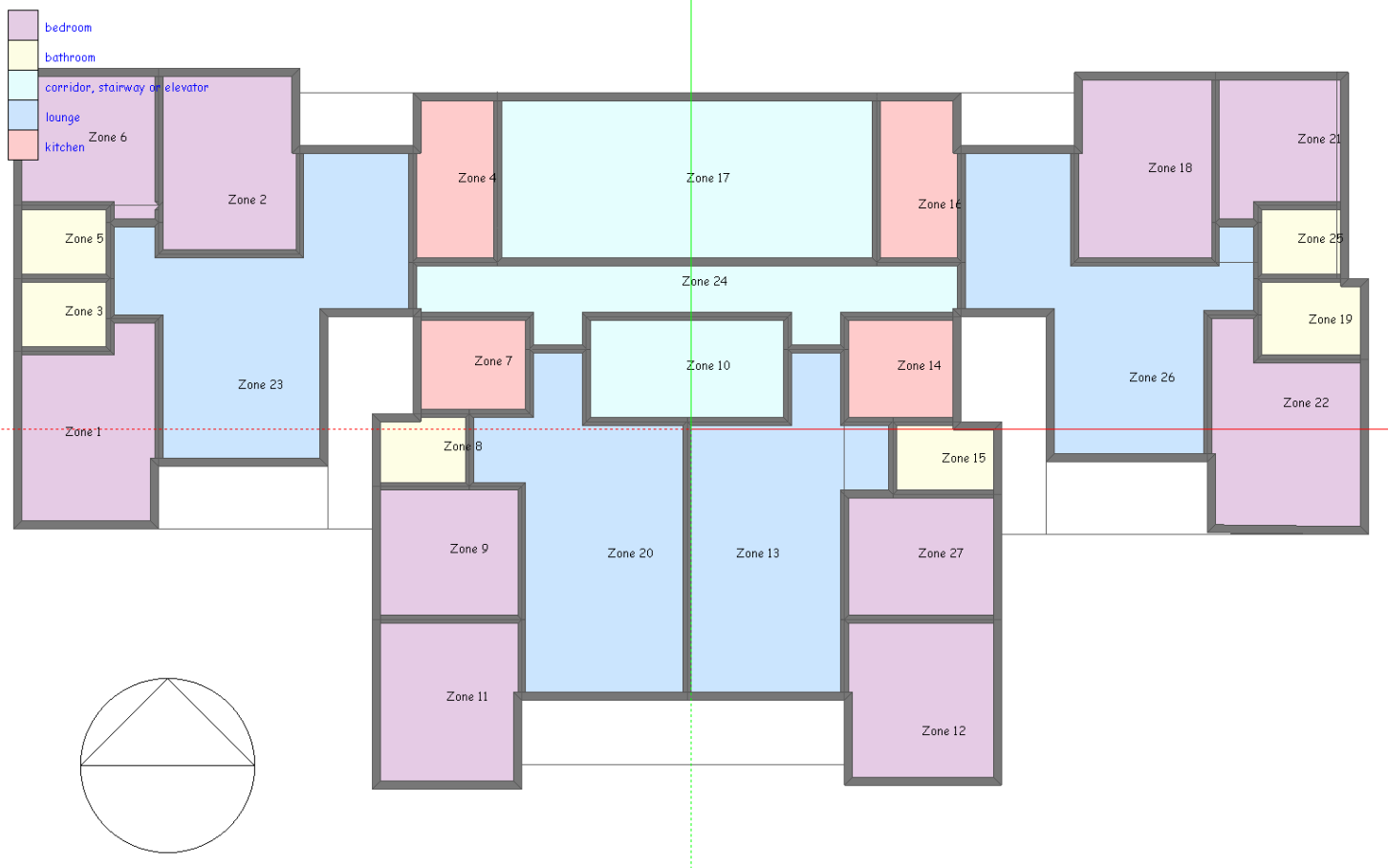

(b)

Figure A-2. (a) Axonometric projection and (b) plan of the top floor of the residential building. 


\section{Do not use graphics embedded in this document}

\section{B Geography and climate}

Table B-1. Geography and climate of simulated Chinese cities.

\begin{tabular}{|c|c|c|c|c|c|c|c|c|c|c|}
\hline City & $\begin{array}{l}\text { Latitude } \\
\left({ }^{\circ} \mathrm{N}\right)\end{array}$ & $\begin{array}{l}\text { Longitude } \\
\left({ }^{\circ} \mathrm{E}\right)\end{array}$ & \begin{tabular}{|l} 
Altitude \\
(m)
\end{tabular} & \begin{tabular}{|l} 
Climate \\
zone
\end{tabular} & $\begin{array}{l}\text { Annual mean } \\
\text { global } \\
\text { horizontal } \\
\text { solar } \\
\text { irradiance } \\
{\left[\mathrm{W} \mathrm{m}^{-2}\right]^{\mathrm{a}}}\end{array}$ & \begin{tabular}{|l} 
Annual \\
heating \\
degree \\
days \\
(HDD18C) \\
\end{tabular} & \begin{tabular}{|l|} 
Annual \\
cooling \\
degree \\
days \\
(CDD18C) \\
a
\end{tabular} & $\begin{array}{l}\text { Annual } \\
\text { cooling } \\
\text { degree } \\
\text { days } \\
\text { (CDD26C) }\end{array}$ & $\begin{array}{l}\text { Annual } \\
\text { heating } \\
\text { hour } \\
\text { insolation, } \\
\text { base } 18^{\circ} \mathrm{C} \\
{\left[\mathrm{kWh} / \mathrm{m}^{2}\right]}\end{array}$ & 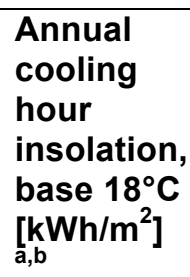 \\
\hline Harbin & 45.75 & 126.77 & 142 & $\begin{array}{l}\text { Severe } \\
\text { cold A }\end{array}$ & 145 & 5497 & 431 & 36 & 713 & 558 \\
\hline Changchun & 43.90 & 125.22 & 237 & $\begin{array}{l}\text { Severe } \\
\text { cold B }\end{array}$ & 159 & 5010 & 438 & 30 & 755 & 629 \\
\hline Beijing & 39.93 & 116.28 & 31 & Cold B & 160 & 2882 & 928 & 154 & 597 & 799 \\
\hline Chongqing & 29.58 & 106.47 & 259 & \begin{tabular}{|l|} 
Hot \\
summer/ \\
cold \\
winter \\
\end{tabular} & 97 & 1135 & 1305 & 238 & 185 & 661 \\
\hline Wuhan & 30.62 & 114.13 & 23 & $\begin{array}{l}\text { Hot } \\
\text { summer/ } \\
\text { cold } \\
\text { winter }\end{array}$ & 133 & 1669 & 1409 & 320 & 349 & 818 \\
\hline Shanghai & 31.40 & 121.45 & 6 & $\begin{array}{l}\text { Hot } \\
\text { summer/ } \\
\text { cold } \\
\text { winter }\end{array}$ & 145 & 1612 & 1135 & 159 & 461 & 806 \\
\hline Guangzhou & 23.17 & 113.33 & 41 & $\begin{array}{l}\text { Hot } \\
\text { summer/ } \\
\text { warm } \\
\text { winter }\end{array}$ & 130 & 447 & 1991 & 356 & 159 & 975 \\
\hline
\end{tabular}

${ }^{a}$ Computed from EnergyPlus weather files CHN_Heilongjiang.Harbin.509530_CSWD (Harbin), CHN_Jilin.Changchun.541610_CSWD (Changchun), CHN_Beijing.Beijing.545110_CSW̄D (Beijing), CHN_Chongqing.Chongqing.Shapingba.575160_CSWD (Chongqing), CHN_Hubei.Wuhan.574940_CSWD (Wuhan), CHN_Shanghai.Shanghai.583620_CSWD (Shanghai), and CHN_Guangdong.Guangzhou.592870_CSWD (Guangzhou). 


\section{Do not use graphics embedded in this document}

${ }^{\mathrm{b}}$ Heating hour insolation, base $18^{\circ} \mathrm{C}(\mathrm{HH} 18 \mathrm{C})$ is the sum of all insolation received when the outside air dry-bulb temperature does not exceed $18^{\circ} \mathrm{C}$. Cooling hour insolation, base $18^{\circ} \mathrm{C}(\mathrm{CHI} 18 \mathrm{C})$ is the sum of all insolation received when the outside air dry-bulb temperature exceeds $18^{\circ} \mathrm{C}$. 


\section{Roof and wall construction}

Roof and wall construction details are derived from Hongye, a database of the envelope and material properties of Chinese buildings (Hongye Technology 2012).

Table C-1. Roof construction (outside to inside) simulated in each Chinese city.

\begin{tabular}{|c|c|c|}
\hline City & Public building & Residential building \\
\hline Harbin & $\begin{array}{l}250 \mathrm{~mm} \text { cement mortar }+50 \mathrm{~mm} \text { XPS }+ \\
25 \mathrm{~mm} \text { cement mortar }+30 \mathrm{~mm} \text { cement slag } \\
+120 \mathrm{~mm} \text { reinforced concrete }+25 \mathrm{~mm} \\
\text { cement mortar }\end{array}$ & $\begin{array}{l}1 \mathrm{~mm} \text { waterproof membrane }+20 \mathrm{~mm} \text { dry } \\
\text { boiler slag }+150 \mathrm{~mm} \text { XPS board }+120 \mathrm{~mm} \\
\text { hollow-center concrete block }\end{array}$ \\
\hline Changchun & $\begin{array}{l}1 \mathrm{~mm} \text { waterproofing membrane }+30 \mathrm{~mm} \\
\text { C15 concrete }+120 \mathrm{~mm} \text { ceramsite concrete } \\
+50 \mathrm{~mm} \text { slag concrete polystyrene board }+ \\
46 \mathrm{~mm} \text { clinker }+100 \mathrm{~mm} \text { reinforced concrete } \\
+20 \mathrm{~mm} \text { lime cement mortar }\end{array}$ & $\begin{array}{l}1 \mathrm{~mm} \text { waterproof membrane }+20 \mathrm{~mm} \text { dry } \\
\text { boiler slag }+120 \mathrm{~mm} \text { EPS board }+120 \mathrm{~mm} \\
\text { hollow-center concrete block }\end{array}$ \\
\hline Beijing & $\begin{array}{l}20 \mathrm{~mm} \text { pebble layer }+20 \mathrm{~mm} \text { protective film } \\
+32 \mathrm{~mm} \text { polystyrene board }+5 \mathrm{~mm} \\
\text { waterproofing layer }+15 \mathrm{~mm} \text { cement grout + } \\
15 \mathrm{~mm} \text { lightweight aggregate concrete }+ \\
200 \mathrm{~mm} \text { reinforced concrete }\end{array}$ & $\begin{array}{l}10 \mathrm{~mm} \text { waterproof membrane }+30 \mathrm{~mm} \\
\mathrm{C} 15 \text { concrete }+120 \mathrm{~mm} \text { ceramasite } \\
\text { concrete }+50 \mathrm{~mm} \text { expanded polystyrene } \\
\text { panel }+50 \mathrm{~mm} \text { clinker }+100 \mathrm{~mm} \text { reinforced } \\
\text { concrete }+20 \mathrm{~mm} \text { lime cement mortar }\end{array}$ \\
\hline Chongqing & $\begin{array}{l}40 \mathrm{~mm} \text { C20 fine stone concrete }+20 \mathrm{~mm} \\
\text { cement grout }+32 \mathrm{~mm} \text { XPS }+1 \mathrm{~mm} \\
\text { waterproofing membrane }+20 \mathrm{~mm} \text { cement } \\
\text { grout }+1 \mathrm{~mm} \text { polyurethane coating }+20 \mathrm{~mm} \\
\text { cement grout }+110 \mathrm{~mm} \text { reinforced concrete }\end{array}$ & $\begin{array}{l}1 \mathrm{~mm} \text { waterproofing membrane }+20 \mathrm{~mm} \\
\text { cement grout }+128 \mathrm{~mm} \text { aerated concrete } \\
\text { foam }+20 \mathrm{~mm} \text { cement grout }+120 \mathrm{~mm} \\
\text { reinforced concrete }+20 \mathrm{~mm} \text { lime cement } \\
\text { mortar }\end{array}$ \\
\hline Wuhan & Same as Chongqing & Same as Chongqing \\
\hline Shanghai & Same as Chongqing & Same as Chongqing \\
\hline Guangzhou & $\begin{array}{l}40 \mathrm{~mm} \text { gravel cobble concrete }+10 \mathrm{~mm} \text { lime } \\
\text { mortar }+1 \mathrm{~mm} \text { waterproofing membrane }+ \\
20 \mathrm{~mm} \text { cement grout }+8 \mathrm{~mm} \text { Lytag concrete } \\
+26 \mathrm{~mm} \text { Styrofoam }+100 \mathrm{~mm} \text { reinforced } \\
\text { concrete }\end{array}$ & Same as Chongqing \\
\hline
\end{tabular}

Table C-3. Wall construction (outside to inside) simulated in each Chinese city.

\begin{tabular}{|l|l|l|}
\hline City & Public building & Residential building \\
\hline Harbin & $\begin{array}{l}1 \mathrm{~mm} \text { cement }+70 \mathrm{~mm} \text { EPS }+20 \mathrm{~mm} \\
\text { cement mortar }+200 \mathrm{~mm} \text { slag hollow brick } \\
+20 \mathrm{~mm} \text { polymer mortar }\end{array}$ & $\begin{array}{l}1 \mathrm{~mm} \text { alkali-resistant fiberglass crack-proof } \\
\text { mortar }+70 \mathrm{~mm} \text { EPS }+20 \mathrm{~mm} \text { cement grout } \\
+350 \mathrm{~mm} \text { clay porous brick }+20 \mathrm{~mm} \\
\text { polymer mortar }\end{array}$ \\
\hline Changchun & $\begin{array}{l}65 \mathrm{~mm} \text { slag concrete polystyrene board }+ \\
190 \mathrm{~mm} \text { slag hollow brick }+20 \mathrm{~mm} \text { lime } \\
\text { mortar }\end{array}$ & $\begin{array}{l}1 \mathrm{~mm} \text { alkali-resistant fiberglass crack-proof } \\
\text { mortar }+60 \mathrm{~mm} \text { EPS }+20 \mathrm{~mm} \text { cement grout } \\
\text { mortar }\end{array}$ \\
\hline Beijing & $\begin{array}{l}12 \mathrm{~mm} \text { EPS thermal insulation mortar }+28 \\
\mathrm{~mm} \text { rigid polyurethane foam }+190 \mathrm{~mm} \\
\text { concrete hollow block }+20 \mathrm{~mm} \text { lime mortar }\end{array}$ & $\begin{array}{l}20 \mathrm{~mm} \text { special finishing mortar and coatings } \\
+65 \mathrm{~mm} \text { cement polystyrene board }+160 \\
\mathrm{~mm} \text { aerated concrete and foam concrete }+ \\
20 \mathrm{~mm} \text { lime cement mortar }\end{array}$ \\
\hline Chongqing & $\begin{array}{l}4 \mathrm{~mm} \text { fiberglass cloth with anti-crack mortar } \\
+42 \mathrm{~mm} \text { bonding powder expanded }\end{array}$ & $\begin{array}{l}5 \mathrm{~mm} \text { alkali-resistant fiberglass crack-proof } \\
\text { mortar }+20 \mathrm{~mm} \text { bonding powder expanded }\end{array}$ \\
\hline
\end{tabular}




\section{Do not use graphics embedded in this document}

\begin{tabular}{|l|l|l|}
\hline & $\begin{array}{l}\text { polystyrene granule insulating material + } \\
200 \mathrm{~mm} \text { reinforced concrete }+20 \mathrm{~mm} \text { lime } \\
\text { cement mortar }\end{array}$ & $\begin{array}{l}\text { polystyrene granule insulating material + 260 } \\
\text { mm reinforced concrete }+20 \mathrm{~mm} \text { lime } \\
\text { cement mortar }\end{array}$ \\
\hline Wuhan & Same as Chongqing & Same as Chongqing \\
\hline Shanghai & Same as Chongqing & Same as Chongqing \\
\hline Guangzhou & $\begin{array}{l}6 \mathrm{~mm} \text { gypsum board }+14 \mathrm{~mm} \text { EPS }+250 \\
\text { mm reinforced concrete }+25 \mathrm{~mm} \text { lime } \\
\text { cement mortar }\end{array}$ & Same as Chongqing \\
\hline \multicolumn{2}{|l}{} \\
\hline
\end{tabular}




\section{Do not use graphics embedded in this document}

\section{Cool roof savings}

Table D-1. Annual heating and cooling loads in simulated office building at roof albedo 0.2 , and savings upon increasing roof albedo to 0.6 or 0.8 .

\begin{tabular}{|c|c|c|c|c|c|c|c|c|c|}
\hline & $\begin{array}{l}\text { Heating } \\
\text { load / } \\
\text { cooling load }\end{array}$ & $\begin{array}{l}\text { Heating } \\
\text { load } \\
(\rho=0.2) \\
{\left[k W h / m^{2}\right.} \\
\text { CRA] }\end{array}$ & $\begin{array}{l}\text { Heating } \\
\text { load } \\
\text { savings } \\
(\rho=0.6) \\
{\left[\mathrm{kWh} / \mathrm{m}^{2}\right.} \\
\text { CRA] }\end{array}$ & $\begin{array}{l}\text { Heating } \\
\text { load } \\
\text { savings } \\
(\rho=0.8) \\
{\left[\mathrm{kWh} / \mathrm{m}^{2}\right.} \\
\text { CRA] }\end{array}$ & $\begin{array}{l}\text { Cooling } \\
\text { load } \\
(\rho=0.2) \\
{\left[k W h / m^{2}\right.} \\
\text { CRA] }\end{array}$ & $\begin{array}{l}\text { Cooling } \\
\text { load } \\
\text { savings } \\
(\rho=0.6) \\
{\left[\mathrm{kWh} / \mathrm{m}^{2}\right.} \\
\text { CRA] }\end{array}$ & $\begin{array}{l}\text { Cooling } \\
\text { load } \\
\text { savings } \\
(\rho=0.8) \\
{\left[\mathrm{kWh} / \mathrm{m}^{2}\right.} \\
\text { CRA] }\end{array}$ & $\begin{array}{l}\text { Conditioning } \\
\text { load savings } \\
(\rho=0.6) \\
{\left[\mathrm{kWh} / \mathrm{m}^{2}\right.} \\
\text { CRA] }\end{array}$ & $\begin{array}{l}\text { Conditioning } \\
\text { load savings } \\
(\rho=0.8) \\
{\left[\mathrm{kWh} / \mathrm{m}^{2}\right.} \\
\text { CRA] }\end{array}$ \\
\hline Harbin & 11 & 257.172 & -3.683 & -5.540 & 22.899 & 2.283 & 3.369 & -1.400 & -2.171 \\
\hline Changchun & 7.5 & 181.072 & -4.162 & -6.318 & 24.260 & 2.633 & 3.902 & -1.529 & -2.416 \\
\hline Beijing & 1.7 & 102.067 & -4.094 & -6.225 & 58.832 & 5.452 & 8.143 & 1.359 & 1.919 \\
\hline Chongqing & 0.60 & 45.889 & -1.033 & -1.827 & 75.852 & 5.236 & 7.788 & 4.203 & 5.961 \\
\hline Shanghai & 0.91 & 69.123 & -3.256 & -5.306 & 76.286 & 6.944 & 10.219 & 3.688 & 4.912 \\
\hline Wuhan & 0.64 & 66.086 & -2.135 & -3.606 & 103.466 & 8.175 & 12.110 & 6.040 & 8.504 \\
\hline Guangzhou & 0.090 & 13.877 & -1.909 & -2.935 & 153.906 & 12.434 & 18.718 & 10.525 & 15.784 \\
\hline
\end{tabular}

Table D-3. Annual heating and cooling loads in simulated residential building at roof albedo 0.2 , and savings upon increasing roof albedo to 0.6 or 0.8 .

\begin{tabular}{|c|c|c|c|c|c|c|c|c|c|}
\hline & $\begin{array}{l}\text { Heating } \\
\text { load / } \\
\text { cooling load }\end{array}$ & $\begin{array}{l}\text { Heating } \\
\text { load } \\
(\rho=0.2) \\
{\left[\mathrm{kWh} / \mathrm{m}^{2}\right.} \\
\text { CRA] }\end{array}$ & $\begin{array}{l}\text { Heating } \\
\text { load } \\
\text { savings } \\
(\rho=0.6) \\
{\left[\mathrm{kWh} / \mathrm{m}^{2}\right.} \\
\text { CRA] }\end{array}$ & $\begin{array}{l}\text { Heating } \\
\text { load } \\
\text { savings } \\
(\rho=0.8) \\
{\left[\mathrm{kWh} / \mathrm{m}^{2}\right.} \\
\text { CRA] }\end{array}$ & $\begin{array}{l}\text { Cooling } \\
\text { load } \\
(\rho=0.2) \\
{\left[\mathrm{kWh} / \mathrm{m}^{2}\right.} \\
\text { CRA] }\end{array}$ & $\begin{array}{l}\text { Cooling } \\
\text { load } \\
\text { savings } \\
(\rho=0.6) \\
{\left[\mathrm{kWh} / \mathrm{m}^{2}\right.} \\
\text { CRA] }\end{array}$ & $\begin{array}{l}\text { Cooling } \\
\text { load } \\
\text { savings } \\
(\rho=0.8) \\
{\left[\mathrm{kWh} / \mathrm{m}^{2}\right.} \\
\text { CRA] }\end{array}$ & $\begin{array}{l}\text { Conditioning } \\
\text { load savings } \\
(\rho=0.6) \\
{\left[\mathrm{kWh} / \mathrm{m}^{2}\right.} \\
\text { CRA] }\end{array}$ & $\begin{array}{l}\text { Conditioning } \\
\text { load savings } \\
(\rho=0.8) \\
{\left[\mathrm{kWh} / \mathrm{m}^{2}\right.} \\
\text { CRA] }\end{array}$ \\
\hline Harbin & - & 115.126 & -1.720 & -2.599 & - & - & - & -1.720 & -2.599 \\
\hline Changchun & - & 117.058 & -2.202 & -3.333 & - & - & - & -2.202 & -3.333 \\
\hline Beijing & 1.3 & 63.400 & -2.629 & -3.990 & 48.632 & 3.480 & 5.199 & 0.851 & 1.209 \\
\hline Chongqing & 0.78 & 52.185 & -1.790 & -2.709 & 66.543 & 5.523 & 8.263 & 3.733 & 5.553 \\
\hline Shanghai & 1.2 & 71.309 & -4.724 & -7.202 & 57.535 & 6.672 & 9.891 & 1.948 & 2.690 \\
\hline Wuhan & 0.68 & 72.551 & -3.384 & -5.122 & 106.640 & 8.971 & 13.456 & 5.587 & 8.334 \\
\hline
\end{tabular}


Do not use graphics embedded in this document

\begin{tabular}{|l|l|l|l|l|l|l|l|l|l|}
\hline Guangzhou & 0.0072 & 1.014 & -0.201 & -0.315 & 141.486 & 10.903 & 16.355 & 10.702 & 16.040 \\
\hline
\end{tabular}




\section{Do not use graphics embedded in this document}

Table D-5. Annual heating and cooling site and source energy savings in simulated office building upon increasing roof albedo to 0.6 from 0.2 .

\begin{tabular}{|c|c|c|c|c|c|}
\hline & $\begin{array}{l}\text { Heating site } \\
\text { energy } \\
\text { savings } \\
{\left[\mathrm{kWh} / \mathrm{m}^{2} \mathrm{CRA}\right]}\end{array}$ & $\begin{array}{l}\text { Cooling site } \\
\text { energy } \\
\text { savings } \\
{\left[\mathrm{kWh} / \mathrm{m}^{2} \mathrm{CRA}\right]}\end{array}$ & $\begin{array}{l}\text { Heating } \\
\text { source energy } \\
\text { savings } \\
{\left[\mathrm{kWh} / \mathrm{m}^{2} \mathrm{CRA}\right]}\end{array}$ & $\begin{array}{l}\text { Cooling } \\
\text { source energy } \\
\text { savings } \\
{\left[\mathrm{kWh} / \mathrm{m}^{2} \mathrm{CRA}\right]}\end{array}$ & $\begin{array}{l}\text { Conditioning } \\
\text { source energy } \\
\text { savings } \\
{\left[\mathrm{kWh} / \mathrm{m}^{2} \mathrm{CRA}\right]}\end{array}$ \\
\hline Harbin & -5.26 & 0.692 & -5.52 & 2.19 & -3.33 \\
\hline Changchun & -5.95 & 0.798 & -6.24 & 2.53 & -3.72 \\
\hline Beijing & -5.85 & 1.65 & -6.14 & 5.23 & -0.908 \\
\hline Chongqing & -0.295 & 1.59 & -0.935 & 5.03 & 4.09 \\
\hline Shanghai & -0.930 & 2.10 & -2.95 & 6.66 & 3.72 \\
\hline Wuhan & -0.610 & 2.48 & -1.93 & 7.85 & 5.91 \\
\hline Guangzhou & -0.546 & 3.77 & -1.73 & 11.9 & 10.2 \\
\hline
\end{tabular}

Table D-7. Annual heating and cooling site and source energy savings in simulated residential building upon increasing roof albedo to 0.6 from 0.2 .

\begin{tabular}{|c|c|c|c|c|c|}
\hline & $\begin{array}{l}\text { Heating site } \\
\text { energy } \\
\text { savings } \\
{\left[\mathrm{kWh} / \mathrm{m}^{2} \mathrm{CRA}\right]}\end{array}$ & $\begin{array}{l}\text { Cooling site } \\
\text { energy } \\
\text { savings } \\
{\left[\mathrm{kWh} / \mathrm{m}^{2} \mathrm{CRA}\right]}\end{array}$ & $\begin{array}{l}\text { Heating source } \\
\text { energy savings } \\
{\left[\mathrm{kWh} / \mathrm{m}^{2} \mathrm{CRA}\right]}\end{array}$ & $\begin{array}{l}\text { Cooling } \\
\text { source energy } \\
\text { savings } \\
{\left[\mathrm{kWh} / \mathrm{m}^{2} \mathrm{CRA}\right]}\end{array}$ & $\begin{array}{l}\text { Conditioning } \\
\text { source energy } \\
\text { savings } \\
{\left[\mathrm{kWh} / \mathrm{m}^{2} \text { CRA] }\right.}\end{array}$ \\
\hline Harbin & -2.46 & 0.000 & -2.58 & 0.000 & -2.58 \\
\hline Changchun & -3.15 & 0.000 & -3.30 & 0.000 & -3.30 \\
\hline Beijing & -3.76 & 1.05 & -3.94 & 3.34 & -0.604 \\
\hline Chongqing & -0.511 & 1.67 & -1.62 & 5.30 & 3.68 \\
\hline Shanghai & -1.35 & 2.02 & -4.27 & 6.40 & 2.13 \\
\hline Wuhan & -0.967 & 2.72 & -3.06 & 8.61 & 5.55 \\
\hline Guangzhou & -0.057 & 3.30 & -0.182 & 10.5 & 10.3 \\
\hline
\end{tabular}

Table D-9. Annual energy cost and emission savings in simulated office building upon increasing roof albedo to 0.6 from 0.2 .

\begin{tabular}{|l|l|l|l|c|}
\hline & $\begin{array}{l}\text { Energy cost } \\
\text { saving } \\
{[\text { RMB/m }} \\
\text { CRA] }\end{array}$ & $\begin{array}{l}\mathbf{C O}_{2} \text { savings } \\
{\left[\mathbf{k g} / \mathbf{m}^{2} \text { CRA] }\right.}\end{array}$ & $\begin{array}{l}\mathbf{N O}_{\mathbf{x}} \text { savings } \\
{[\mathbf{g} / \mathbf{m} \text { 2 CRA] }}\end{array}$ & $\begin{array}{l}\mathbf{S O}_{2} \\
\text { savings } \\
{\left[\mathbf{g} / \mathbf{m}^{2} \text { CRA] }\right.}\end{array}$ \\
\hline Harbin & -0.359 & -0.891 & 0.809 & -9.42 \\
\hline Changchun & 0.744 & -0.988 & 1.01 & -10.5 \\
\hline Beijing & 1.30 & -0.086 & 4.09 & 1.24 \\
\hline Chongqing & 1.06 & 1.43 & 7.75 & 18.8 \\
\hline Shanghai & 0.996 & 1.08 & 5.09 & 9.39 \\
\hline Wuhan & 1.80 & 2.06 & 11.2 & 27.2 \\
\hline Guangzhou & 3.03 & 3.35 & 13.2 & 32.6 \\
\hline
\end{tabular}


Table D-6. Annual energy cost and emission savings in simulated residential building upon increasing roof albedo to 0.6 from 0.2 .

\begin{tabular}{|l|c|c|c|c|}
\hline & $\begin{array}{l}\text { Energy cost } \\
\text { saving } \\
{[\text { [RMB/m }} \\
\text { CRA] }\end{array}$ & $\begin{array}{l}\mathbf{C O}_{2} \text { savings } \\
{\left[\mathbf{k g} / \mathbf{m}^{2} \text { CRA] }\right.}\end{array}$ & $\begin{array}{l}\mathbf{N O}_{\mathbf{x}} \text { savings } \\
{[\mathbf{g} / \mathbf{m} \text { 2 CRA }]}\end{array}$ & $\begin{array}{l}\mathbf{S O}_{2} \\
\text { savings } \\
{\left[\mathbf{g} / \mathbf{m}^{2} \text { CRA] }\right.}\end{array}$ \\
\hline Harbin & -0.396 & -0.809 & -1.60 & -6.73 \\
\hline Changchun & 0.000 & -1.04 & -2.04 & -8.62 \\
\hline Beijing & 0.506 & -0.062 & 2.60 & 0.725 \\
\hline Chongqing & 0.596 & 1.28 & 6.97 & 16.9 \\
\hline Shanghai & 0.413 & 0.616 & 2.91 & 5.38 \\
\hline Wuhan & 0.991 & 1.94 & 10.5 & 25.5 \\
\hline Guangzhou & 1.97 & 3.37 & 13.3 & 32.8 \\
\hline
\end{tabular}

